\title{
Structure and crustal balance of the Herald Arch and Hope Basin in the Chukchi Sea, Alaska
}

\author{
D. Alex Patthoff \\ West Virginia University
}

Follow this and additional works at: https://researchrepository.wvu.edu/etd

\section{Recommended Citation}

Patthoff, D. Alex, "Structure and crustal balance of the Herald Arch and Hope Basin in the Chukchi Sea, Alaska" (2008). Graduate Theses, Dissertations, and Problem Reports. 2612.

https://researchrepository.wvu.edu/etd/2612

This Thesis is protected by copyright and/or related rights. It has been brought to you by the The Research Repository @ WVU with permission from the rights-holder(s). You are free to use this Thesis in any way that is permitted by the copyright and related rights legislation that applies to your use. For other uses you must obtain permission from the rights-holder(s) directly, unless additional rights are indicated by a Creative Commons license in the record and/ or on the work itself. This Thesis has been accepted for inclusion in WVU Graduate Theses, Dissertations, and Problem Reports collection by an authorized administrator of The Research Repository @ WVU. For more information, please contact researchrepository@mail.wvu.edu. 


\title{
Structure and Crustal Balance of the Herald Arch and Hope Basin in the Chukchi Sea, Alaska
}

\author{
D. Alex Patthoff \\ Thesis submitted to the \\ Eberly College of Arts and Sciences \\ at West Virginia University \\ in partial fulfillment of the requirements \\ for the degree of \\ Master of Science \\ in \\ Geology \\ Committee Members: \\ Jaime Toro, Ph.D. (Chair) \\ Tom Wilson, Ph.D. \\ David Oldham, Ph.D. \\ Department of Geology and Geography \\ Morgantown, West Virginia \\ 2008
}

Key Words: Herald Arch, Herald Thrust, Hope Basin, Colville Basin 


\section{Abstract \\ Structure and Crustal Balance of the Herald Arch and Hope Basin in the Chukchi Sea, Alaska}

\section{Alex Patthoff}

The Herald Arch is a structural high bounded by the Herald Thrust fault to the northeast and by a normal, or possibly strike-slip, fault to the southwest in the Chukchi Sea, off the northwest coast of Alaska. The thrust continues for approximately 60 kilometers from the northwest tip of the Lisburne Peninsula into the Chukchi Sea. Its dip varies from nearly 60 degrees in the east, to 20 degrees in the west before terminating on the available seismic data. Closer to the shore, the detachment of the Herald Thrust occurs at the edge of a Devonian rift basin containing the Franklinian Sequence. Moving towards the northwest, the rift diminishes along with the detachment of the Herald Thrust. Northeast of the Herald Thrust in the Colville Basin, the anticlines and thrust faults of the Brookian layers diminish in magnitude and displacement from the Lisburne Peninsula to the northwest. The depth to the reflection Moho decreases from approximately $37 \mathrm{~km}$ beneath the Colville Basin to $28 \mathrm{~km}$ under the Hope Basin to the south. Estimates for the amount of extension required to produce the present day crustal thickness are at least $20 \%$ less than the amount of Tertiary stretching that has been documented by restoration of supracrustal normal faults. The thinning of the crust could be attributed to differential spreading where the upper crust was stretched less then the lower crust and mantle, or due to and older, mid Cretaceous, extensional event that has gone unrecognized on the seismic data. A magnetic high that corresponds closely to the Herald Arch could be evidence of magmatic material brought up during the midCretaceous spreading event. 


\section{ACKNOWLEDGEMENTS}

I extend my sincere thanks to Dr. Jaime Toro for the benefit of his insights and continued support throughout this study. I am also grateful to Dr. David Oldham for helping me complete this work and to Dr. Thomas Wilson for his assistance with seismic data processing and gravity and magnetic interpretations.

Thank you to the United States Geological Survey, Western Geco and Stanford University for providing the data included in this study.

Many thanks to my parents, Deb and Don Patthoff and to all of my family, especially Erica, Adria, Chelsea, Ryan and Aaron, for their continued support. Lastly, to my wife Abby, thank you for your patience and endless encouragement during the completion of this work. 


\section{TABLE OF CONTENTS}

TABLE OF CONTENTS ........................................................................................... iv

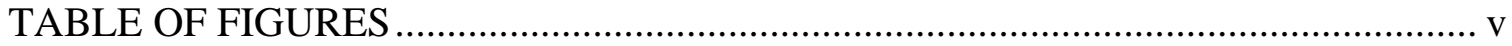

LIST OF TABLES ............................................................................................. vii

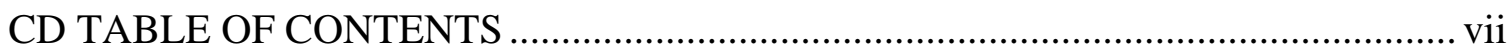

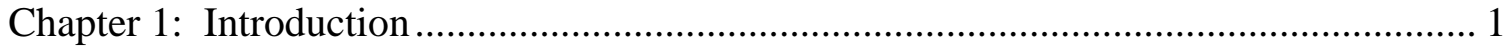

Chapter 2: Theoretical Framework ………………………....................................... 7

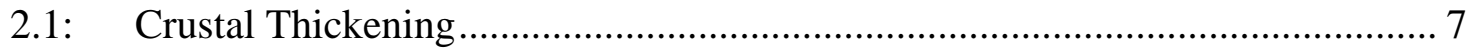

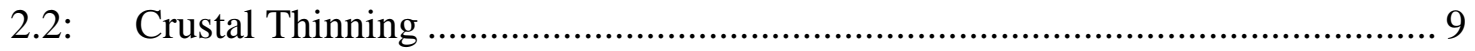

2.3: Differential Stretching …………………………............................................ 10

Chapter 3: Geologic History and Setting.................................................................... 13

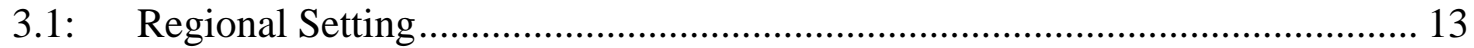

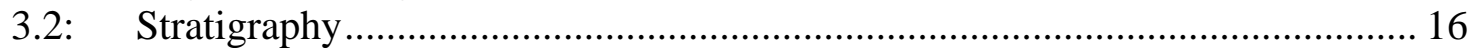

3.2.1: Pre-Mississippian/Franklinian/Acoustic Basement ...................................... 23

3.2.2: Ellesmerian Sequence .............................................................................. 24

3.2.3: Rift Sequence ………………………………………………………..... 26

3.2.4: Brookian Sequence .................................................................................. 27

3.3: Geological History Overview …………………............................................... 27

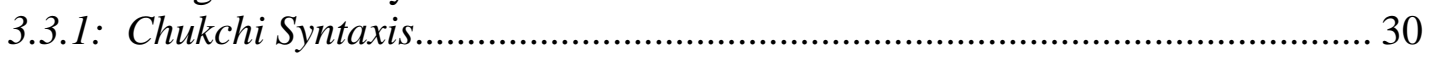

3.3.2: Herald Arch ........................................................................................... 33

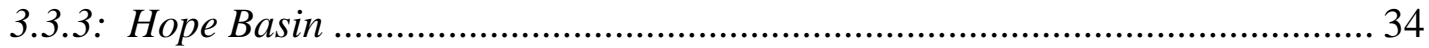

Chapter 4: Geophysical Investigations ................................................................... 36

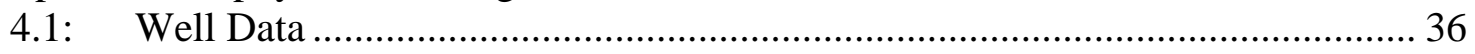

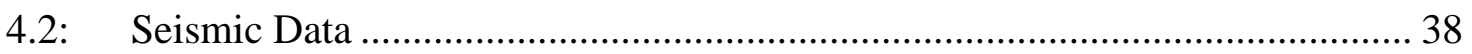

4.2.1: WesternGeco Seismic Data ..................................................................... 38

4.2.2: USGS Seismic Data …………………………...................................... 39

4.2.3: Stanford and USGS Deep Crustal Lines...................................................... 40

4.3: $\quad$ Additional Seismic Processing …………….................................................... 43

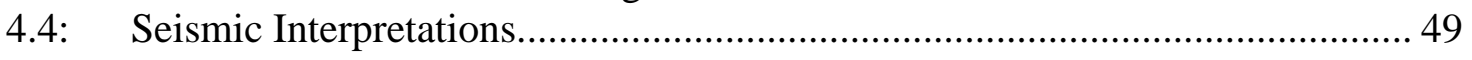

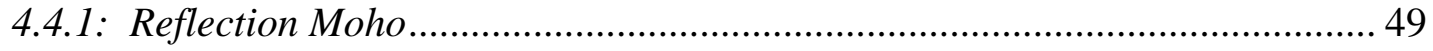

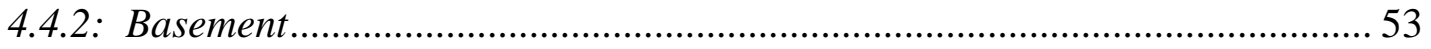

4.4.3: Permian and Lower Cretaceous Unconformities .......................................... 59

4.4.4: Brookian Horizons and Angular Unconformity .............................................. 61

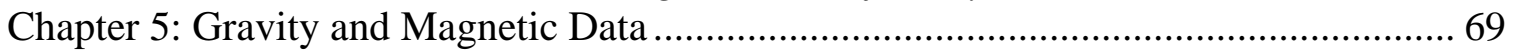

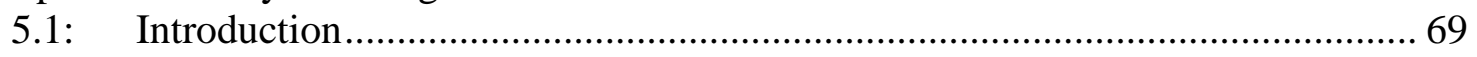

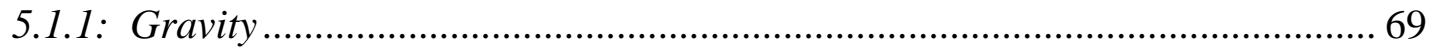

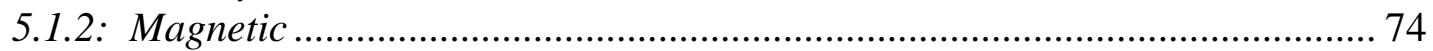

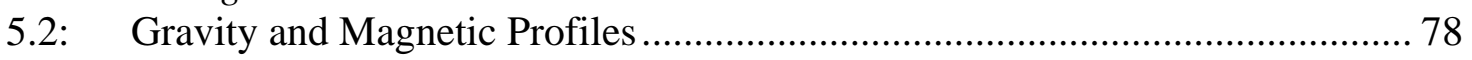

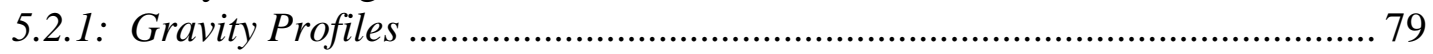

5.2.2: Magnetic Profiles ..................................................................................... 87

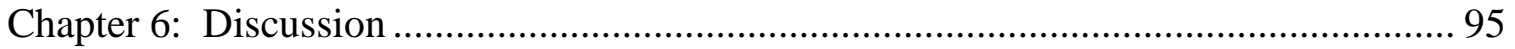

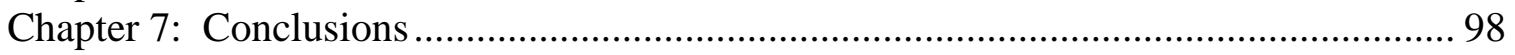

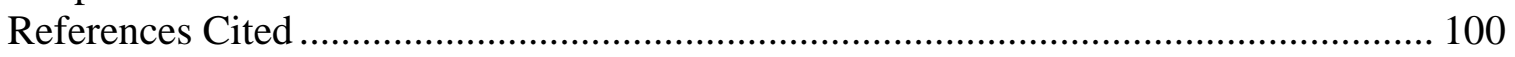

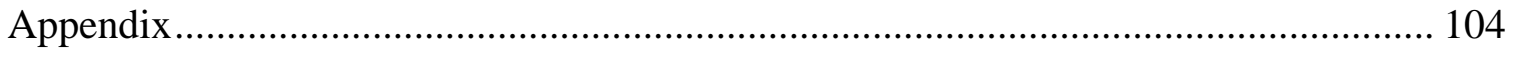




\section{LIST OF FIGURES}

Figure 1: Bathymetry and topography map .................................... 4

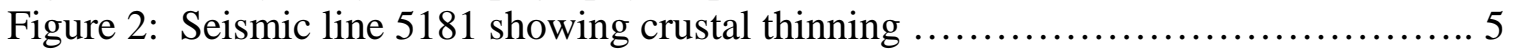

Figure 3: Extent of the Herald Thrust and Arch before this study $\ldots \ldots \ldots \ldots \ldots \ldots \ldots \ldots . \ldots$

Figure 4: Cartoon demonstrating the concept of orogenic collapse $\ldots \ldots \ldots \ldots \ldots \ldots \ldots \ldots . \ldots \ldots$

Figure 5: Generalized model for "steer's head" basin ............................ 12

Figure 6: Boundary of the Arctic Alaska Chukotka Plate and Arc and displaced

Terrains ............................................................... 15

Figure 7: Stratigraphic column of northwest Alaska ............................ 18

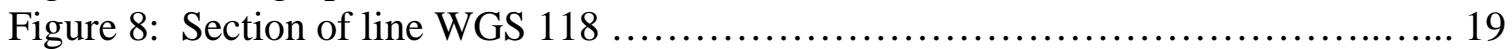

Figure 9A: Section of USGS-Stanford deep crustal line .......................................... 20

Figure 9B: Uninterpreted USGS-Stanford deep crustal line ....................... 21

Figure 10: Location map showing seismic data, and onland geology ................. 22

Figure 11: Geological history of the Hanna Trough and Chukchi Shelf ................ 31

Figure 12: Geological history of the Lisburne Hills and Herald Arch ................. 35

Figure 13: Locations of wells and velocity-depth refraction survey ................. 37

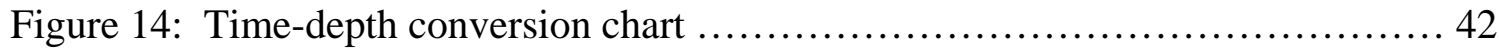

Figure 15: Frequency spectrum for shot points $27000-27850$ on USGS $5181 \ldots \ldots \ldots . .45$

Figure 16: Frequency spectrum for shot points 30000-30850 on USGS 5181 ........ 45

Figure 17: Original display between shot points $27000-27850$ on USGS $5181 \ldots \ldots . . .47$

Figure 18: Processed display between shot points 27000-27850 on USGS 5181 ...... 47

Figure 19: Original display between shot points 30000-30850 on USGS $5181 \ldots \ldots . . .48$

Figure 20: Processed display between shot points 27000-27850 on USGS 5181 ....... 48

Figure 21: Eastern section of USGS deep crustal line 5181 ...................... 51

Figure 22: Two-way time structure map of the Moho .......................... 52

Figure 23: Uninterpreted and interpreted segment of WGS $116 \ldots \ldots \ldots \ldots \ldots \ldots \ldots \ldots \ldots$

Figure 24: Two-way time structure map of the basement ........................ 55

Figure 25: Location map of seismic profiles for figures 23, 26, 28 and $30 \ldots \ldots \ldots \ldots . \ldots$

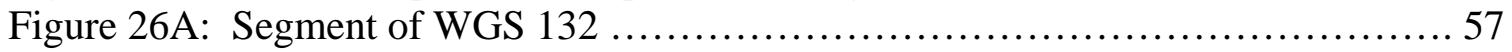

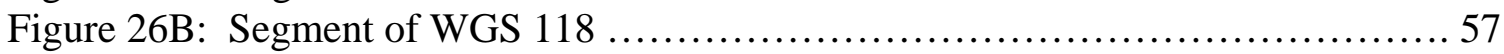

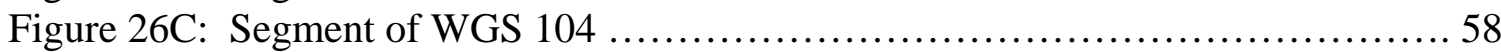

Figure 27: Two-way time structure map of Lower Cretaceous Unconformity .......... 60

Figure 28: Example of a seismic mis-tie between 104 and 109 ...................... 64

Figure 29: Two-way time structure map of the Brookian 1 horizon ................... 65

Figure 30: Uninterpreted and interpreted segment of WGS $102 \ldots \ldots \ldots \ldots \ldots \ldots \ldots \ldots . \ldots 6$

Figure 31: Landsat and Brookian 1 two-way time structure map .................... 67

Figure 32: Gravity map with overlays of the interpreted thrusts ................... 71

Figure 33: Gravity map with overlays of the two-way time depth to the Moho ....... 72

Figure 34: Gravity map with overlays of the two-way time depth to the basement .... 73

Figure 35: Magnetic map with overlays of the interpreted thrusts ................. 75

Figure 36: Magnetic map with overlays of the two-way time depth to the Moho ...... 76

Figure 37: Magnetic map with overlays of the two-way time depth to the basement ... 77

Figure 38: Gravity map showing the locations of the profiles in figures $39-42 \ldots \ldots \ldots 81$

Figure 39: Comparison of USGS 5181 with a coincident gravity profile ............... 82

Figure 40: Comparison of WGS 108 with a coincident gravity profile $\ldots \ldots \ldots \ldots \ldots \ldots . . . .83$ 
Figure 41: Comparison of WGS 104 with a coincident gravity profile ............... 84

Figure 42: Comparison of WGS 111 with a coincident gravity profile ................ 85

Figure 43: Magnetic map showing the locations of the profiles in figures 44-47 ...... 89

Figure 44: Comparison of USGS 5181 with a coincident gravity and magnetic profile.. 90

Figure 45: Comparison of WGS 108 with a coincident gravity and magnetic profile ... 91

Figure 46: Comparison of WGS 104 with a coincident gravity and magnetic profile .. 92

Figure 47: Comparison of WGS 111 with a coincident gravity and magnetic profile .. 93 


\section{LIST OF TABLES}

Table 1A: Percent shortening due to all faults except Herald Thrust ................. 68

Table 1B: Percent shortening due to the Herald Thrust .......................... 69

Table 2: Estimated maximum depths to anomalies causing gravity anomalies ....... 86

Table 3: Estimated maximum depths to anomalies causing magnetic anomalies ...... 94

\section{TABLE OF CONTENTS}

1) Plates 1, 2 and 3 


\section{Chapter 1: Introduction}

The Herald Arch is a band of basement rock, approximately $2.5 \mathrm{~km}$ thick, which forms the central segment of a curved structural belt located off the northwest coast of Alaska beneath the Chukchi Sea (figure 1) (Moore et al., 2002). The arch is most easily identified by its base which appears as a consistently strong, gently curving basement reflector lying about 2 seconds below the sea floor $(2-3 \mathrm{~km})$ (figure 2$)$. To the northwest, this structure continues beneath the sea before reaching Wrangel Island, Russia and possibly continuing beyond to the west. To the south of the Herald Arch, the structure continues on land as the Lisburne Hills fold and thrust belt (Moore et al., 2002) (figure 3). The eastern end of the structure belt terminates in Alaska at the western edge of the Brooks Range in a region known as the Chukchi Syntaxis. Here, the structural trends change abruptly from north-south for the Herald Arch and Lisburne Hills to east-west for the Brooks Range (figures 1 and 3) (Amato et al. 2002).

North of the Herald Arch is the Hanna Trough, the western portion of the larger North Slope Basin, overlain by the Colville Basin, a Cretaceous and younger foreland basin of the Brooks Range (figure 3). The thick (2-5 km) sedimentary section of the Colville Basin was derived from a source area that is now beneath the Tertiary Hope Basin (figure 1). The thickness of the Colville basin strata indicates there was “significant topography, possibly over three kilometers” (Klemperer et al., 2002), created during the Brookian Orogeny. I calculated that the elevated terrain requires the presence of a crustal root of approximately $17 \mathrm{~km}$ to maintain simple isostatic equilibrium if the mountain range was at least $3 \mathrm{~km}$. The crustal root must have been later removed, 
possibly by extension and collapse, between the Late Cretaceous and Tertiary (Klemperer et al., 2002). The late Jurassic to Cretaceous rocks of the Colville Basin are cut by numerous thrusts with large amounts of displacement (Moore et al., 2002). North of the Herald Arch, I documented thrust displacements of up to 2000 meters as a result of a large amount of shortening in the mid to late Cretaceous. I estimate the minimum shortening to be over 40\% (19 km) for the offshore area and Moore et al. (2002) estimates at least $65 \%$ for the Lisburne Hills area.

The Herald Arch is bounded on the south by the extensional Hope Basin (figure 2). This Basin consists of Tertiary and younger units cut by numerous normal faults (Tolson, 1987). The basin is believed to have formed as a result of extension and the orogenic collapse of the Herald Arch during the Tertiary after compression ceased to be the dominant force in the area. Reconstructions of the extensional faults done by Elswick (2003) indicate a maximum stretching of $9 \%$ with other areas of the basin only experiencing about $1 \%$.

Between the Colville Basin and the Hope Basin, the reflection Moho observed in deep seismic lines thins from about 13 seconds ( $37 \mathrm{~km}$ ) to about 10 seconds (28 km) (figure 2) and begins in the area just below the Herald Arch. Relative to basement rock, the slower seismic velocity of the Hope Basin sediment cover means that the shorter twoway reflection time to the Moho represents a true thinning of the crust and not a velocity artifact (Klemperer et al., 2002). Due to the previous inferred topography, the thinning of the crust would have required more than $30 \%$ extension to produce the thin crust we see today (Klemperer et al., 2002). This is far less than the 9\% extension found by Elswick 
(2003). This paper explores the possible mechanisms for the additional required thinning of the crust: orogenic collapse, crustal thinning and/or differential stretching.

If a crustal root is present, it should appear on gravity data as a large gravity low. However, gravity data show only a minor gravity low where the Herald Arch and Hope Basin are located and modeling indicates a lack of a crustal root (Wolf et al., 2002). The tectonic process required to produce the observed crustal thinning has not been explained by the inferred geologic history of the Hope Basin, Herald Arch and Brooks Range orogeny.

A series of seismic lines were used to explore the nature of the structure of the region and to document the magnitude of crustal thinning. These lines provided shallow data to explore the Herald Arch in moderate detail, as well as deep reflections to map the depth to the reflection Moho. While the general quality of the lines was poor, it was possible to correlate some of the major shallow horizons throughout the area. These surveys were used in conjunction with gravity and magnetic surveys for more regional interpretations, as well as to provide independent verification for the crustal thickness. 


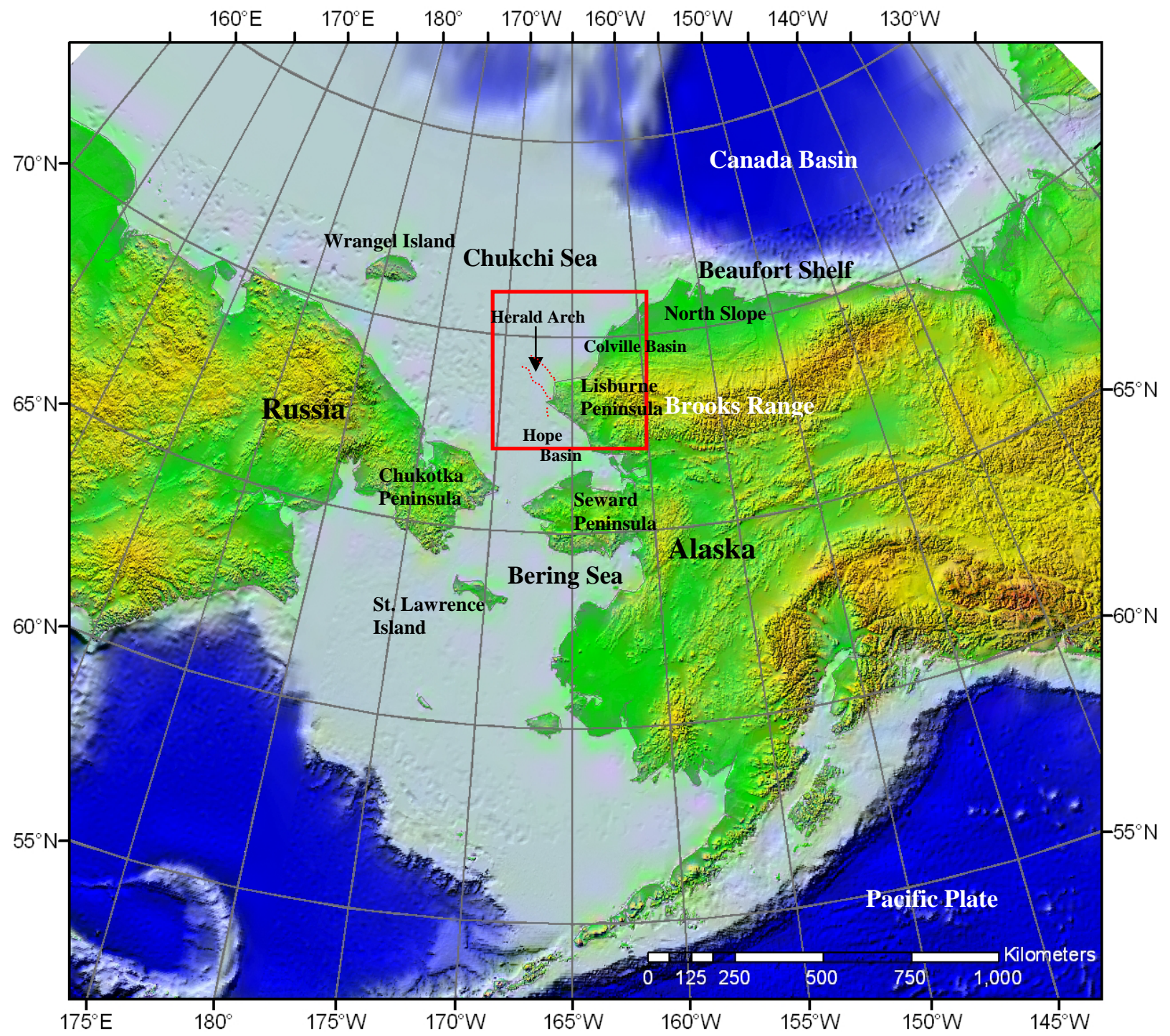

Figure 1: Bathymetry and topography map showing the study area (red box) and the mapped location of the Herald Arch. The arch lies between a thrust fault to the north and a normal or possible transverse fault to the south. Elevation data are from Smith and Sandwell (1997). 


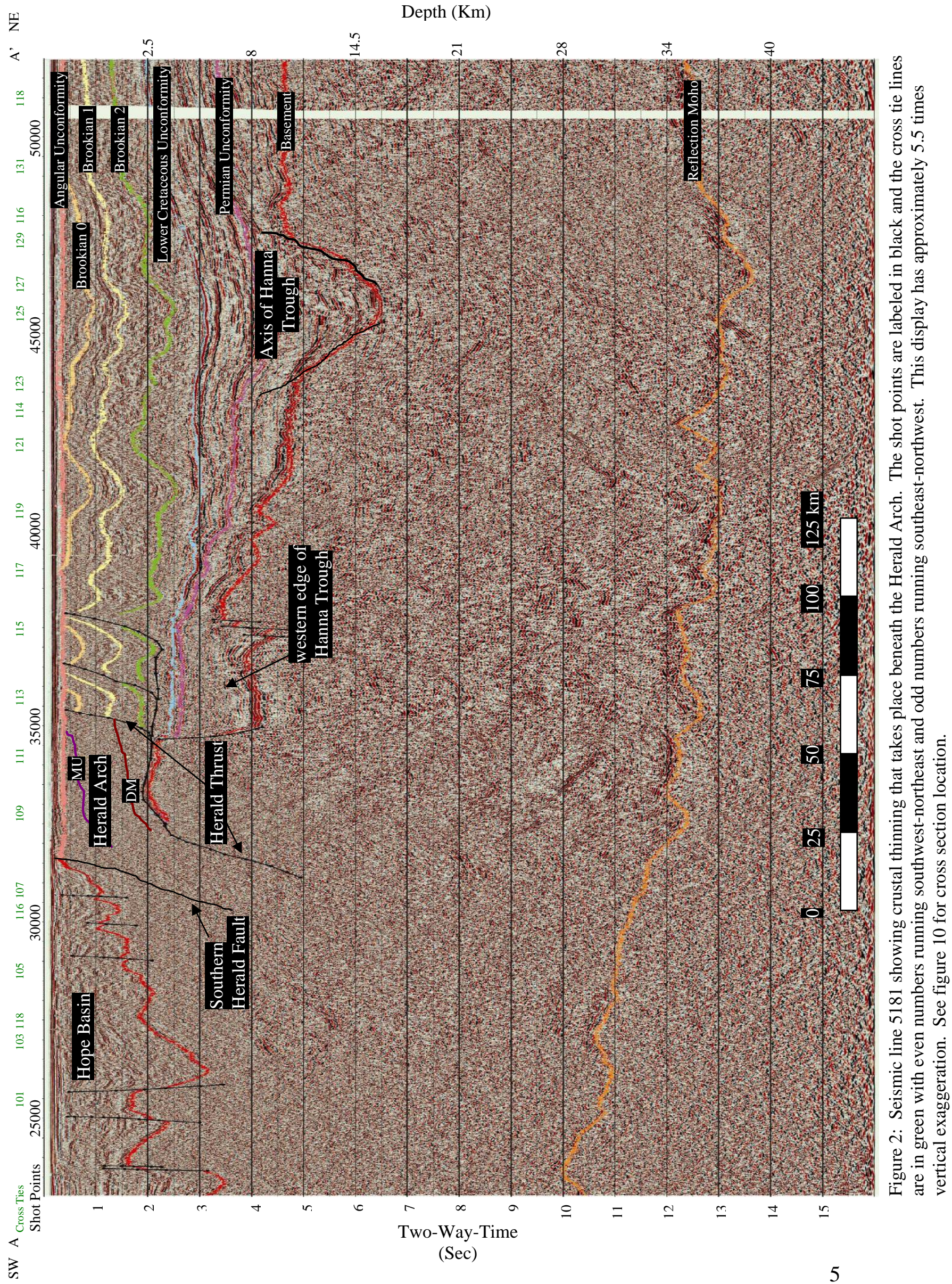




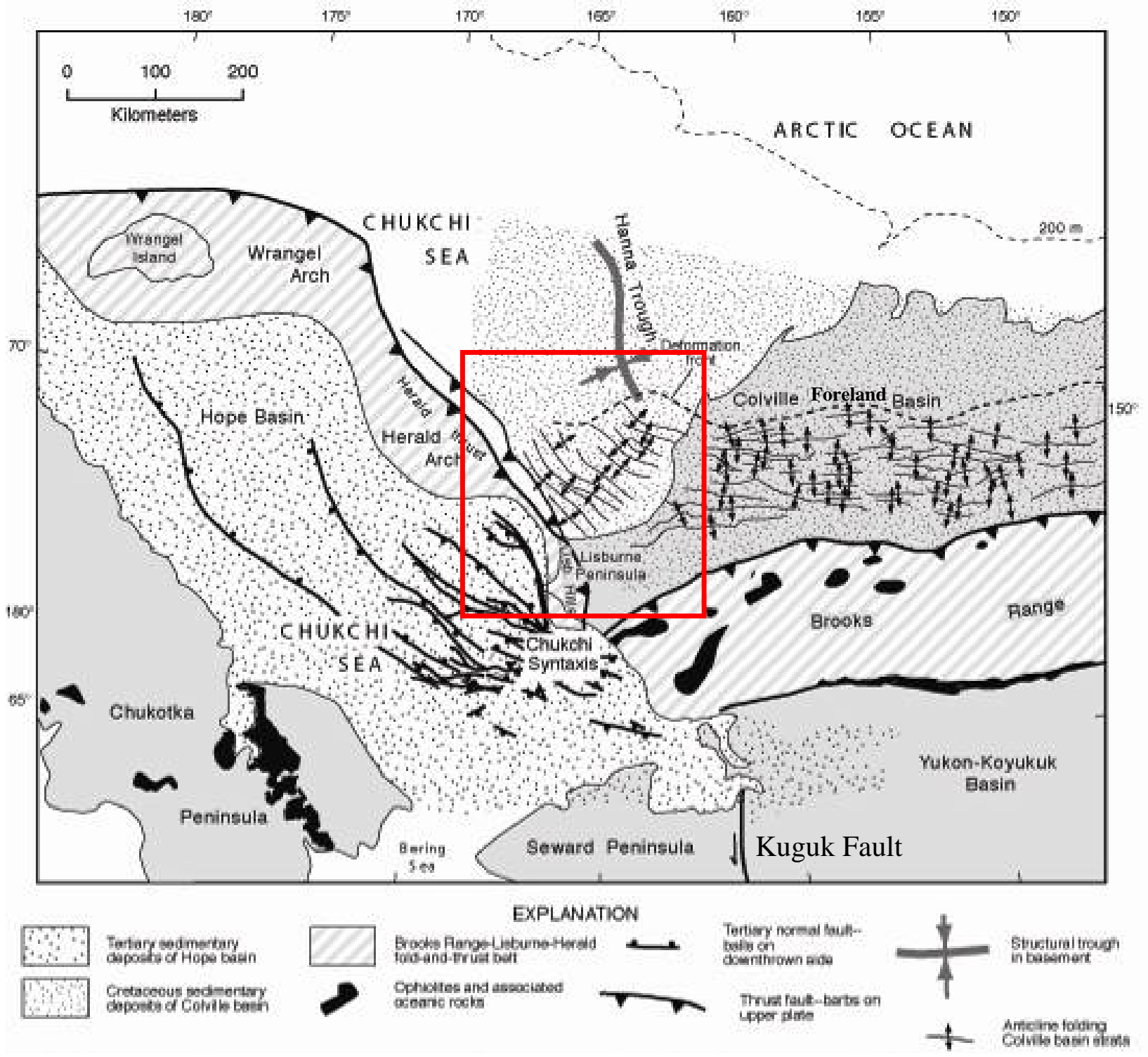

Figure 3: Map showing the extent of the Herald Thrust and arch before this study. Also shown are the locations of the Colville Basin and previously interpreted tectonic features (Modified from Amato et al., 2004). The red box indicates the study area. 


\section{Chapter 2: Theoretical Framework}

The main tectonic processes which shaped the lithosphere of northwest Alaska were compression and extension. Off the coast of present day Lisburne Peninsula, a series of compressional events related to the Brookian Orogeny during the late Cretaceous to early Tertiary caused a great crustal thickening (Amato et al., 2002), followed by Tertiary orogenic collapse during the formation of the Hope Basin (Tolson, 1987). These forces caused the thrust faults seen in the Colville Basin area and the normal faults seen in the Hope Basin. Along with these compressional and tensional forces, lateral motion is also seen in northern Alaska, in the form of strike-slip faults (Lallemant et al., 1998).

\section{1: Crustal Thickening}

Crustal thickening occurs in a compressional state, such as an orogenic event. As sections of crust are pushed together, the crust becomes shorter and the shortening must be accommodated by thickening in the crust and lithosphere. This thickening can create crust up to twice as thick as normal crust (Van Der Pluijm and Marshak, 2004) resulting in a mountain chain with a deep root projecting below the normal depth of surrounding crust (Kusznir et al., 1988). However, there is a limit to possible thickness of the crust. As the crustal root grows, it warms and becomes weaker at depth. The weakened rock begins to yield due to the overburden and gravity creating horizontal strain leading to extension and orogenic collapse (Van Der Pluijm and Marshak, 2004) (Figure 4). 


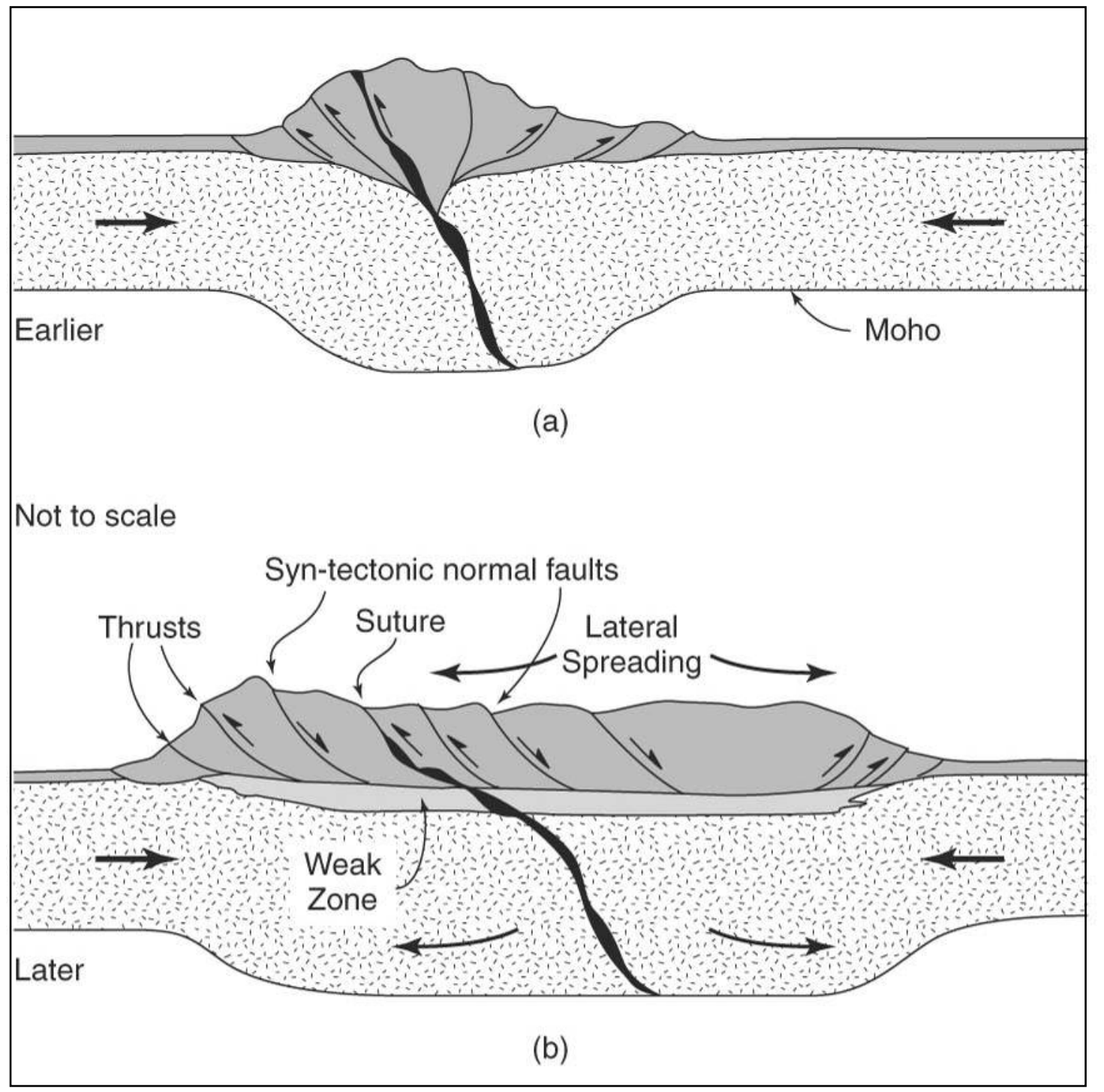

Figure 4: Cartoon demonstrating the concept of orogenic collapse. Part (a) is showing a cross section in the early stage of collision with the thickening of the crust. Part (b) shows the collapse of the orogenic belt due to the formation of normal faults near the surface and plastic flow occurring at depth. From Van Der Pluijm and Marshak (2004). 


\section{2: Crustal Thinning}

Lithospheric extension and orogenic collapse occur along orogenic belts for two main reasons. The first is because the elevated and thickened crust will contain many inhomogeneities, such as faults, leading to thinning by radial extension due to gravitational spreading through normal faulting (figure 4). When a mountain chain has been lifted to above about three kilometers, it will begin to collapse, even while the compressional forces are still active. This does not limit mountain chains to three kilometers because the compressional forces can still create uplift more quickly than the mountain can collapse. Even after the crust has returned to a normal thickness, weaknesses are still present, especially along the old contractional faults. This means that an orogenic event does not need to reach 3 kilometers in elevation before collapse can begin (Dewey, 1988).

The second means to crustal thinning is from convection. This process thins the thermal boundary conduction layer, low-velocity part of the continental lithosphere, causing weakening of the lithosphere and thinning of the crust. When the lithosphere is thickened due to horizontal shortening and compression, it becomes gravitationally unstable as the root is removed through convection within the mantle and a rise in the geothermal gradient occurs. As the thermal boundary layer is thinned, the overburden must also be removed to maintain isostatic equilibrium causing the structure to become weak. This weakened structure also contributes to extensional collapse through normal faulting by gravity. Previous faulting in an area will also contribute to the weakening of a structure creating areas where normal faults will be more likely form (Dewey, 1988). 


\section{3: Differential Stretching}

To account for the difference in required stretching to remove the crustal root, 30\%, (Klemperer et al., 2002) and the stretching observed by faulting of the upper crust, 1-9\% (Elswick, 2003), a differential stretching model is proposed. This difference in stretching has been observed in the Rhine graben where the upper crust experienced only $10 \%$ thinning but the lower crust could have been thinned by up to $50 \%$ (Zeyen et al., 1996).

Extension and orogenic collapse can lead to the formation of basins. One of the most common models is the "steer's head" geometry of basins (figure 5). This type of basin can be explained by the White and McKenzie (1988) model of differential stretching. In the first stage, the crust and lithosphere are stretched with the lithosphere stretching over a wider area than the crust. In the center of the basin, the stretching is greater for the upper crust but less for the lower crust and mantle. At the edges of the basin, the mantle experiences greater stretching than the upper crust. This initial stretching creates a thermal anomaly that decays over time causing subsidence and the second stage of the basin formation. The thermal subsidence creates onlap as the basin fills with sediment (figure 5) (White and McKenzie, 1988).

A differential stretching model must take into account volume conservation (Zeyen et al., 1996). To correct for the space issues, the total amount of stretching in the lithospheric mantle and the crust is actually equivalent but distributed differently. The size of the basin can be attributed to the velocities of lithospheric mantle and crustal extension. If the far-field velocities are smaller than the local extensional velocities in an area experiencing tension, a narrow basin with high shoulders will be produced. The 
extension is accommodated by these high shoulders adjacent to the rift. However, if the far-field velocities are similar to the maximum extensional velocity of the basin, a wide basin with no shoulders will be produced. The shoulders are not necessary because the extension is spread out over a larger area and results in a steer's head geometry (Zeyen, 1996). Given the very large size, $75,000 \mathrm{~km}^{2}$ (Tolson, 1987) of the Hope Basin and the lack of high shoulders in the region, it is more likely that the far field velocities are similar to the maximum local extensional velocities (Zeyen, 1996).

Another possible cause of differential stretching results when free movement of the upper crust is impeded but the lower crust and upper mantle are still able to slide beneath the upper crust. This is mostly likely to occur in an area where there is a bend in the fault system or if strike-slip faults turn to compressional zones. As the upper mantle slides below the crust, the lower crust is deformed and weakened. The weakened crust has a higher heat flow and is more ductile making it more susceptible to extensional, compressional or translational movements (Beaudoin, 1994). The change in strike of the Herald arch, compared to the Brooks Range, could be responsible for causing the upper crust to be impeded while allowing the lower crust to be weakened by the upper mantle sliding beneath. 


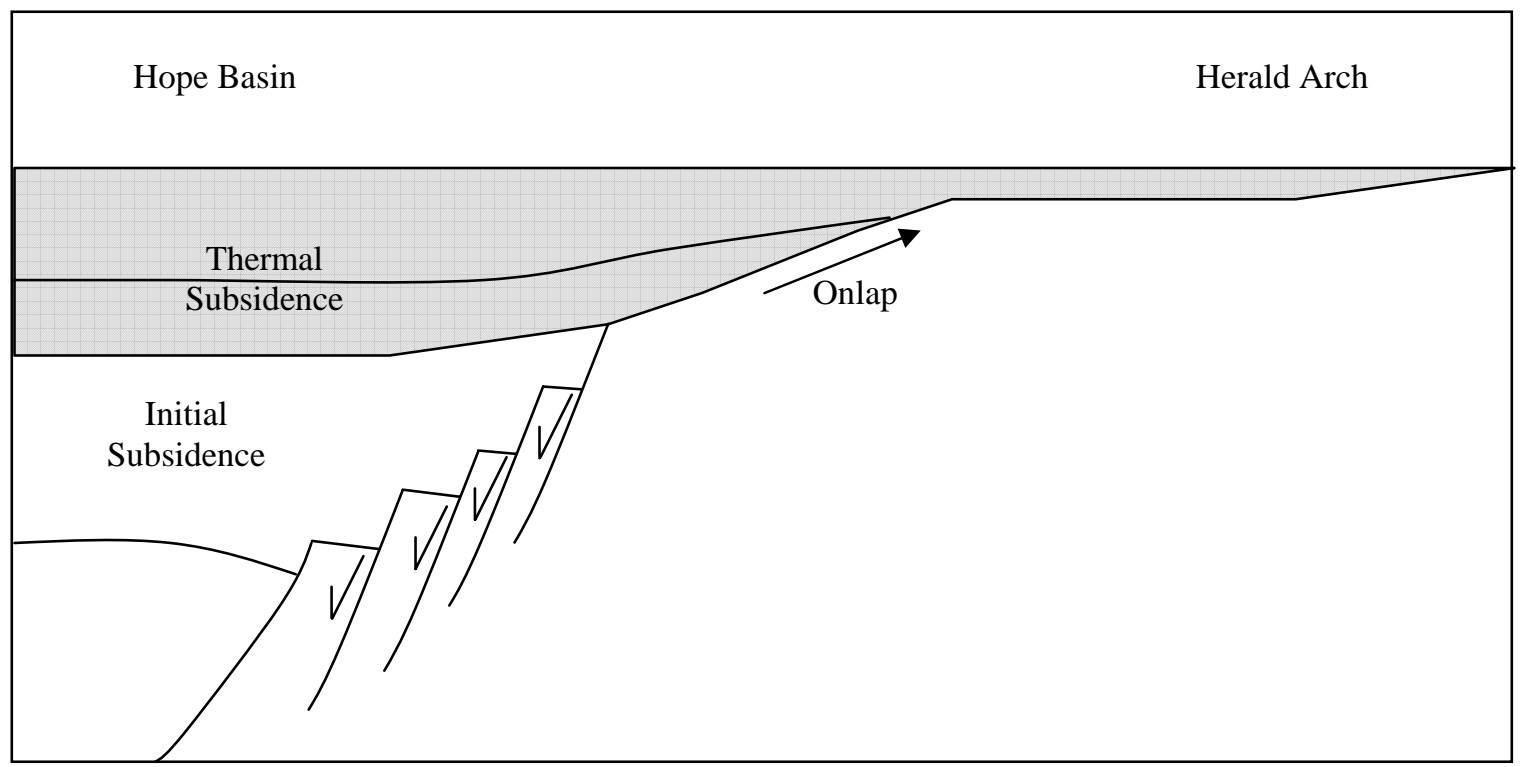

Figure 5: Generalized model of the shape for the McKenzie steer's head geometry of a sedimentary basin. The first subsidence stage is fault driven followed by a cooling and thermally driven subsidence stage. In this cartoon, the Herald Arch would begin in the area beneath the onlap section and continue to the right. The Hope Basin appears mainly as a the fault driven initial subsidence stage with some thermal subsidence and onlap features beginning to form. The mirror image of this would model the southern part of the Hanna Trough with the onlap going onto the Herald Arch. Modified from White and McKenzie (1988). 


\section{Chapter 3: Geologic History and Setting}

\section{1: Regional Setting}

“The geologic history of Alaska can be described by the progressive southward growth of continental crust by accretion and imbrication of continental margin and oceanic sediment, allochthonous terranes, magmatic arc systems and ophiolitic rock against a more rigid lithospheric block” to the north (Klemperer et al, 2002). Seismic studies have shown that Alaska and the Chukchi and Bering Seas can be divided into three distinct segments with unique structure and crustal histories. Going from south to north, these regions are the arc and displaced terranes, mid-Cretaceous magmatic belt and Arctic Alaska-Chukotka Plate (Klemperer et al, 2002). The mid-Cretaceous magmatic belt is a shallow feature not relevant to this study and will not be discussed further. Figure 6 shows the approximate boundaries of the arc and displaced terrains to the south and the Arctic Alaska-Chukotka plate to the north.

The southern arc and displaced terranes were assembled along transpressional faults or formed in place during the Cretaceous-Paleogene. The region includes the area south of the Brooks range, excluding the Seward Peninsula, to just south of St. Lawrence Island and then continuing to Russia (figure 6).

The Arctic Alaska-Chukotka Plate, contains the Chukchi Sea, the northern part of Russia, Beaufort Shelf, North Slope, most of the Brooks Range and Hope Basin, Herald Arch, Lisburne Hills thrust belt, Colville Basin, Hanna Trough and Seward Peninsula (figure 6). Late Devonian to Permian rifting created the fault-bound portion of the Hanna Trough which was later capped by Late Jurassic deposition (figure 2) due to regional 
subsidence (Sherwood et al., 2002). These are overlain by the Cretaceous-age Brookian Sequence of the Colville Basin foreland. The east-west trend of the Brooks Range is the result of "an arc-continent collision in the late Jurassic-Early Cretaceous" (Moore et al., 2002).

Running nearly perpendicular to the Brooks Range on the west coast of the Lisburne Peninsula is the Lisburne Thrust located within the Lisburne Hills (figure 3). Fissiontrack thermochronology indicates that the Brooks Range orogen and Lisburne Thrusting occurred simultaneously in the Cretaceous. Along with the age data, structural and stratigraphic evidence from the Lisburne Hill leads to the conclusion that the Lisburne Thrust and Brooks Range orogen are related (Amato et al., 2004).

The Lisburne Thrust continues offshore to the northwest as the Herald Thrust (figure 3). This thrust serves as the northern boundary of the Herald Arch, a band of basement rock extending from the Lisburne Peninsula to beyond Wrangel Island. The southern boundary of the Herald Arch are the Tertiary on-lapping sediments of the Hope Basin. This basin is an extensional basin that some studies (Moore et al., 2002) believed formed as a result of right-lateral movement along the Kobuk fault during the Paleocene. However, Elswick (2003) found no evidence for strike-slip movement and concluded the basin formed through extension. Thermal subsidence in the Early Miocene and reactivation of Paleocene normal faults in the mid to late Miocene continued the subsidence of the basin (Moore et al., 2002) contributing to the crustal thinning. 


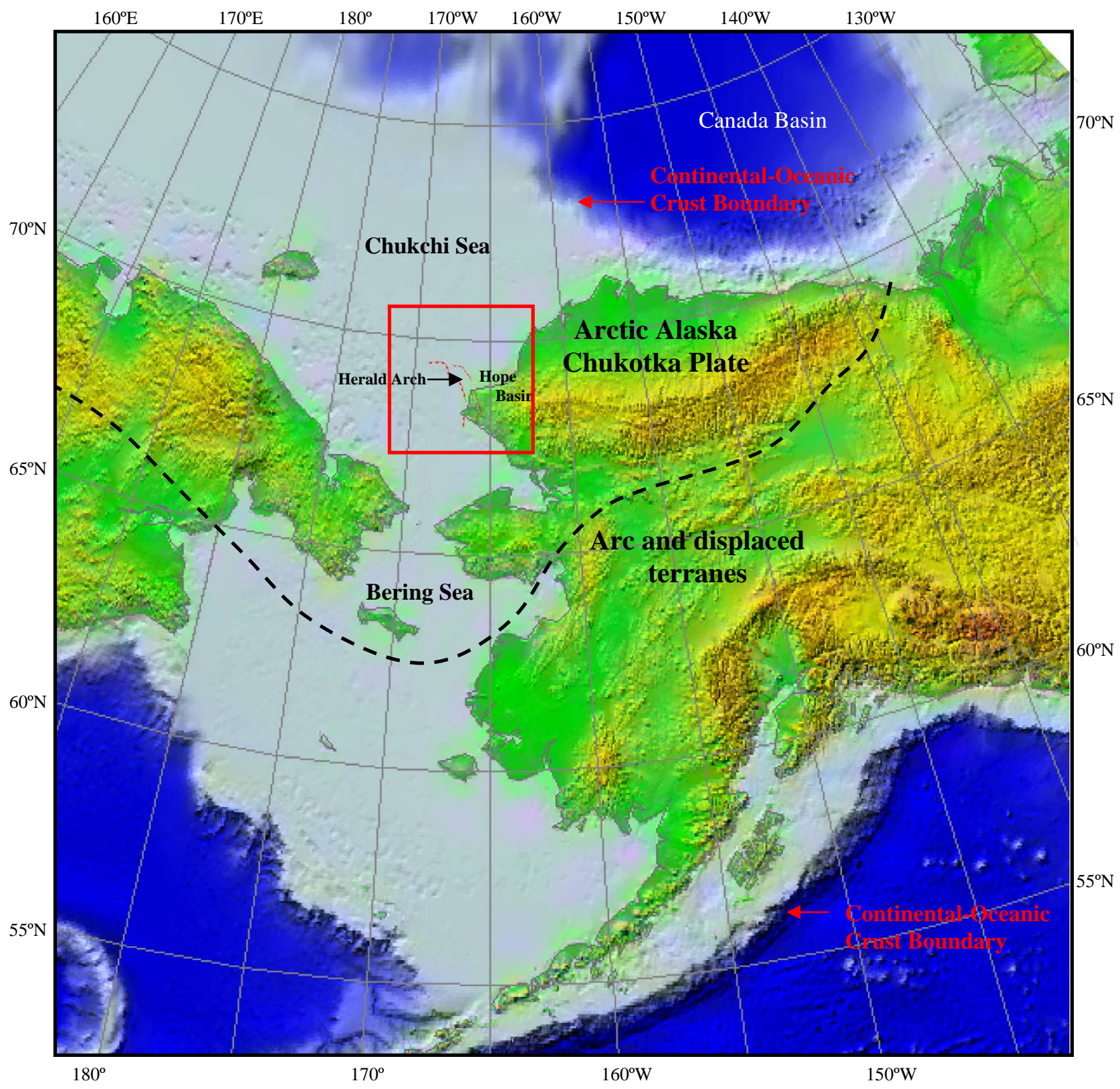

Figure 6: The two main structural regions in Alaska and the Bearing and Chukchi seas are shown as the northern Arctic Alaska Chukotka Plate and the southern Arc and displaced terranes with the dashed line dividing the two. Approximate boundaries of the regions are from Klemperer et al., 2002. Bathymetry and topography data are from Smith and Sandwell (1997). 


\section{2: Stratigraphy}

Most of the sedimentary strata north and east-northeast of the Herald Arch can be divided into four sequences, Franklinian, Ellesmerian, Rift, and Brookian (Sherwood et al., 2002). These four major sequences of the Chukchi Shelf are shown in the stratigraphic column in figure 7. Each of these sequences has a contrasting lithology and tectonic characteristics making them relatively easy to distinguish (figures 8, and 9A and 9B) (Grantz and May, 1987). The Rift sequence is not present in the study area with significant thickness and thus was not interpreted here.

The Hope Basin is located to the south of the Herald Arch (figure 1) and contains younger, Eocene-Pliocene, sediments over deformed Brookian to pre-Mississippian rock. The younger units are often divided into 3 units defined by their seismic characteristics and age (Decker et al., 1988). Only the much older basement rock was interpreted for this study but interpretations from Elswick (2003) were used. I believe the Herald Arch is composed of Mississippian to lower Paleozoic rock found on the western edge of the Lisburne Peninsula (figure 10) and below the Hope Basin.

Figure 8 shows a sample from seismic line WGS 118 (figure 10) which displays seven of the nine shallow horizons that were interpreted and figure 9A shows all the picked horizons, including the Moho. Most of these horizons were picked using the seismic interpretations from Sherwood et al. (2002) as well as the sparse well data from the Tunalik and Klondike wells (figure 10). The rock below the basement (red) reflector, figure 7, is the Franklinian sequence. Between the basement (red) and LCU (blue) reflectors is the flat-lying Ellesmerian sequence. The remaining reflectors above the LCU and below the AU (pink) are the Brookian rocks. These are the units that were used 
to estimate shortening of the crust and are were divided into three arbitrary sections based on their seismic characteristics, B2 (green), B1 (yellow), and B0 (orange). The thin layer above the AU is interpreted as mostly Quaternary marine sediment.

Two arbitrary lines were picked to interpret the Herald Arch. These horizons have no wells that correlate them. Using the on land geology (figure 10), I projected the horizons to the Herald Arch. The upper horizon I have called the Mississippian Unconformity (MU) but probably its stratigraphic identification is only approximate. The lower horizon I have labeled as the Devonian Marker (DM). This horizon, like the MU, was used to show the trend of the Herald Arch and for the reconstructions to estimate the amount of shortening. 


\section{U.S. CHUKCHI SHELF STRATIGRAPHIC COLUMN}

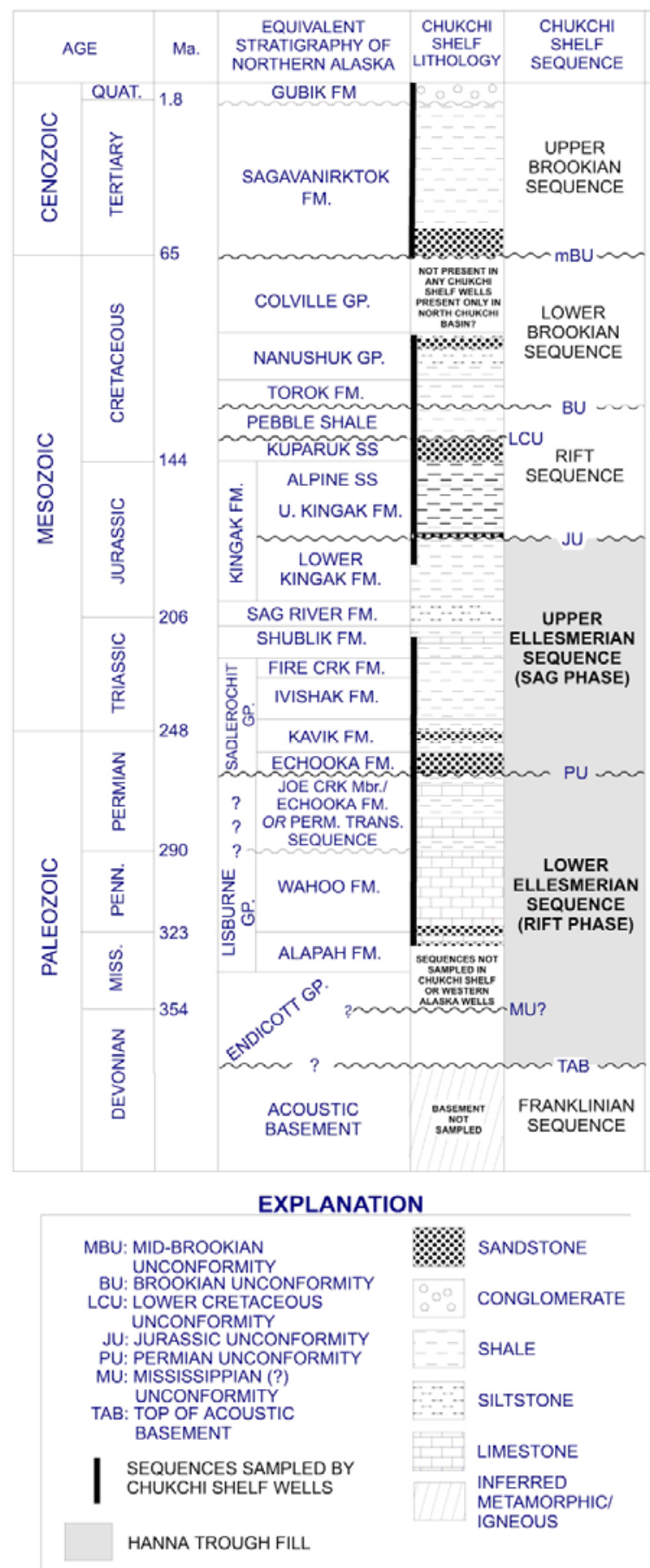

Figure 7: Stratigraphic column of northwest Alaska from Sherwood et al.,2002. The horizons that were interpreted for this study and that are shown here are; the top of acoustic basement (TAB), approximate Mississippian Unconformity (MU), Permian Unconformity (PU) separating the upper and lower Ellesmerian Sequences and the Lower Cretaceous Unconformity (LCU) inferred to be the top of the Ellesmerian Sequence for this study. The thickness between the Jurassic Unconformity (JU) and LCU was small $(0.25 \mathrm{sec})$ for this study area so only the LCU was interpreted. 


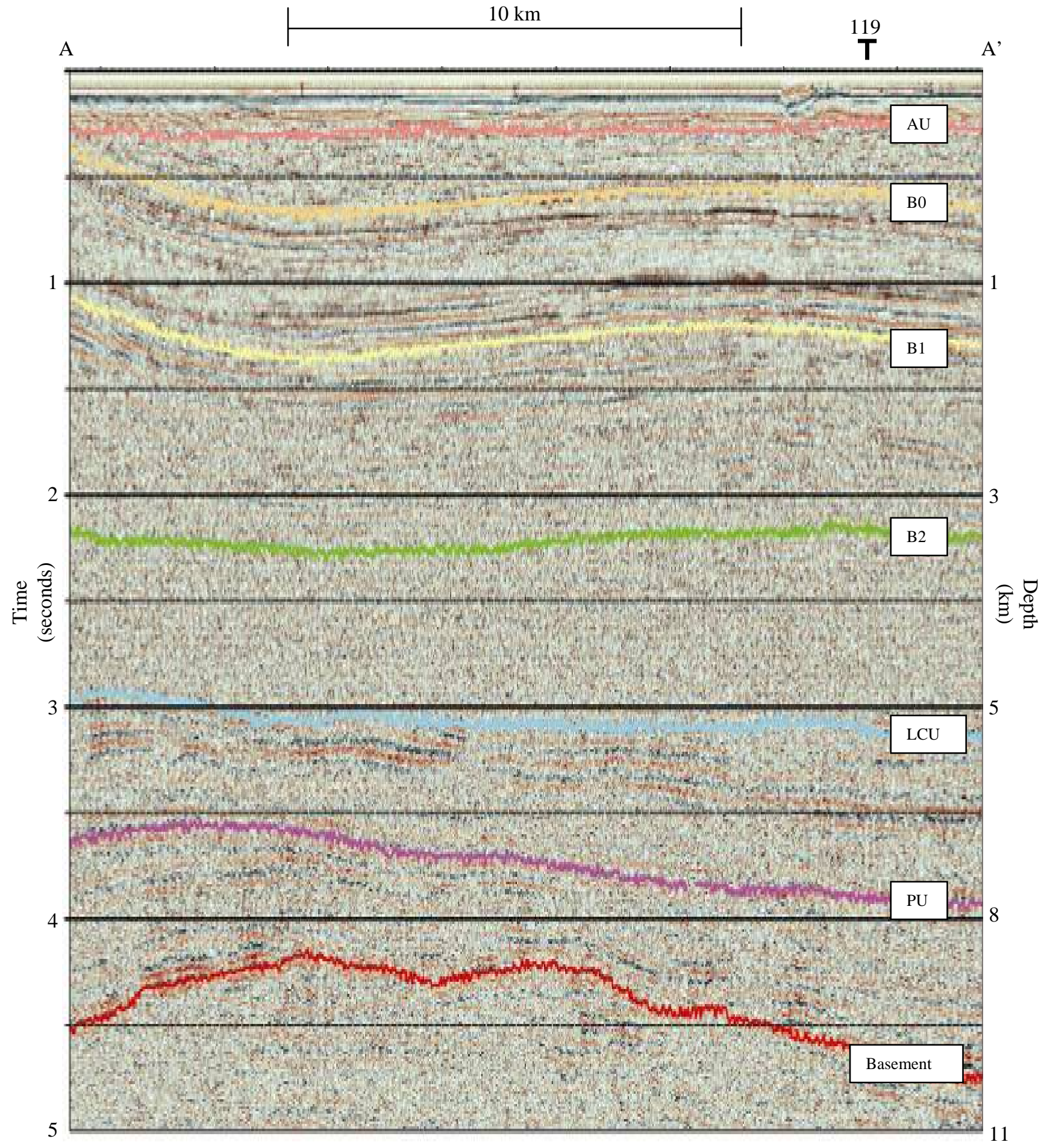

Figure 8: This is a section of line 118 located to the north-east of the Herald Arch. See figure 10 for the location of this crossection. The vertical dimension has been exaggerated to about twice that of the horizontal. The red marker is the basement horizon, purple is Permian Unconformity (PU), blue is the Lower Cretaceous Unconformity (LCU), green is the Brookian 2 (B2), yellow is the Brookian 1 (B1), light orange is the Brookian 0 (B0) and the angular unconformity (AU) is represented by the pink horizon. 


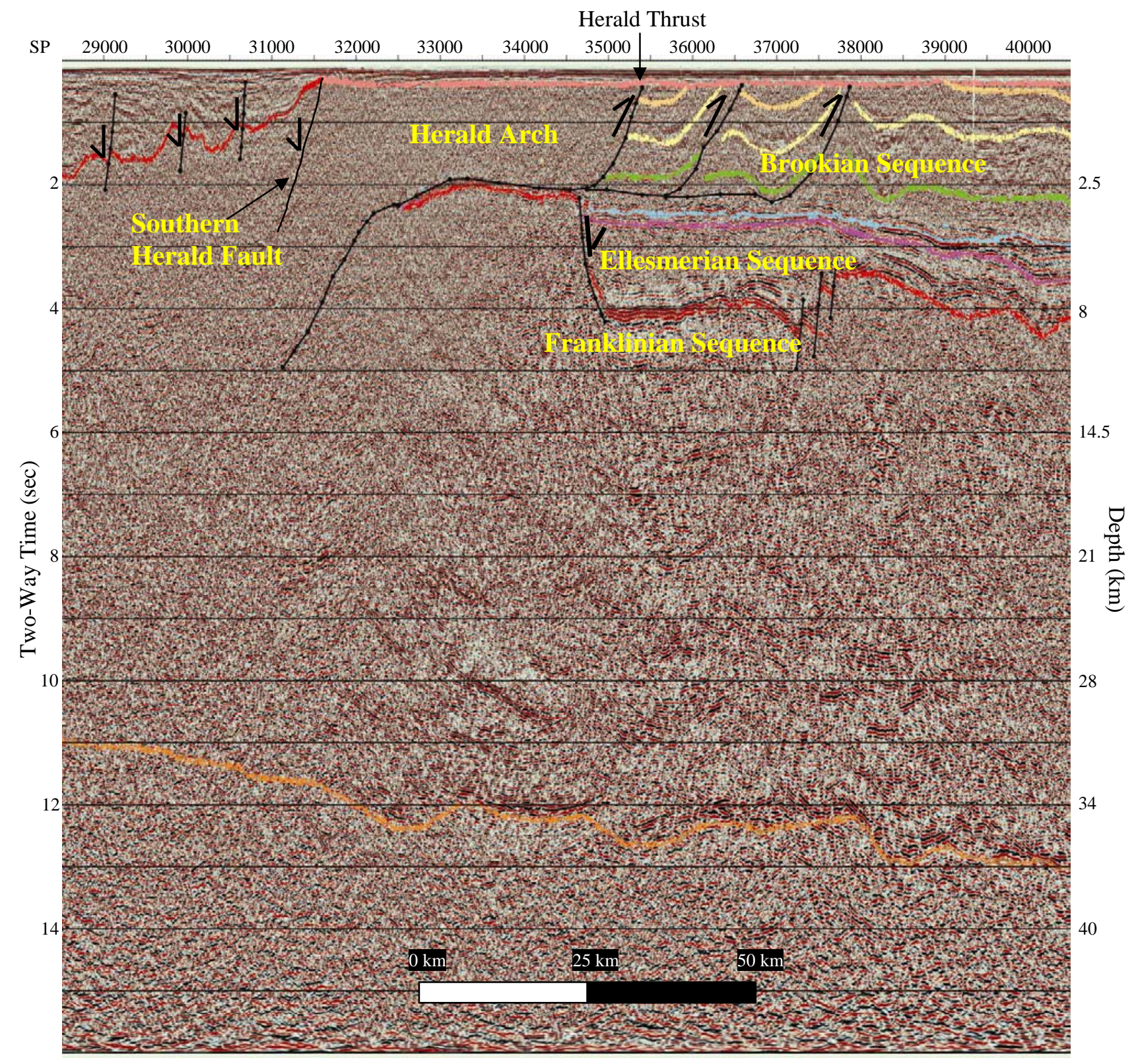

Figure 9A: A section of line 5181, the USGS-Stanford deep crustal lines. The location for this line is shown on figure 10 and this seismic image has approximately 2.9 times vertical exaggeration. This is showing the Moho (orange), basement (red), JU (purple), LCU (blue), B2 (green), B1 (yellow), B0 (light orange) and AU (pink) horizons. The three main sequences, Franklinian, Ellesmerian and Brooking are shown along with the Herald Arch. The crustal thinning can be seen as the rise of the reflection Moho from north (right) to south (left). 


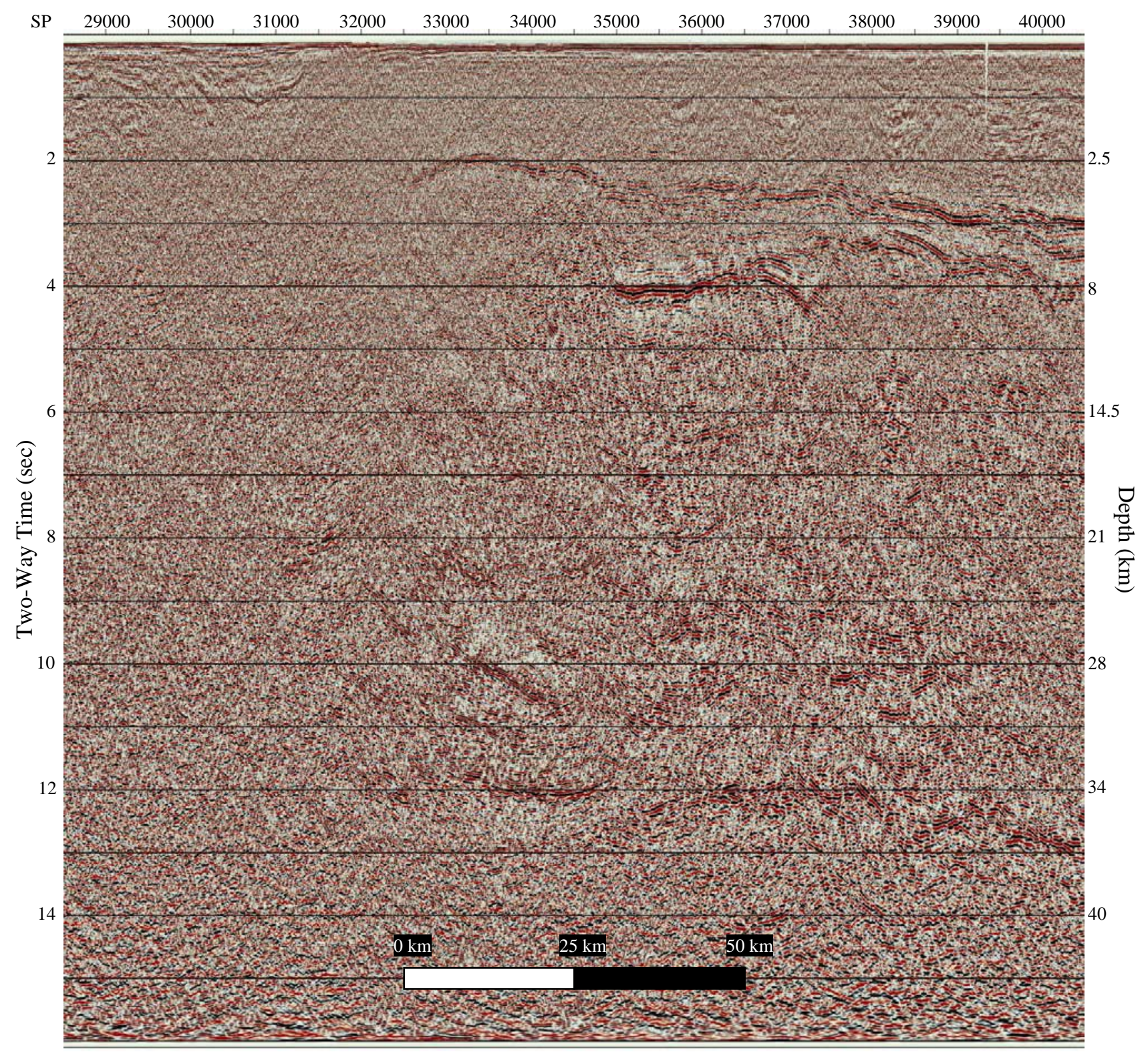

Figure 9B: This is the same section of line 5181 from figure 8A with the same 2.9 vertical exaggeration. Here the USGS-Stanford deep crustal line has been processed but has not been interpreted. 


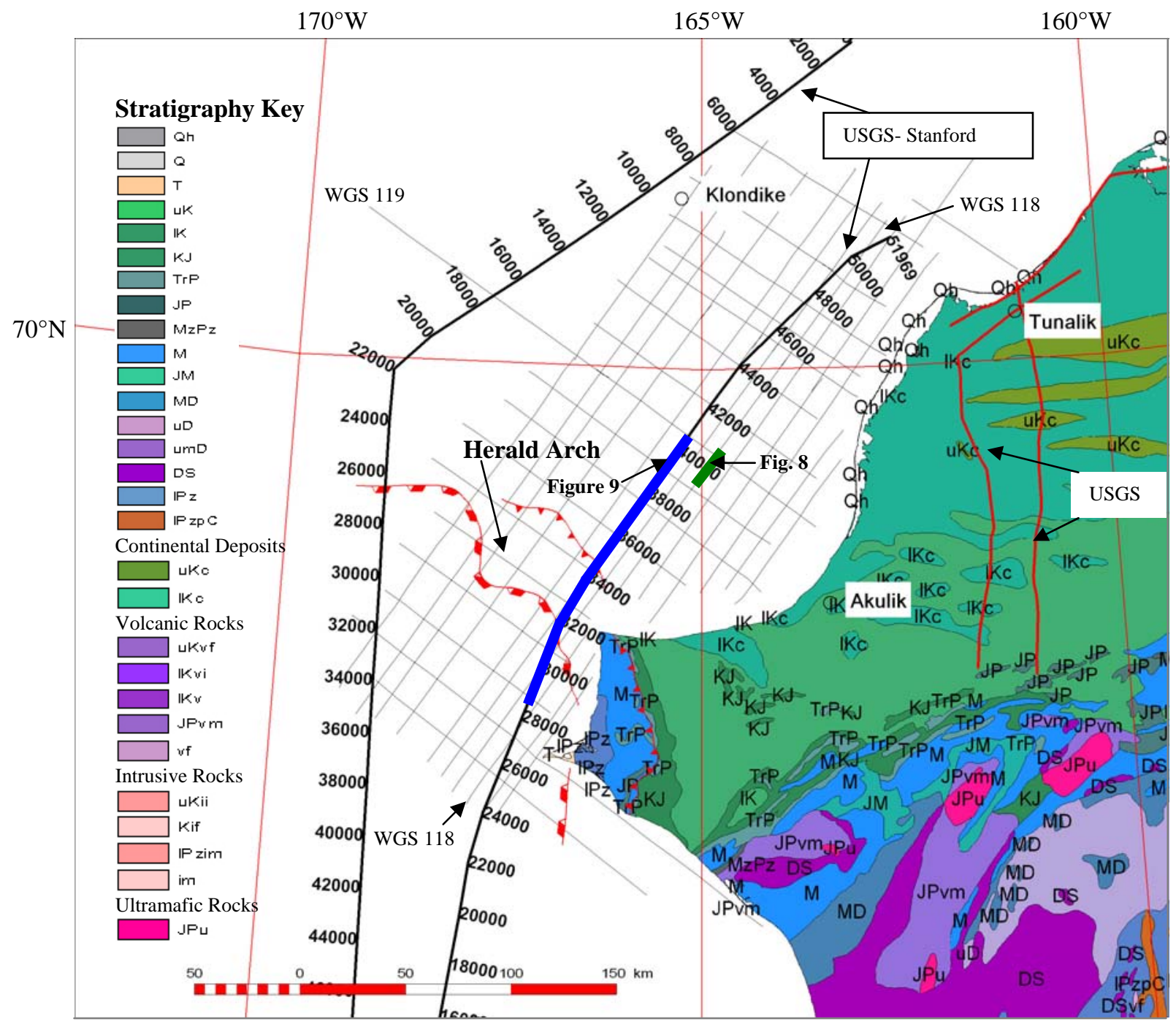

Figure 10: Location map showing seismic data, and onland geology used in this study. Heavy black lines are the USGS-Stanford lines with a 2000 shot point interval labeled. The light black lines are the Western Geco (WGS) lines and the red the USGS lines. Additional descriptions for the on land geological units can be found in appendix 1. The green line is the location of the cross section for figure 8 and the blue line is the cross section for figures 9A and 9B. Geologic data is from Beikman (1980). 


\subsection{1: Pre-Mississippian/Franklinian/Acoustic Basement}

Beneath the Chukchi Sea and Hanna Trough sedimentary rocks, basement rock extends throughout the region and is grouped together as the Franklinian sequence (figure 9A and plate 2). This unit is both economic and acoustic basement and probably represents “collapsed basins and accreted terranes” joined together during the Devonian period (Sherwood et al., 2002). These units are believed to have been deformed and buried by the Ellesmerian orogeny of northern Alaska in the early to middle Devonian (Moore et al., 1994).

The Franklinian sequence has been shown to be composed of multiple stratigraphic units with varying source areas and origins. This sequence is often referred to as the pre-Mississippian sequence, especially when referring to the on-land North Slope subterrane where a sub-Mississippian unconformity truncates most of the older rocks (Moore et al., 1994).

No wells have penetrated the off-shore Chukchi Shelf basement rock but onshore wells and wells along the Barrow Arch (Moore et al., 1994) have encountered tectonized siliciclastics which include: argillite, slate, phyllite and other minor quartzites along with fossils of Ordovician and Silurian age. However, phyllites from wells along the north coast of Alaska have revealed ages ranging from 547-592 Ma from K-Ar radiometric dating (Sherwood et al., 2002). On-land, along the west coast of the Lisburne Peninsula, pre-Mississippian rocks of Ordovician to Silurian in age consist of black argillite, siliceous shale and sand-rich turbidites (Moore et al., 2002).

Off-shore basement rock interpretations are limited to seismic, gravity and magnetic data. These geophysical investigations reveal moderately deformed rocks that 
are possibly carbonates and clastics which are over 9000 meters thick (Sherwood et al., 2002). There are only a few scattered reflectors between the basement and Moho horizons on the available seismic data. These reflectors are usually steeply dipping and non-continuous (figure 9A).

\subsection{2: Ellesmerian Sequence}

Most of the rock between the basement reflector (red) and the Lower Cretaceous unconformity, LCU reflector (blue), are grouped together as the Ellesmerian Sequence. The Jurassic unconformity, JU, is the true top of the sequence but was difficult to discern between the LCU and PU reflectors (Sherwood et al., 2002). The Klondike well (figure 10) found the Jurassic unconformity at a depth of 9400 feet (2865 m) and the Lower Cretaceous unconformity at 8800 feet $(2682 \mathrm{~m})$. The 600 feet $(183 \mathrm{~m})$ between the two markers appears within about $1 / 4$ of a second on the seismic data at that depth. The Tunalik well (figure 10) shows the two unconformities much farther apart with the JU at 13700 feet (4176 m) and the LCU at 10900 feet (3322 m). However, this 2800 feet (853 m) diminishes to less then 600 feet $(183 \mathrm{~m})$ when reaching the study area and after crossing the axis of the Hanna Trough (figure 2). For this study the LCU horizon was picked as the top of the Ellesmerian sequence because it was easier to pick out on both the Klondike and Tunalik wells and it was possible to correlate it across the faults of the Hanna Trough.

The Ellesmerian sequence was deposited from the Late Devonian to the Late Jurassic on a south-facing continental shelf. An elevated terrain to the north, due to the Ellesmerian orogeny, acted as the source area to provide sediment for the Hanna Trough basin which reaches thicknesses of up to 6700 meters (Sherwood et al., 2002). 
The Ellesmerian is often divided into a lower, rift driven subunit, and an upper, thermally driven subsidence basin subunit. These two divisions of the Ellesmerian can also be subdivided into additional groups but will not be discussed here because they are too fine to be discerned on the available seismic data. The rift-driven sequence fills the base of the Hanna trough, up to the tops of most of the faults marking the half-grabbens, and is typically wedge-shaped (Sherwood, et al., 2002) with the thicker sides being on the eastern-flank with the steeper faults (figure 2 and plate 2).

Most of the strata at the base of the Lower Ellesmerian sequence were probably deposited in shallow marine settings as is evident of the wave ripples, bioturbadation and carbonates found in the sediments on the Lisburne Peninsula. Many of the strong reflectors within the Lower Ellesmerian Sequence (figures 2) are believed to be the carbonates of Lisburne Group, a major unit of the Lower Ellesmerian Sequence (figure 7). However, there is also evidence for nonmarine conditions such as channelized upward thinning and fining sequences of sandstone about 2 meters thick which is capped by coal. The combined evidence indicates a probable "deltaic region with abundant distributary bays, estuaries, lagoons and tidal flats” (Moore, et al, 2002). The top of the Lower Ellesmerian sequence can be described as platform of carbonate succession wide spread in northern Alaska (Moore, et al, 2002).

The Upper Ellesmerian sequence is believed to have formed when faulting was not as active and accommodation space was created from thermal subsidence (Sherwood et al., 2002). The main marker for this unit is the strong and continuous reflector of the LCU which made the correlation for the top of the Ellesmerian relatively easy to follow. Going from southwest to northeast, the reflector gently dips towards the Hanna Trough 
until rising again after crossing over the Hanna Trough. The source area for the Upper Ellesmerian rocks is believed to be the same northern uplifted area that was responsible for the Lower Ellesmerian rocks (Sherwood et al., 2002). In the Lisburne Hills, multiple formations can be distinguished but are impossible to discern on seismic data. The sequence is composed of shale with beds of chert and carbonate rocks (figure 7) (Moore, et al, 2002).

\subsection{3: Rift Sequence}

Another phase of rifting along the Beaufort continental margin (figure 1) began in the Jurassic resulting in the North Chukchi Basin. The resulting grabens and flexural downwarps containing thick sequences of clastic rock are located northeast of the study area. Within this study area, the Rift Sequence is preserved as a thin (1/4 second) section of rock just below the LCU. This sequence is composed mainly of shales and sandstones with an age range from late Jurassic to early Cretaceous.

Due to the depth of the Upper Ellesmerian and the resolution of the available seismic data, most of the thin Rift Sequence (between the Ellesmerian and Brookian Sequences) is incorporated into the top of the Ellesmerian strata. The rift sequence on the Tunalik well is thick, going from 10600 feet (3230 m) to 13700 feet (4175 m), however, this 3100 feet $(945 \mathrm{~m})$ thins to 1100 feet $(335 \mathrm{~m})$ on the Klondike well where it is found from 8300 feet $(2530 \mathrm{~m})$ to 9400 feet (2865 m). Most of the thinning takes place crossing through the Hanna Trough. 


\subsection{4: Brookian Sequence}

The Brookian Sequence makes up the North Slope and Colville basin foreland basin-fill. The basin encompasses everything from the Lower Cretaceous Unconformity (LCU) (blue) to the angular unconformity (AU) (pink) (figures 8 and 9A). This sequence reaches a thickness of over 10600 feet (3180 m) in the Tunalik well (figure 10) but thins slightly towards the west and south with the Klondike well recording a thickness of over 8800 feet (2640 m). Between the LCU and the true base of the Brookian Sequence lies the pebble shale unit. This unit does not appear in the Tunalik well but does show up as a 500 foot (150 m) thick section in the Klondike well (Klemperer et al., 2002) and was thus incorporated along with the Brookian Sequence.

This unit is the structurally highest unit in the area northeast of the Herald Arch and consists of middle Jurassic to Tertiary, northeast prograding shallow marine and nonmarine deposits of mudstone, sandstone and conglomerates. The majority of the Brookian Sequence has a source area to the south, present day Brooks Range, and southwest (Bird and Molenaar, 1992). Individual groups and formations were not correlated due to the poor quality of the seismic data. Instead, three arbitrary horizons were chosen based on their well-defined seismic character and regional extent within the data set. These horizons will be discussed again later.

\section{3: Geological History Overview}

The present day basement and Franklinian rocks are believed to be a diverse assemblage of collapsed basins and accreted terrains which were all bound together during the Devonian. These could contain a north trending magmatic complex not visible 
on seismic but identified in the magnetic data (figure 35) (Sherwood et al., 2002) and contribute to the orientation of the Hanna Trough, Colville Basin and Herald Arch. Due to the depth, harsh conditions and lack of positive petroleum returns from test wells, little is known about the basement rock, however the geologic history of the Ellesmerian and younger sequences are better understood than the older metamorphosed basement and Franklinian rocks.

Above the Franklinian sequence are the Devonian to Late Jurassic strata of the Hanna Trough. On seismic, the Hanna Trough appears to be bounded by normal faults between 2 and 5 seconds deep (figure 2). Some of the deeper faults cut into the basement rock, but most of the offset is visible within the Ellesmerian Sequence. Figure 11 shows a graphical history of the Hanna Trough and the general tectonic history of the northern Chukchi Shelf. The large asymmetric, rift grabbens of the Hanna Trough were filled from an elevated source to the north created by the Ellesmerian Orogeny. The trough was filled during two stages, first a rift driven event with numerous normal faults (figure 11A), then a thermal subsidence event with minimal faulting (figure 11B).

The Devonian rift phase created an asymmetric basin with a steep normal fault on the east and a gentle normal fault towards the west. The western boundary of the trough is not clear with numerous normal faults being found west of the main axis of the trough north of the study area. However, on figure 3 the western edge of the Hanna Trough is identified as the last grabben just before reaching the Herald Thrust. The eastern boundary is better defined by the edge of the Arctic Platform but is not shown in this study. 
The thermal subsidence phase took place from the Permian to Late Jurassic and is marked by the Upper Ellesmerian Sequence. The older rift faults did not contribute much to the continued deepening of the basin. This phase is capped by the Jurassic Unconformity (JU) marking the base of the Rift Sequence. This second rift phase took place along the Beaufort continental margin and continued into the Chukchi Shelf but is not well represented in my study area.

During the Early Cretaceous through Campanian, the Canada Basin began to open causing the Arctic Alaska Chukotka Plate to rotate counter clockwise. This led to "the emplacement of ophiolitic allochthons on the south facing continental margin” (figure 11C) (Moore et al., 2002) and the creation of the Brooks Range with the Colville Basin to the north of the range. This mountain chain provided the sediment source for the majority of the foreland Colville Basin to the north (figure 11 D) (Sherwood et al., 2002).

Presently, the Brooks Range extends for 800 km east-west across northern Alaska until reaching the western edge on the Lisburne Peninsula where it changes to a northsouth trend along the Chukchi Syntaxis (Moore, et al, 2002). The northward trend, Lisburne Hills on land and Herald Arch offshore, is believed to be part of the Brooks Range and not due to a separate east-west shortening event. The evidence for this is the similar deformation age and structural and stratigraphic similarities. The change in strike takes place under the Chukchi Sea at the Chukchi Syntaxis (Moore et al., 2002) and will be discussed later in greater detail.

After the thrusting of the Brooks Range in the Early to Late Cretaceous, additional shortening is believed to have taken place about $60 \mathrm{Ma}$. This shortening is responsible for the numerous thrust faults and folds found in the Brookian Sequence of 
the Colville Basin (Moore et al., 2002). Finally, extensional collapse of the elevated terrain along the Herald arch formed Hope Basin by multi-stages involving the Kobuk strike-slip fault in the early Paleocene, thermal subsidence in the Early Miocene and the reactivation and extension along faults during the Late Miocene (Elswick, 2003).

\subsection{1: Chukchi Syntaxis}

There are a variety of theories for the origin of the north to northwest trending Lisburne Hills-Herald and Wrangel Arch structures. This fold and thrust belt could have been created separately or along with the Brooks Range orogenic event. Another possibility is that the Lisburne Hills-Herald Arch orientation is the result of paleogeographic irregularities (Moore et al., 2002). The most recent literature states the two features formed together and their present day relative orientations are the result of a series of geologic events that will be described below (Amato et al., 2004).

Studies done by Grantz $(1970,1975,1981)$ showed an apparent truncation or deformation of regional folds in Middle and Upper Cretaceous rocks by the Brooks Range orogen on the Lisburne Hills-Herald Arch. This led to the belief that the Lisburne Hills-Herald Arch was younger then the Brooks Range and therefore a separate event. Other studies by Tailleur and Brosge (1970) and Patton and Tailleur (1977) suggest the two thrust belts are part of the same event but the Herald Arch was rotated to its present location by oroclinal bending at the Chukchi syntaxis (Moore et al., 2002).

As Moore (2002) discussed, the evidence for a separate deformation event to produce the folding of the Herald and Wrangel Arches is not convincing. Instead, there is evidence in favor of a simultaneous thrusting event. The geometry and magnitude of 


\section{GEOLOGICAL EVOLUTION OF CHUKCHI SHELF}
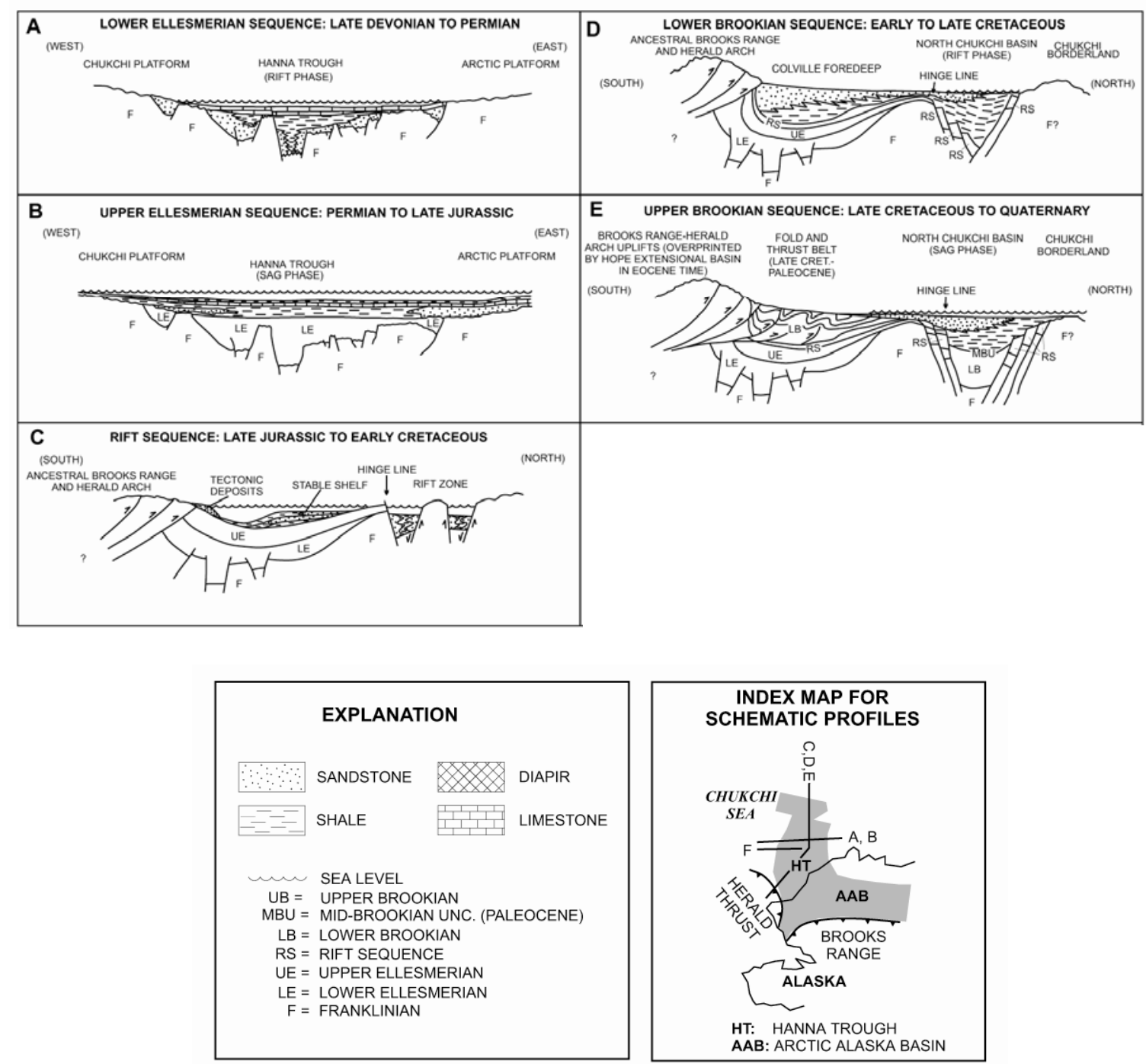

Figure 11: The geological history of the Hanna Trough and most of the Chukchi shelf. Figure A shows the rifting and creation of the Hanna Trough and the deposition of the lower Ellesmerian Sequence. Figure B shows the continued saging and thermal cooling stage of the formation of the basin along with the deposition of the upper Ellesmerian Sequence. Figure $\mathrm{C}$ begins the thrusting of the Brooks Range and Herald Arch along with the Rift sequence. Figure D begins the deposition of the Colville Basin and the continued thrusting of the Brooks Range and Herald Thrust. Figure $\mathrm{E}$ is the deformation of the Colville Basin creating the B2-B0 thrust faults. Modified from Sherwood et al., (2002). 
the shortening in the Lisburne Hills is similar to that found in the Brooks Range. The Lisburne Hills have experienced about 65\% shortening, which is comparable to the Brooks Range estimated shortening. The best evidence against separate events, however, is the timing of the two orogenic events from apatite fission track data. This gives a deformation for both of the belts to occur 132-115 Ma (Amato et al., 2004). If the Herald Arch and Brooks Range were formed together with a later rotation of the arch to its present location, the deformation to move the arch to its present location would result in deformation across the Bering Strait region. This would require up to $800 \mathrm{~km}$ of eastwest shortening. There is no evidence for this large quantity of compression. It is more likely that the Herald and Wrangel arches were created along with the Brooks Range Orogen (Moore, et al, 2002) and is more likely a salient, “an orogenic belt or tectonostratigraphic unit that has a curved map pattern with the convex side toward the plate boundary” caused the change in strike (Amato, et al., 2004).

The salient may be the result of a variety of factors. The first is the "primary curvature of the margin of the Arctic Alaska-Chukotak terrain” (Amato, et al., 2004). There was a bend in the plate that the salient began to form on. The second is the northsouth shortening during the Early Cretaceous of the Brooks Range. This movement enhanced the preexisting curvature to the west (Amato, et al., 2004). The third is "northsouth extension in the Bering Strait region during the mid-cretaceous and during early Tertiary in the Norton and Hope Basins that resulted in southward deflection of preexisting trends” (Amato, et al., 2004). Finally, strike-slip faulting in the Tertiary along the Kugruk fault to the south-east on the Seward Peninsula "displaced Precambrian basement rocks and Paleozoic sedimentary rocks to the south” (Amato, et al., 2004). 


\subsection{2: Herald Arch}

The Herald Arch lies above the folded lower Brookian rocks of the Colville foreland basin to the northeast and under the younger Hope Basin sedimentary rocks to the southwest (Grantz and May, 1987) and can be seen today as a continuation of the Lisburne Hills fold and thrust belt that trends offshore to the northwest (Moore, et al, 2002) (Figure 3). On seismic, it appears as non-reflective acoustic basement starting less then 0.5 seconds deep bound by well defined reflective sedimentary strata to the north and south (figure 2).

The Herald Arch is bound on the northeast by the Colville Basin and the Herald fault zone which consists of a series of faults ranging in dip from near vertical to $15^{\circ}$ (Moore, et al, 2002). The thrusts have a general dip to the southwest with a northeastward vergence. The arch is bound to the south by the younger Hope Basin where basin sediments onlap the hinterland of the thrust (Elswick, 2003). Beyond the study area to the northwest, the Herald Arch is thought to join the Wrangel Arch which then continues to Wrangel Island.

The arch itself could be composed mainly of deformed Ellesmerian and Brookian sequences and the pre-Mississippian rocks that are exposed along the southern coast of the Lisburne Peninsula. Rock collected in dredges near the crest of the Herald Arch, could be as old as Paleozoic based on compositional data (Moore et al., 2002). Continuing the trend of the Mississippian and lower Paleozoic rocks on the Lisburne Peninsula, (figure 10) I believe the arch to be composed of the same Paleozoic rocks found onshore. 
Middle Cretaceous deposits of the Brookian Sequence are deformed in front of the thrust. These deposits are believed to have been overthrust by $15 \mathrm{~km}$ or more. The detachment fault can be seen on seismic and can be traced nearly $60 \mathrm{~km}$ down dip.

Sediments from the Hope Basin can be seen to onlap the Herald Arch indicating the Hope Basin is a younger feature (Moore, 2002).

\subsection{3: Hope Basin}

The formation of the Hope basin caused the structural collapse of the Herald Arch during the Paleocene with significant subsidence during the Miocene. A series of horsts and grabens are located south of the arch. Secondary normal faults are also present and develop due to block rotation but do not reach the basement (Elswick, 2003).

The sedimentary fill in the Hope Basin can reach 18,000 feet at the deepest parts and is divided into three seismic sequences referred to as units I, II and III. Unit I is the lowest group and consists of Eocene volcanics and conglomerates. This unit lies on top of acoustic basement and has numerous discontinuous reflectors. Unit II is Oligocene through early Miocene in age and contains shallow marine and non-marine sandstones, siltstones and conglomerates. On seismic it appears as more coherent reflectors unless cut by the normal faults of the Hope Basin. The shallowest unit, III, is given an age of mid to upper Miocene. These reflectors are discontinuous and weak but are difficult to discern due to sea floor multiples (Tolson, 1987). 


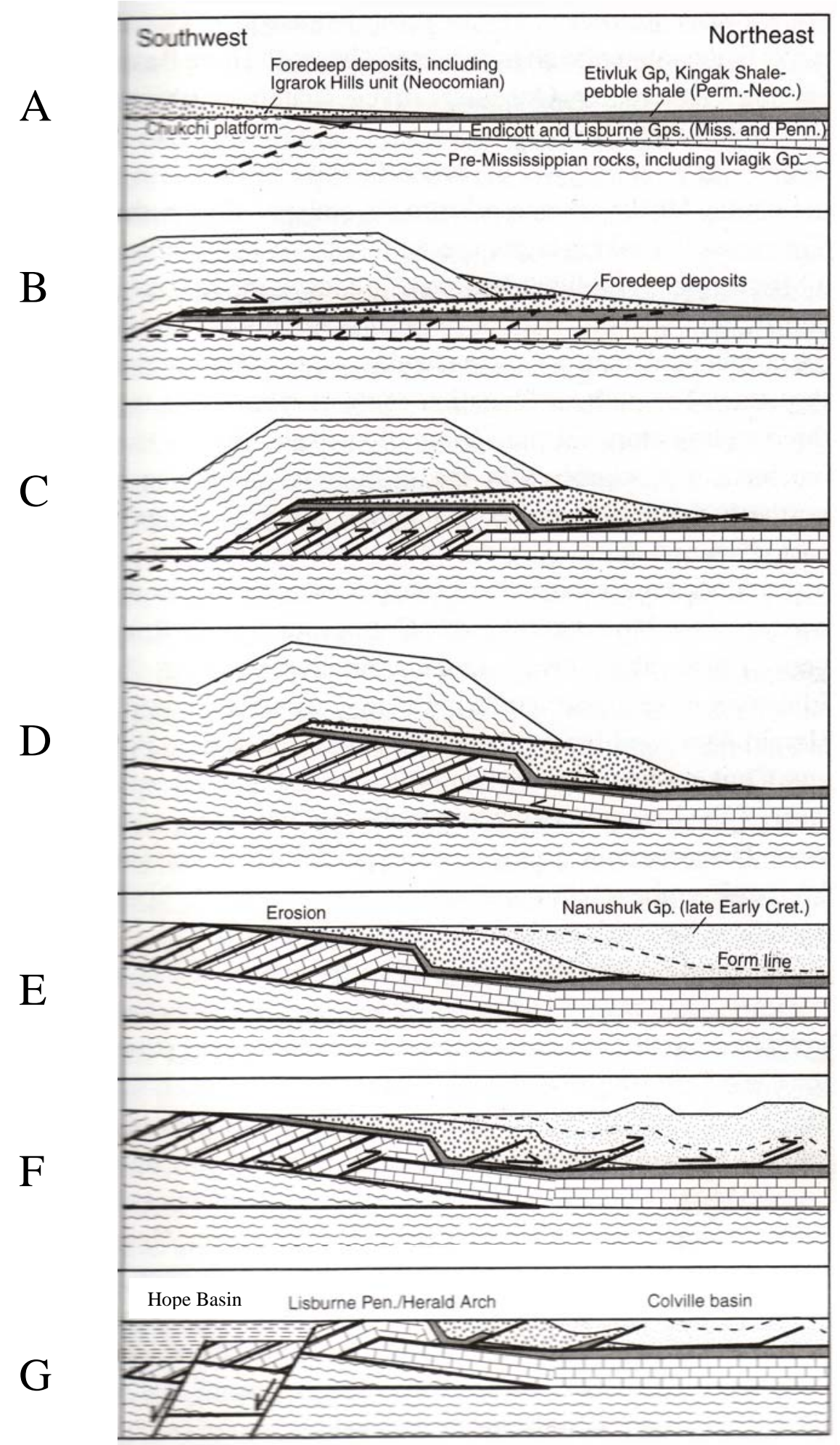

Figure 12: Regional history of the Lisburne Hills and Herald arch. Modified from Moore et al (2002). Part A shows the deposition of the Ellesmerian sequence. (B) Thrusting during or shortly after the imbrication of the Lisburne Group. (C) Thrusting of the pre-Mississippian rocks. (D) Structural thickening on thrust faults from the lower Paleozoic rocks at depth (D) Colville Basin begins to fill as erosion of the thrust continues. (E) Continued erosion and deposition of the Brookian Sequences. (F) Second period of thrusting which deforms the Brookian Sequences. (G) Extension and orogenic collapse of the Herald Arch during the formation of the Hope Basin. 


\section{Chapter 4: Geophysical Investigations}

\section{1: Well Data}

The remoteness of the region, along with the disappointing returns on a few test wells, has lead to a lack of well control for the study area, causing problems for identifying seismic reflectors. The onshore wells of Akulik and Tunalik along with the offshore well called Klondike (see figure 13 for locations) were used for this study. Of the three wells, only Tunalik reached the acoustic basement. This well lies onshore very near to three onshore USGS shallow seismic lines where the stratigraphy is mostly flat lying. Of the wells used in this study, this is also the most removed from the Herald Arch making the correlations to the main thrust area difficult. Akulik and Tunalik were used to help correlate the upper units of the Brookian Strata but the complexly folded nature of this strata and the lack of a direct tie to seismic data prevented any absolute correlation to be made. The Klondike well lies very near to seismic line WGS 102, running southwest to northeast (Figure 13), and provided the best correlation to the LCU reflector. However, this well also lies far away from the main thrust area and does not penetrate to the Permian Unconformity. 


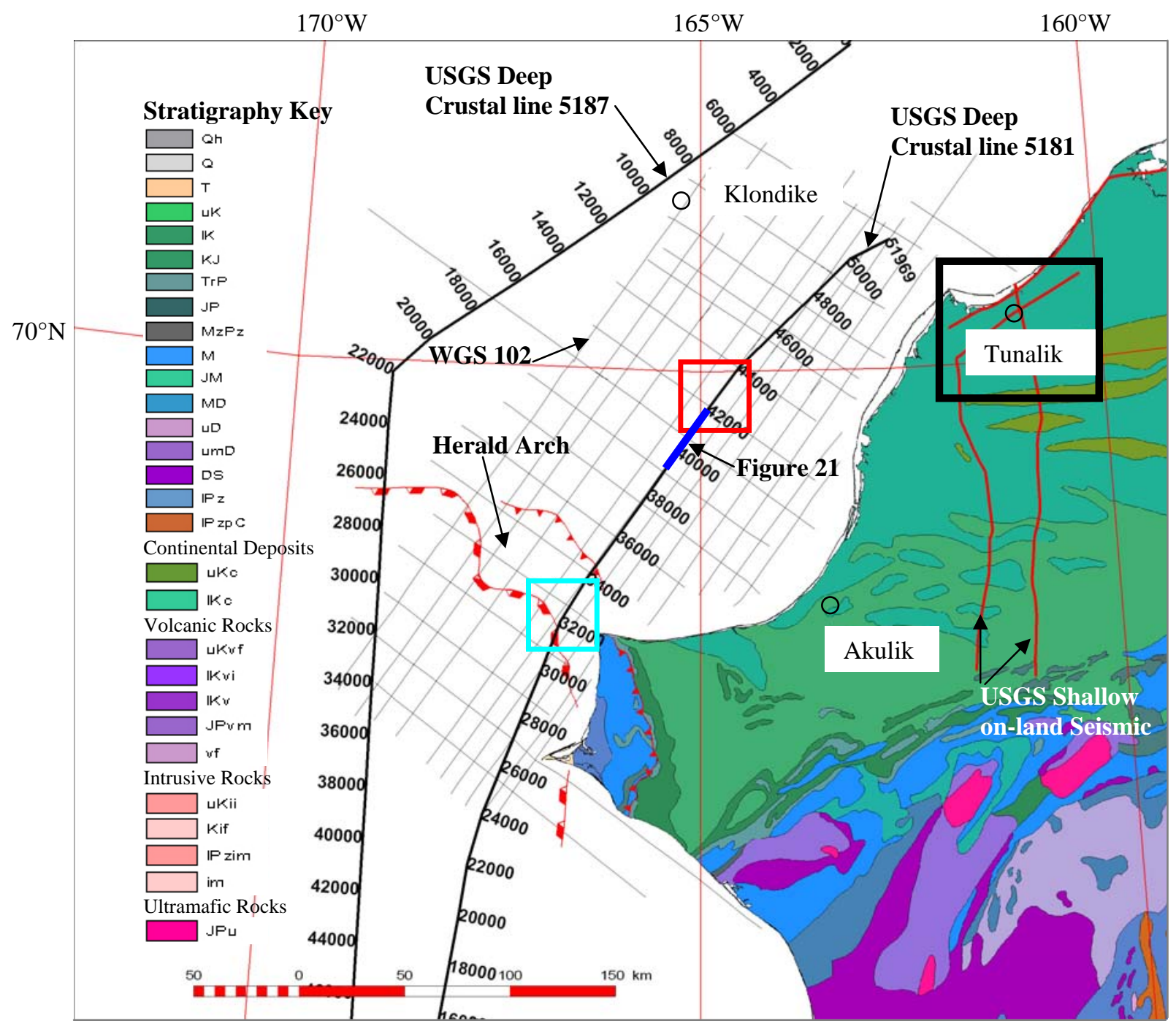

Figure 13: Locations of wells and velocity-depth refraction survey. Stanford-USGS deep crustal lines are heavy black, Western Geco shallow lines are light black, and the USGS shallow lines are red in this figure. The three wells that were used in this study are also shown. The black box indicates the onshore USGS seismic lines which were used to correlate the well data with the offshore Western Geco lines. The red box (Hanna Trough) and blue box (Herald Arch) are the locations of the refraction surveys which were used to calculate the velocity-depth curve, figure 14 . The blue line shows the cross section location for figure 21. Geological data from Beikman (1980). 


\section{2: Seismic Data}

This study used seismic data from three sources, two shallow seismic surveys and a deep reflection survey. See figure 13 for the location of all the lines. The shallow seismic data from Western Geco provided an extensive grid over the area of the Herald Arch and the thrust sheets to the northeast and total $6450 \mathrm{~km}$ in length. These lines were also used to for correlations to the well data described previously. The shallow USGS lines were of much poorer quality than the Western Geco and were not used to create any of the structure or isopach maps. The two deep seismic profiles used in the study provided the only means of studying the deep reflection Moho. Only the northern 355 $\mathrm{km}$ of line 5181 and $400 \mathrm{~km}$ of line 5187 were used for this study.

\subsection{1: WesternGeco Seismic Data}

The most extensively used seismic data come from the publicly available Western Geco shallow seismic data, figure 13. These were collected in 1980 and 1981 and consist of nearly $6500 \mathrm{~km}$ of marine seismic lines. Two-way-times of 6 to 6.5 seconds were recorded using a 2 ms sampling rate and a 50-80 foot shot point interval. These data have been processed by pre-stack deconvolution, stacked and migrated as well as high and low band pass filters (NAMSS, 2005) and were downloaded from the National Archive of Marine Seismic Surveys website.

The data set provided moderately good quality data for the areas to the north of the Herald Arch in the vicinity of the Colville Basin as well as good quality for the sediments of the Hope Basin to the south. Beneath the Hope Basin basement, the data becomes very poor with faint horizontal reflectors that are difficult to correlate to the 
Herald Ach area. The arch itself generally has poor reflectors making the correlations of reflectors difficult. One line, WGS 110, was removed from the study due to the numerous multiples and data gaps concentrated over the area of interest.

The Western Geco seismic data set provides nearly all the control points for each of the structure and isopach maps created except for the Moho maps. This data set was also used in conjunction with the on land USGS data set to tie the seismic data to the on shore Tunalik well. The northwestern most Western Geco line was used to correlate the shallow Brookian units to the off-shore Klondike well.

\subsection{2: USGS Seismic Data}

The USGS shallow seismic data were collected between 1977 and 1980 and totals several thousands of kilometers in length. "The recording system used was a Globe Universal Sciences model 4200 recording 24 channels at a 2 millisecond sample rate” (Agena, 2001). Five air-guns with a total of 1326 cubic inches were used as the seismic energy source and was fired at 50-meter intervals. A receiver array consisting of 24 groups of hydrophones spaced at 100-meter intervals gave the array total length of 2400 meters. Recording times between 6 and 7 seconds were used (Agena, 2001).

The data were processed over several stages including: demultiplexing and resampling to $4 \mathrm{~ms}$, static corrections to compensate for the time delays introduced in the recording system to conserve recording media, deconvolution to remove the effects of multiples, F-K Shot-Domain Filtering, NMO corrections, horizontal stacking with 12fold coverage, post-stack deconvolution and wavelet processing and F-K migration. More details on these processing procedures can be found in Agena (2001). 
The overall quality of this data is poor. There are numerous data gaps and diffractions within the data making interpretations difficult. These lines were occasionally used to verify the orientation of the WesternGeco seismic lines and provide additional means of tying the lines together. Some of the onshore lines (see box in figure 13) were useful in correlating the data from the Tunalik well with the offshore Western Geco seismic lines.

\subsection{3: Stanford and USGS Deep Crustal Lines}

The two Stanford-USGS Deep Crustal lines were largely used to study the reflection Moho. These lines also provided a refraction velocity survey which was used in this study to convert from time to depth. The western-most line also provided the last location of the Herald Arch before the edge of the study area was reached.

The seismic lines are part of a joint effort between Stanford University and the U.S. Geological Survey, and with participation by the Institute of the Lithosphere and the the Russian Academy of Sciences, and the Geodynamics Research Institute of Texas A\&M University. The purpose was to conduct deep seismic investigations of the continental crust beneath the Bering and Chukchi Seas. Two north-south transects were profiled. The eastern transect extended from $58^{\circ} 50^{\prime} \mathrm{N}, 168^{\circ} 32^{\prime} \mathrm{W}$, well within the continental shelf of the Bering Sea, north of the Pribilof Islands, to just south of the shelf edge north of Barrow, Alaska, at $71^{\circ} 49^{\prime} \mathrm{N}, 154^{\circ} 33^{\prime} \mathrm{W}$. The western transect extended from the central Chukchi Sea, well within the shelf at $71^{\circ} 23^{\prime} \mathrm{N}, 163^{\circ} 00^{\prime} \mathrm{W}$, into the Aleutian basin at $58^{\circ} 00^{\prime} \mathrm{N}, 178^{\circ} 30^{\prime} \mathrm{W}$, near Navarinsky Canyon (Klemperer et al., 2002). Both of these lines cut nearly perpendicular across the Herald Arch. Most of the multichannel data is of high quality, but bad weather, strong currents, and recording problems 
sometimes presented difficulties during data acquisition. The reflectors on the seismic data between the Herald Thrust and Hope Basin, including the Herald Arch, are poor just as they are in the shallow, Western Geco surveys.

The seismic data was acquired with the use of a " 4 km, 160 channel streamer and a 20 gun, 8355 cubic inch air gun source” (Klemperer et al., 2002). Depending on the weather, either a 40 -fold data set was obtained with a $50 \mathrm{~m}$ shot spacing or a 27 -fold data set with a $75 \mathrm{~m}$ shot spacing. Two-way recording times of 15-23 seconds were used (Klemperer et al., 2002). The lines have been generally processed with a band pass and FK filters, normal moveout, stacked and migrated.

Velocity information was created at $25 \mathrm{~km}$ intervals from the reflection data. It is believed, however, the calculated velocities and depths are larger then the true interval velocities and depths due to the processing techniques. If the seismic velocities are actually larger then those used for time-depth conversions, the calculated depths are shallower then the actual depths to the horizons. From these calculated velocities and time-depths curves were created for different parts of the study area (figure 14) and were used for this study to approximate the depth to the various horizons. 


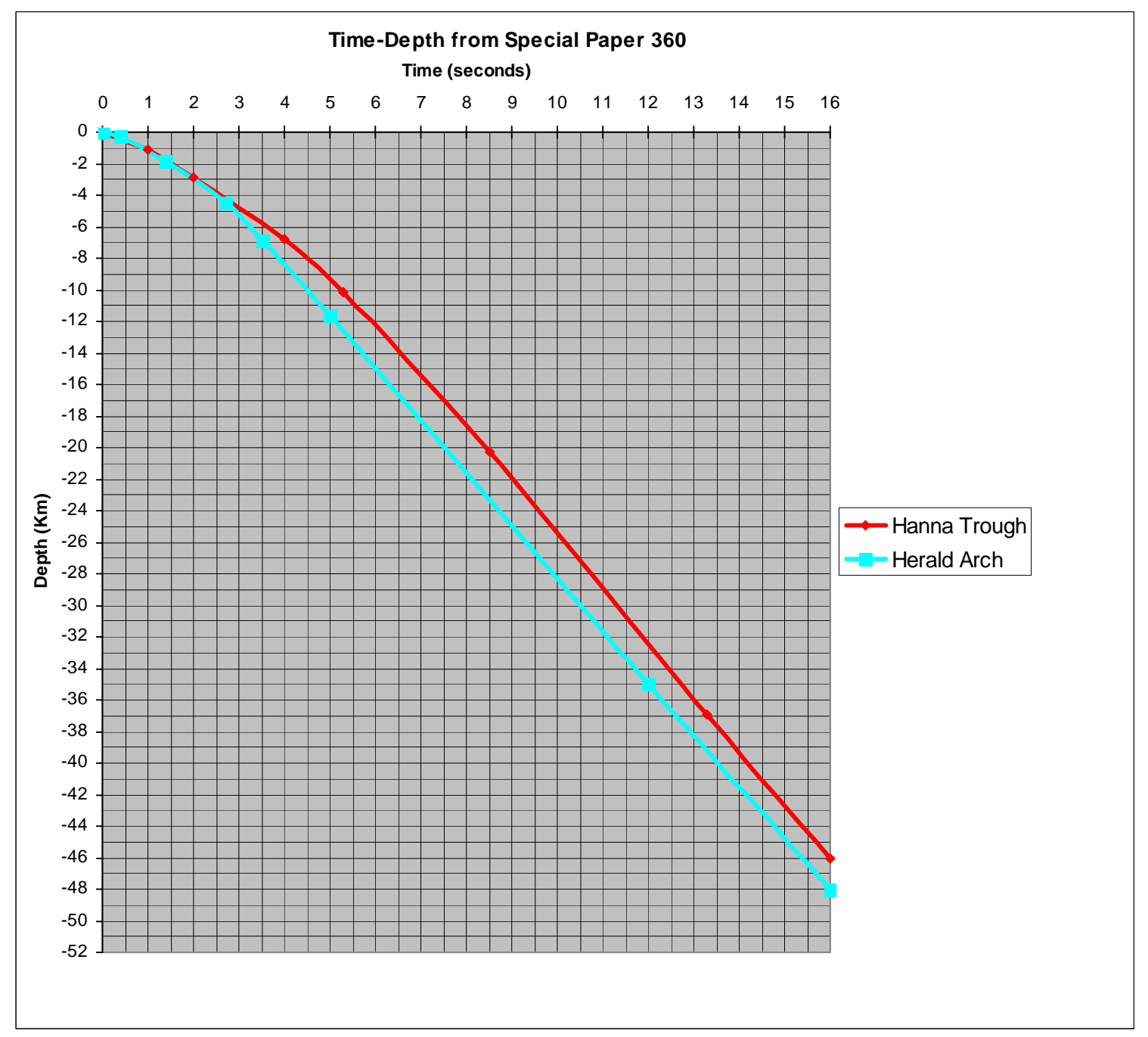

Figure 14: Time-depth conversion chart from the Deep Crustal refraction survey (Klemperer, 2002). See figure 13 for a map view of the survey locations and figure 2 for cross section view. The red curve is the velocity-depth conversion for the area over the Hanna Trough, a deep sedimentary basin with slower seismic velocities near the surface. The Herald Arch velocity-depth conversion is represented by the blue curve. The Herald Arch is believed to be composed mostly of high velocity basement rock creating a slightly steeper curve than the Hanna Trough. Additional velocity curves for the area from the Hope Basin to the Hanna Trough are plotted between the above two curves. 


\section{3: Additional Seismic Processing}

Additional post-stack filtering of the Stanford Deep Crustal lines was attempted to improve resolution of the reflection Moho for parts of the lines, especially under the Herald Arch. However, since the available data was thoroughly processed, additional processing proved of marginal value After new filters were applied, the Moho was more clearly seen in some areas but in other areas, no Moho could be discerned even after more filters were applied. The quality of the WesternGeco and USGS seismic lines did not improve with additional filtering. Most lines actually were further degraded, so no additional processing was applied prior to interpretations of the horizons.

Bandpass filters were designed using amplitude spectra completed in Kingdom Suite. Amplitude spectra are computed by taking the Fourier transform of the seismic traces to obtain the relative amplitude versus frequency content of the seismic data. Spectra were computed from a sample window with a width of 50 sequential traces and a duration between 9 and 14 seconds two-way-time for each seismic line. This window location was designed to contain the Moho reflection. Spectra were plotted at 200 shot point intervals along the USGS deep crustal line 5181 between shot points 27000 and 38000 for the area near the Herald Arch which also corresponds to the region with the poorest data quality for the reflection Moho. For example, figure 15 contains the frequency spectra for the five calculation window between shot points 27000 and 28000. The Moho is a lower frequency, longer wavelength event largely due to the depth to the zone. Filters were designed to enhance the lower frequency peak in association with the Moho reflection event. 
In addition these spectra were used to design filters to enhance deeper reflections in general. The deep reflections, like the Moho event, are characterized by low frequencies (long wavelength) due to their great depth. The higher frequency components of the seismic signal are preferentially attenuated as travel times and propagation distance increases. Most of the spectra peak frequencies with amplitudes between 5 and $11 \mathrm{~Hz}$ associate with the Moho reflection event. The two examples that follow show one where filtering was successful and the other were additional filtering did not enhance the reflectors (figures 17 through 20). 


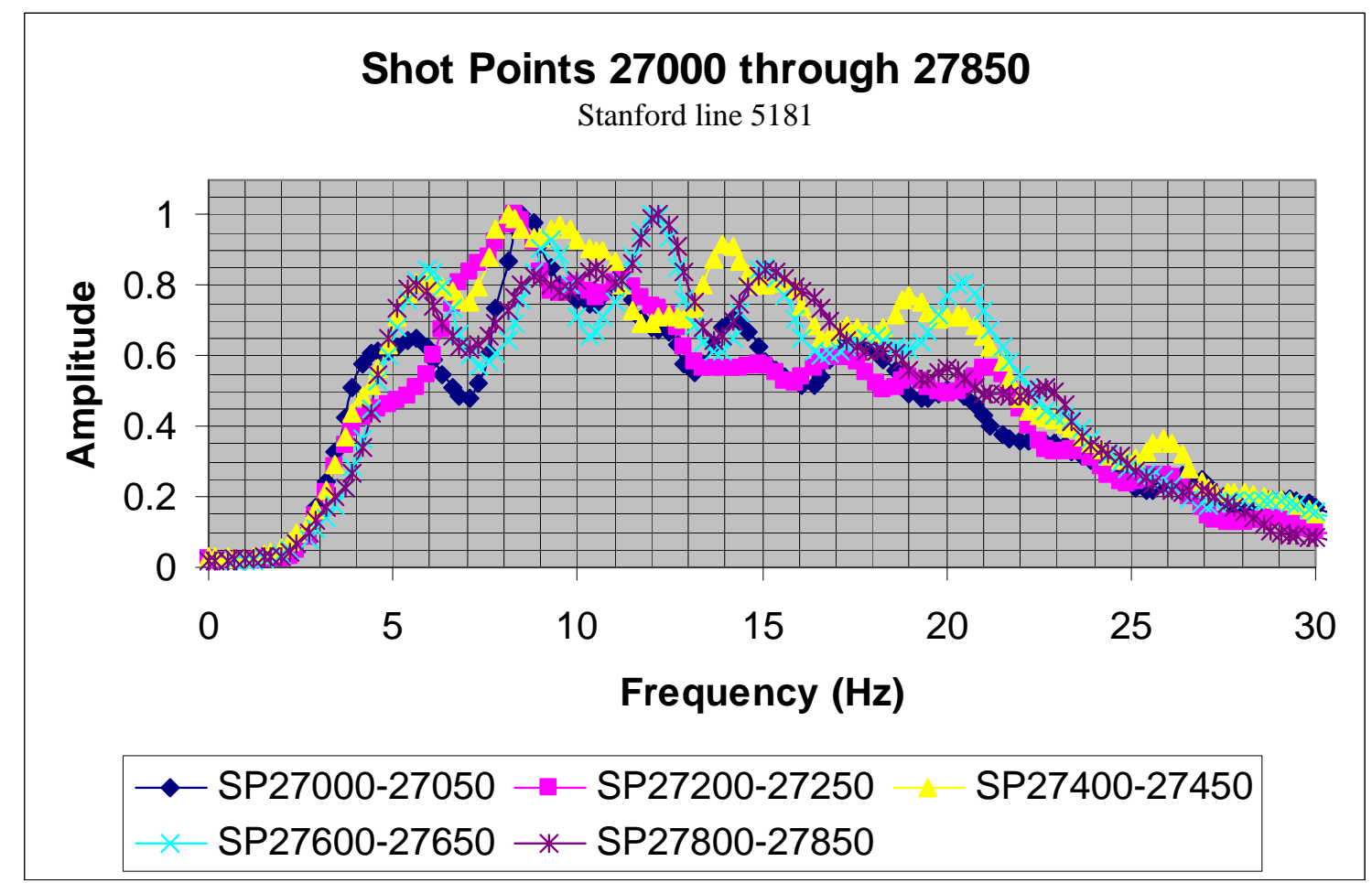

Figure 15: Frequency spectrum for shot points 27000-27850. Each spectrum contains 50 traces and lies between 9 and 13 seconds recording time. Lower numbered shot points are to the Southwest while higher numbered are towards the Northeast. The Herald Arch lies between shot points 25000 and 35000 (figure13).

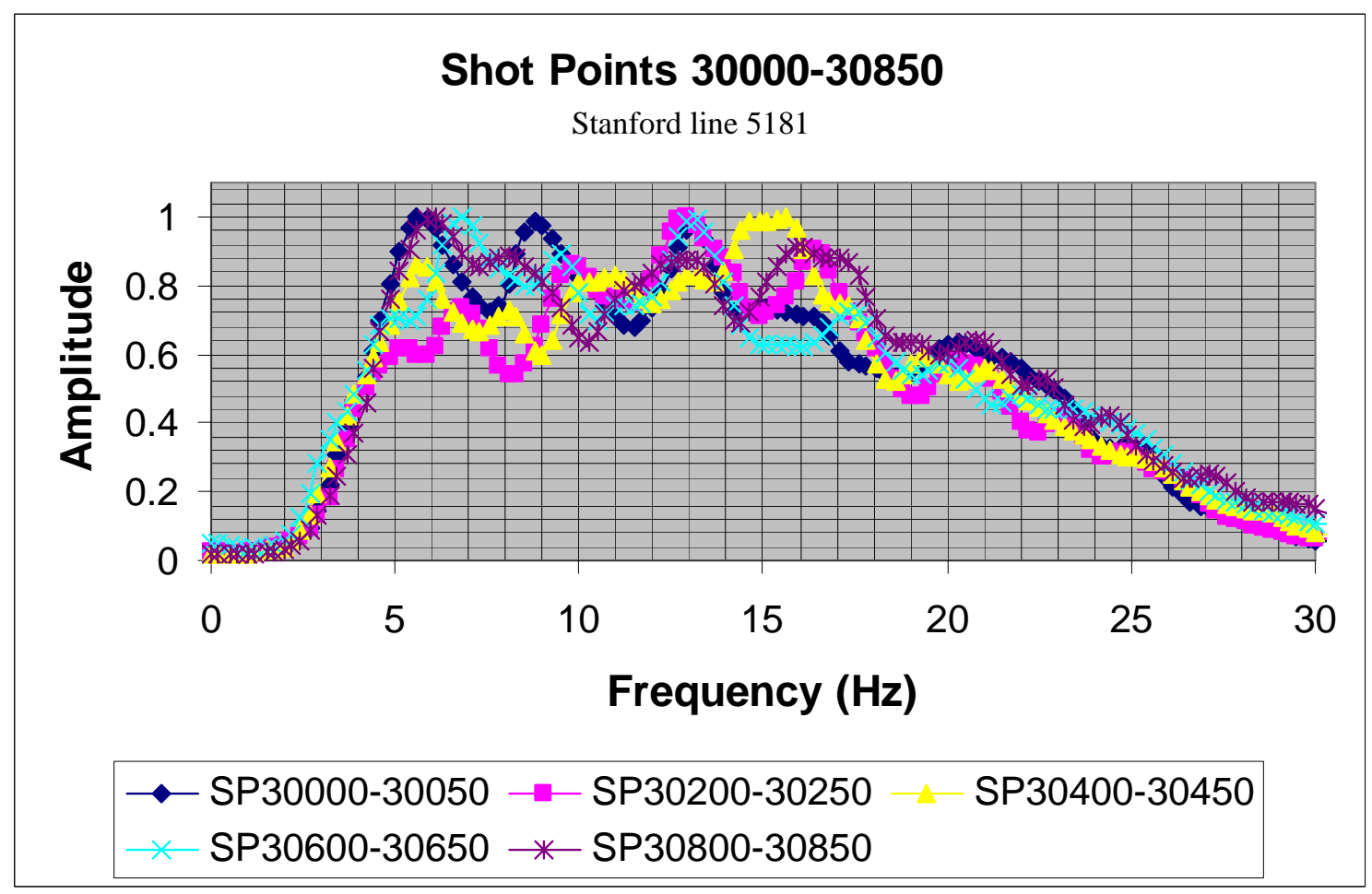

Figure 16: Frequency spectrum for shot point 30000-30850. Each spectrum contains 50 traces and lies between 9 and 13 seconds recording time. Lower numbered shotpoints are to the southwest while higher numbered are towards the northeast. The Herald Arch lies between shot points 25000 and 35000 (figure 13). 
There is a large variety of peak frequencies, between 4 and about $20 \mathrm{~Hz}$, found throughout the data. A single filter for the entire data set was used to focus on the lowest frequency peaks, those between 4 and $12 \mathrm{~Hz}$, in an effort to enhance the deepest reflector which is believed to be the Moho. For nearly all the spectra, the first peak on the spectrum plots between 4 and $12 \mathrm{~Hz}$ with a second peak often falling within this range as well. Several filters were tried with the best results consistently coming from the Butterworth Filter. Other filters, such as the trapezoidal filter, created a blurring effect with little improvement of the signal to noise ratio.

The Butterworth filter uses both high and low cut-off frequencies creating a very smooth bell-like curve with slopes that drop off in $\mathrm{dB}$ per octave. For this data set, a lowpass cut-off frequency of $4 \mathrm{~Hz}$ and a high pass frequency of $12 \mathrm{~Hz}$ was used. This ensured two octaves between the low and high pass filters. The slopes before and after the low and high cutoff frequencies dropped off at $48 \mathrm{Db}$ per octave to help narrow the data field.

Figures 17 and 19 show sections of deep crustal line 5181 in its original, normal processed format. In each of the figures, the Moho is determined by the lowest reflector. Figures 16 and 18 show the same sections after the Butterworth filter has been applied. Between shot points 27000 and 28000, an enhancement of the Moho has occurred after the filtering allowing for a more confident pick of the reflector. For the area between shot points 30000 and 31000, the filtering did little to bring out the Moho reflection. Multiple filters were applied but none made the Moho reflection more discernable than noise. 


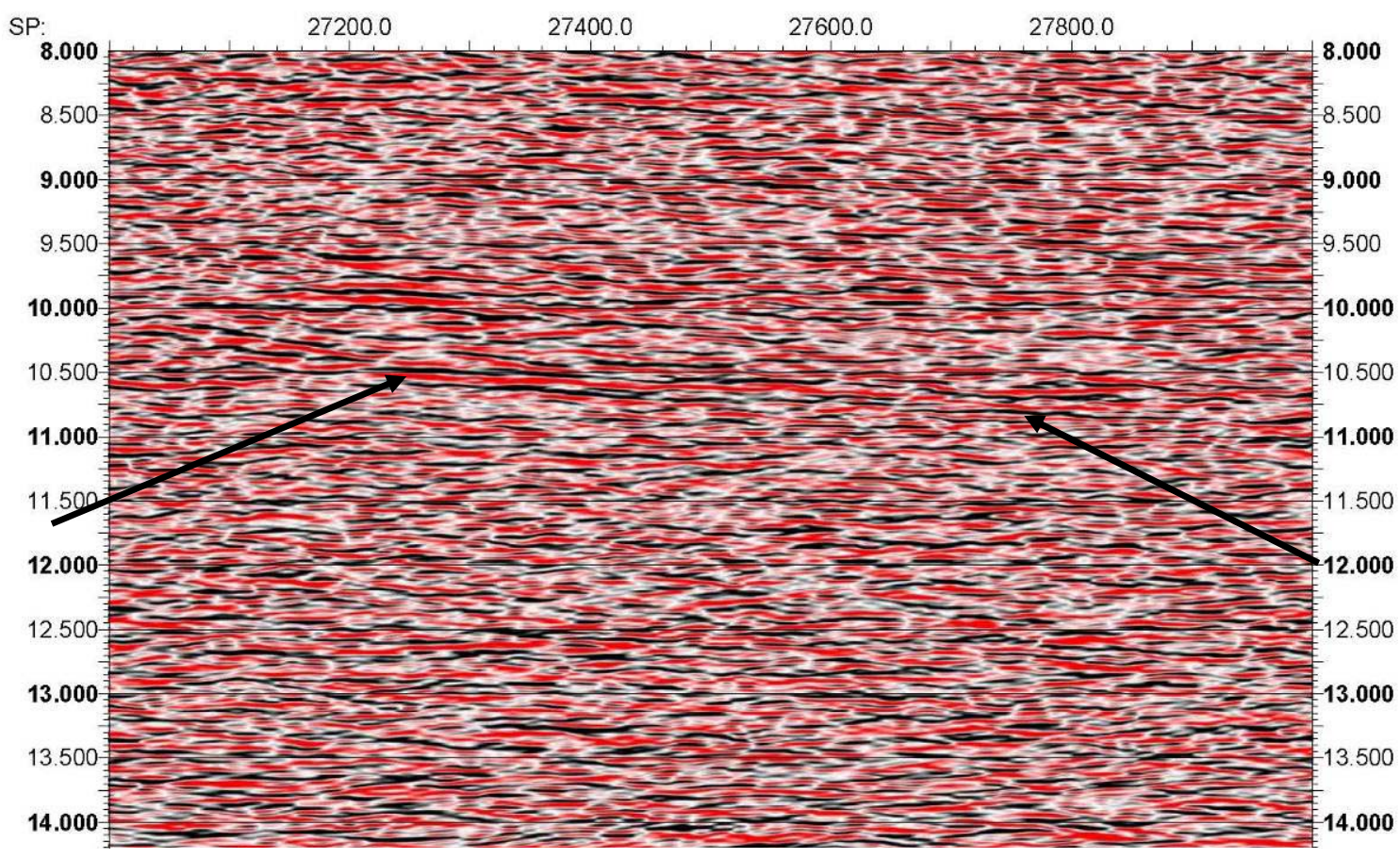

Figure 17: Original data display for shot points 27000-28000 along line 5181. Arrows point to the reflection Moho.

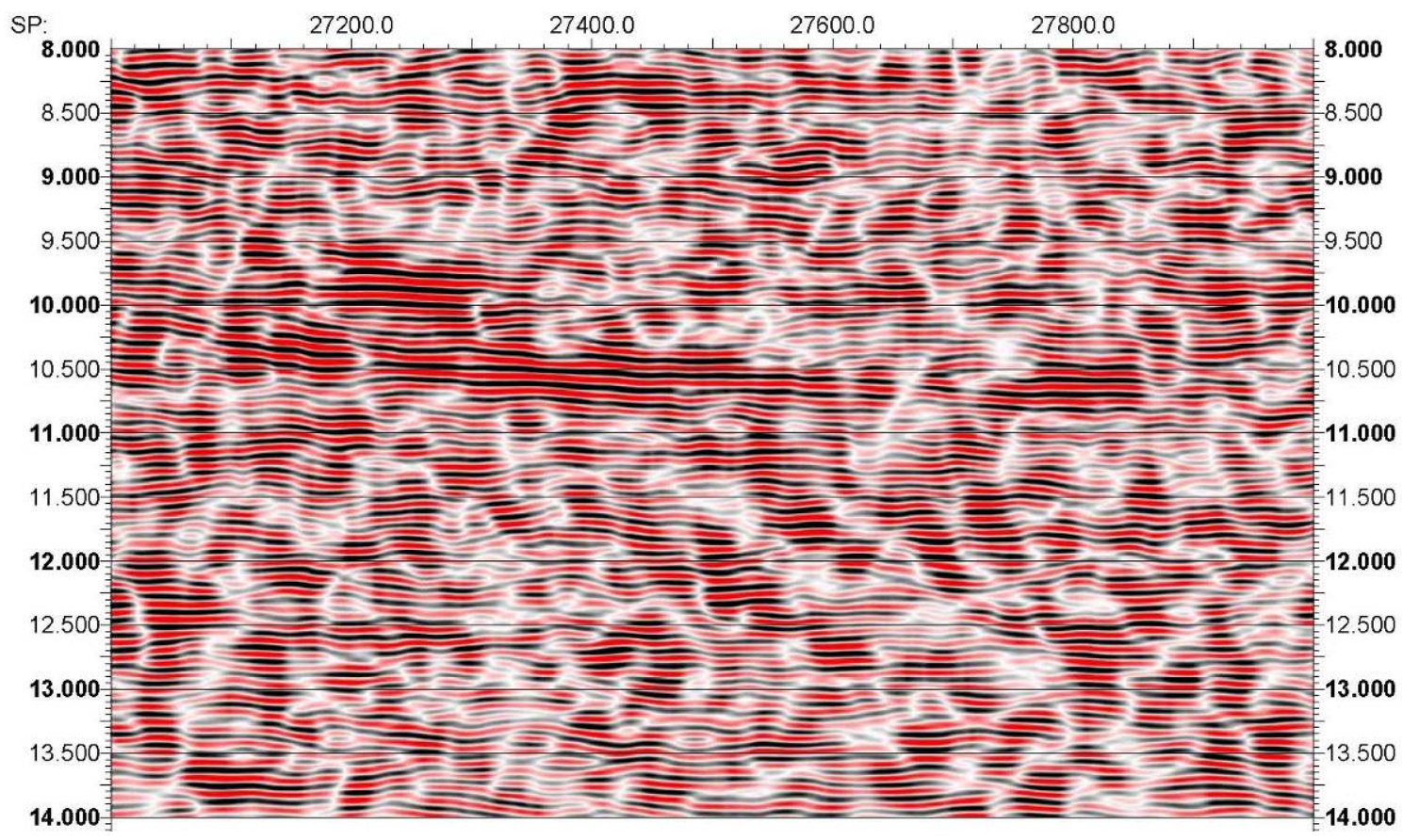

Figure 18: Processed, filtered section of line 5181 between shot points 27000 and 28000. A reflection of the Moho can be seen in slightly greater detail between 10 and 11 seconds. 


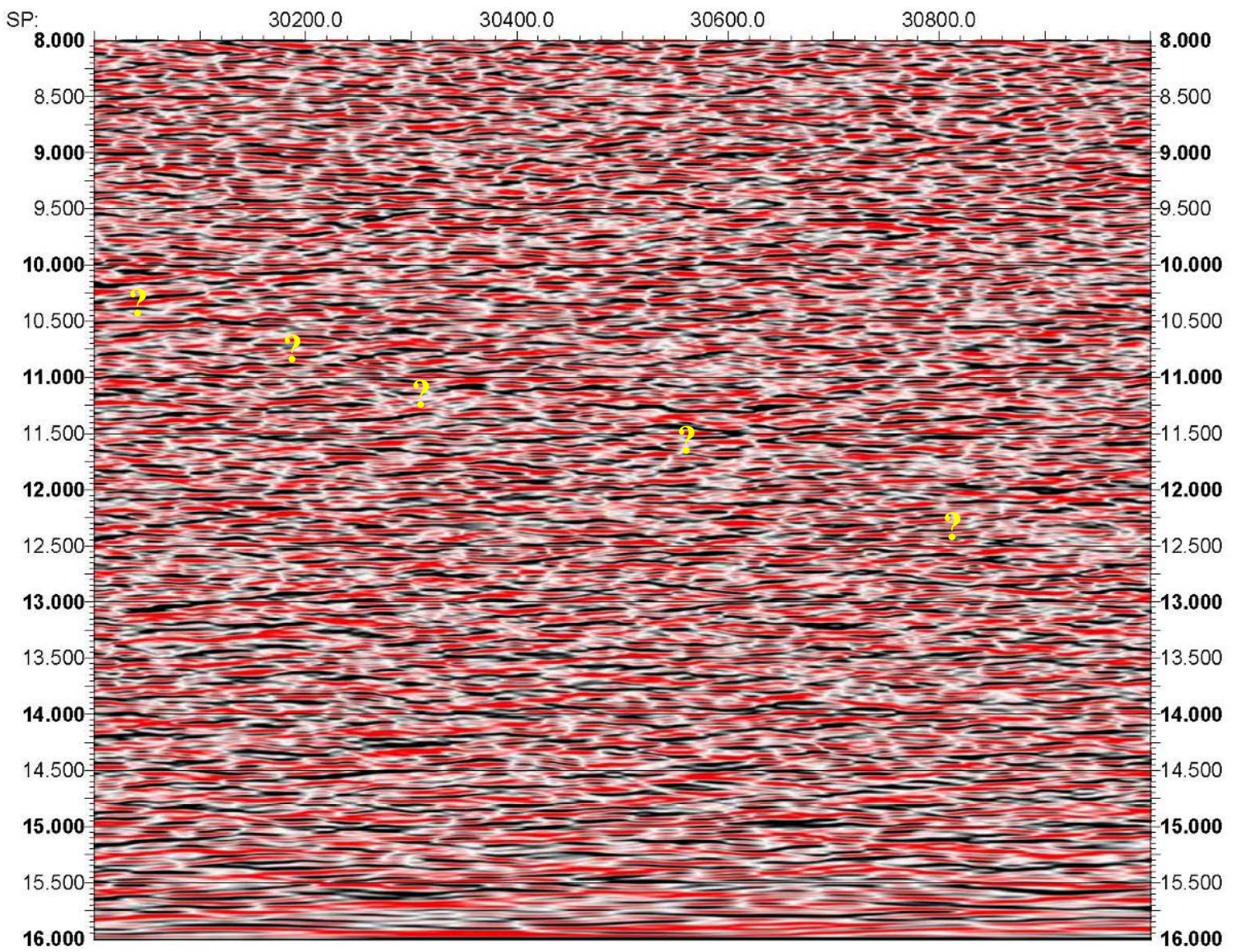

Figure 19: Original data display for shot points 30000-31000 along line 5181. The reflection Moho is unresolvable in this section.

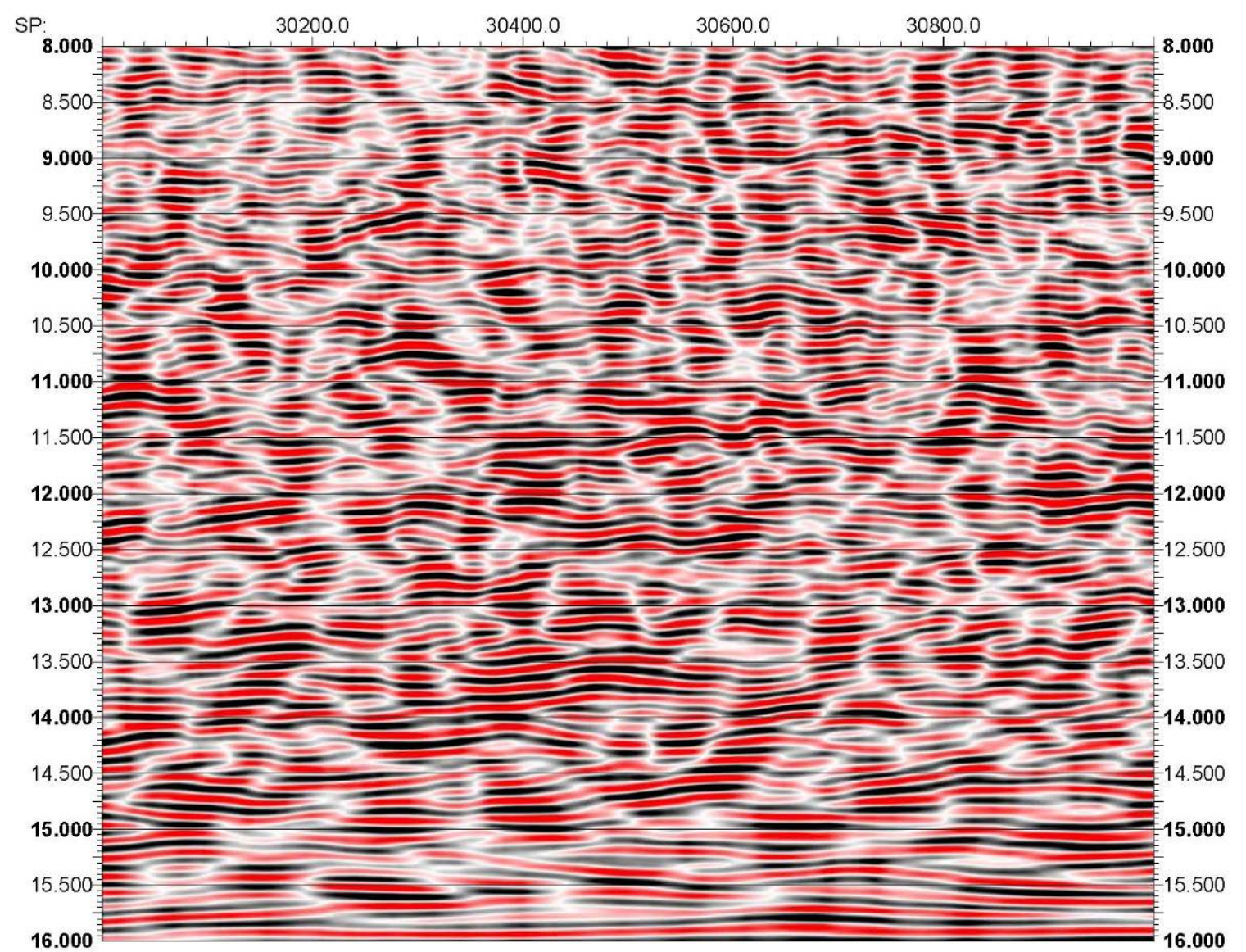

Figure 20: Processed, filtered section of line 5181 between shot points 30000 and 31000.

The Moho remains indiscernible after processing. 
Since the Stanford Deep Crustal lines have already been processed, applying additional filters to them did not always prove to be helpful. The areas where the Butterworth filter had the best results were areas with a Moho reflection already partly visible. The filters increased the signal to noise ratio giving a more convincing reflection and also creating a more laterally continuous reflection. In areas where no reflection could easily be seen, the application of filters did not improve the signal to noise ratio keeping the Moho reflection hidden within the noise.

\section{4: Seismic Interpretations}

The majority of the seismic interpretations were done using the Landmark Geographix software package. SMT Kingdom Suite was only used to filter the Stanford deep crustal lines. Using the few wells in the area and previous seismic studies, especially those of Sherwood et al. (2002), Thurston and Theiss (1987), and Klemperer et al. (2002), ten horizons were interpreted. In ascending order these horizons are; the reflection Moho, basement, Devonian Marker (DM), Mississippian Unconformity (MU), Permian Unconformity (PU), Lower Cretaceous Unconformity (LCU), Brookian 2 (B2), Brookian 1 (B1), Brookian 0 (B0), and an angular unconformity (AU). Figure 2 shows the ten horizons in the eastern-most Stanford deep crustal line and figure 21 shows all the horizons, except the DM and MU horizons.

\subsection{1: Reflection Moho}

The reflection Moho was picked as the deepest reflector on the two Stanford lines (figures 2 and plate 2). This was the most difficult horizon to pick due to its discontinuous reflective nature and the lack of other horizons within a close vertical 
distance for reference. The horizon does show up somewhat clearly in the area just north of the Herald Arch and then again below the Hope Basin. Beneath the major thrust in the Herald Arch area, the reflectors of the Moho become much more intermittent. The additionally processed deep crustal lines, described above, aided in the interpretation. After picking the Moho in the reprocessed Kingdom Suite version, the interpretation was dimported into GeoGraphix to complete the mapping.

The Moho changes in two-way arrival time from an average of about 13 seconds (38 km) in the northern parts of the study area to about 10 seconds (26 km) beneath the Hope Basin (figure 2, plate 2). Most of the thinning occurs between the area just north of the Herald Arch to the junction of the Herald arch and Hope Basin. Minor fluctuations in time are most likely due to the velocity changes in the overlying basin rather than to actual depth changes of the Moho (Klemperer et al., 2002).

A two-way time structure map for the depth to the Moho in time was created from the Stanford Deep crustal lines (figure 22). The Moho is only visible on the two deep crustal lines giving each contour line a maximum of only two points decreasing the confidence of the interpretation especially in the area away from the two seismic lines. These contour maps do show the regional change in thickness of the crust. The deepest Moho is to the northeast of the Herald Thrust with thinning taking place below the Herald Arch. Thinning of about 0.5 second $(2 \mathrm{~km})$ is seen just northwest of the axis of the Hanna trough. This thinning is likely a velocity effect as the slower seismic velocity sedimentary rocks become thinner away from the trough and the faster basement rock becomes thicker. However, a component of this thinning may be contributed by crustal thinning which occurred during the formation of the Hanna Trough. 


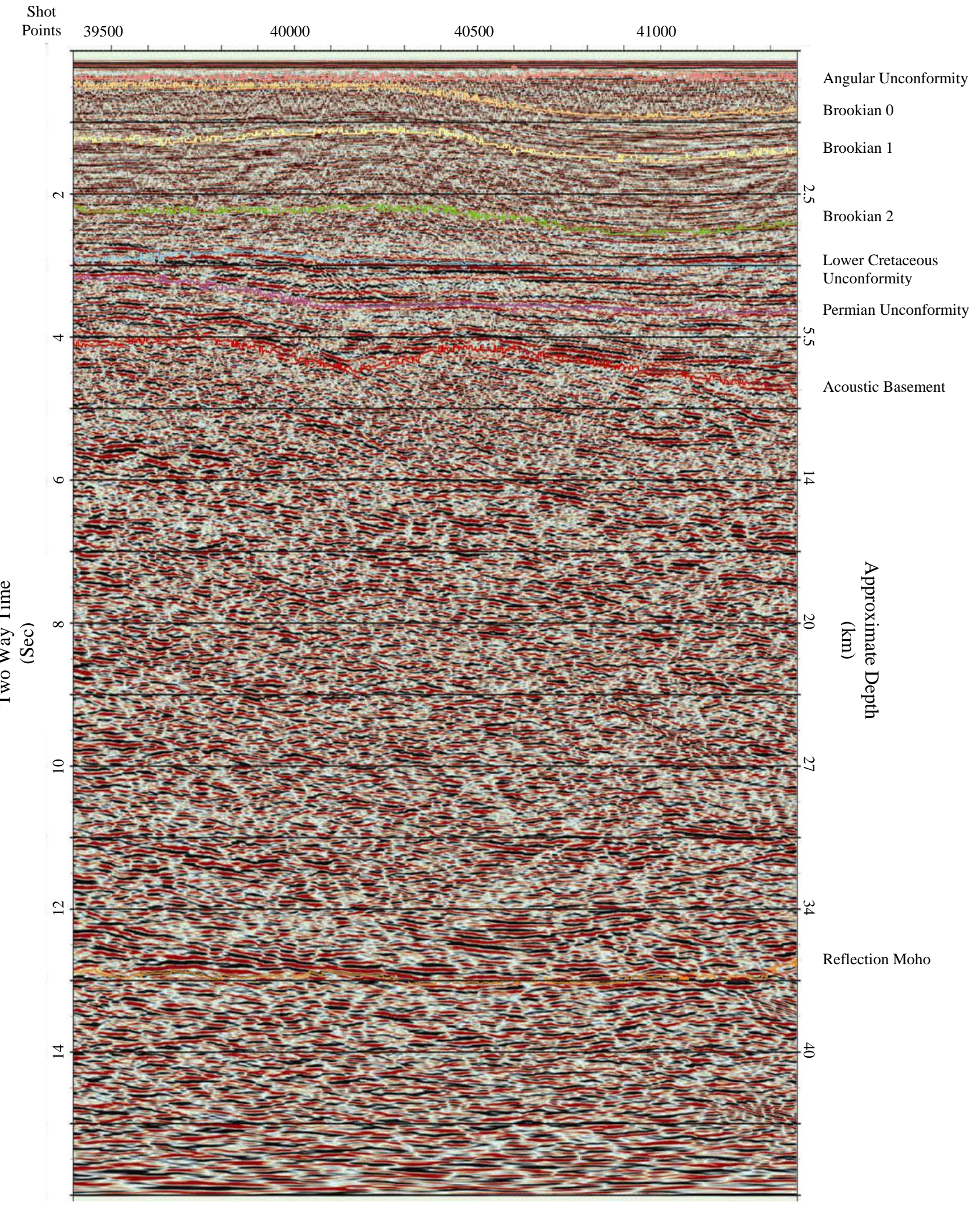

Figure 21: Section of the eastern Stanford deep crustal line 5181. Eight of the ten horizons that were correlated for this study are labeled above. The orange at the base is the reflection Moho, red is the acoustic basement, purple is the Permian Unconformity, light blue is the Lower Cretaceous Unconformity, green is the Brookian 2 horizon, yellow is the Brookian 1 horizon, light orange is the Brookian 0 horizon, and pink is the angular unconformity. See figure 13 for location of the profile. 


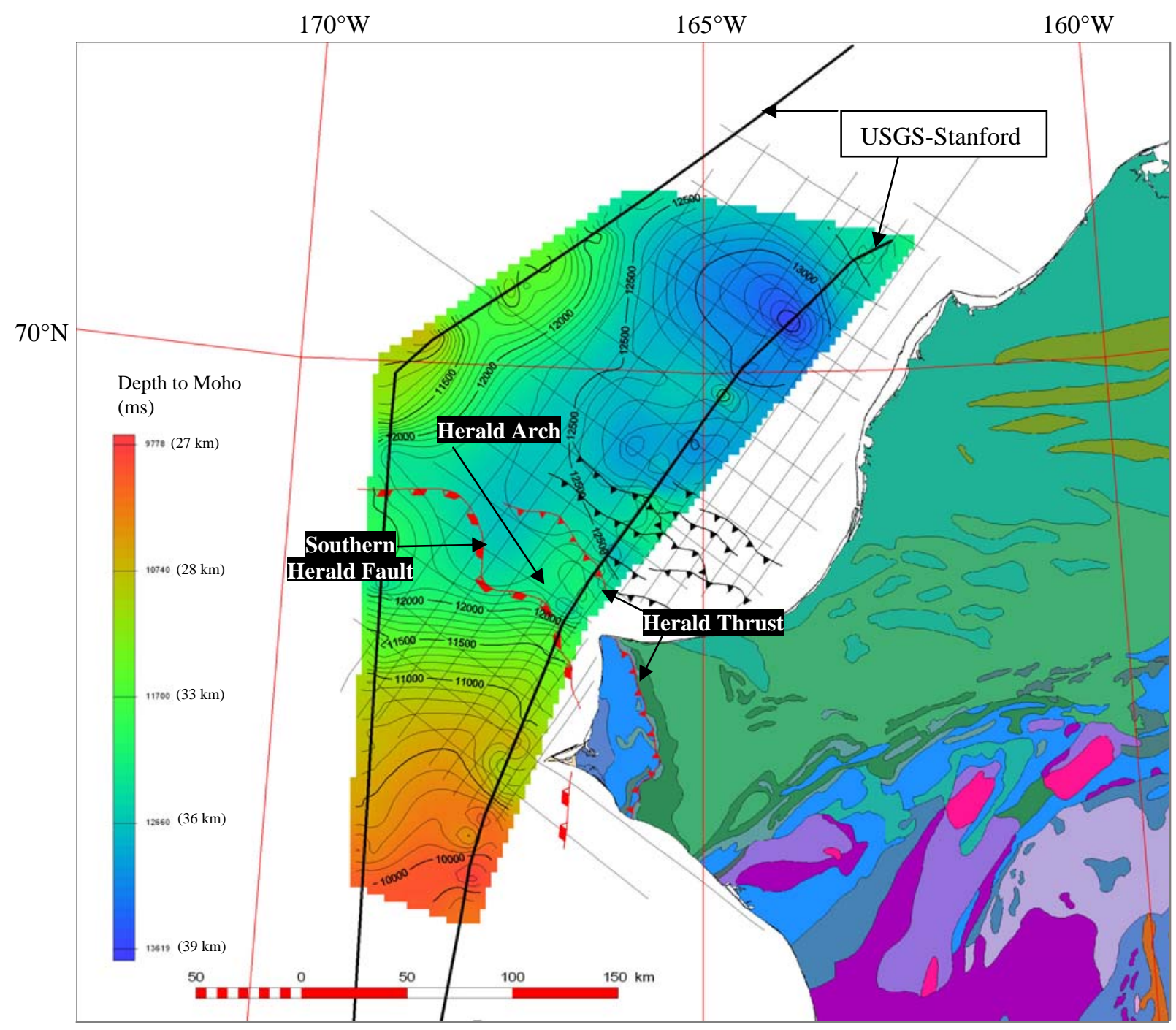

Figure 22: Two-way time structure map showing the depth to the Moho in milliseconds. The two heavy black lines are the Stanford Deep crustal lines and provide the only data points for the contour map. Crustal thinning can be seen as the Moho changes from a depth of about $40 \mathrm{~km}$ in the north east, to a depth of about $27 \mathrm{~km}$ in the south. 


\subsection{2: Basement}

The basement was picked as the last strong and continuous reflector on the two shallower (maximum of 6 seconds deep) seismic data sets (figure 21) and the last reflector before reaching the thick basement section for the deep crustal lines. The acoustic basement to the north of the Herald Arch is not the same basement rock below the Hope Basin. In the area to the north, below the Colville Basin, the acoustic basement rock is believed to be Franklinian (early Paleozoic) (Herman, et al. 1992) but below the Hope Basin near the Herald Thrust, the acoustic basement includes the deformed Brookian and Ellesmerian sequences (Decker et al., 1988). For most of this study, the basement in both areas was usually mapped as a single unit representing the last clear reflector to emphasize the Herald Arch and Thrust.

Two-way travel time to the basement reflector ranges from nearly 6 seconds (approximately $13 \mathrm{~km}$ deep) in the northeast around the Colville Basin to near the base of the sea floor at the edge of the Hope Basin where the Herald Thrust begins (figure 23 and plates 1-3). The basement becomes shallower moving away from the shore towards the northwest and to the southwest towards the Hope Basin (figure 24). Figures 26 A, B, and C show seismic lines 132, 118, and 104. This series of lines demonstrates the shallowing

of the basement moving from the southeast to the northwest in the region just to the north of the Herald Arch. 


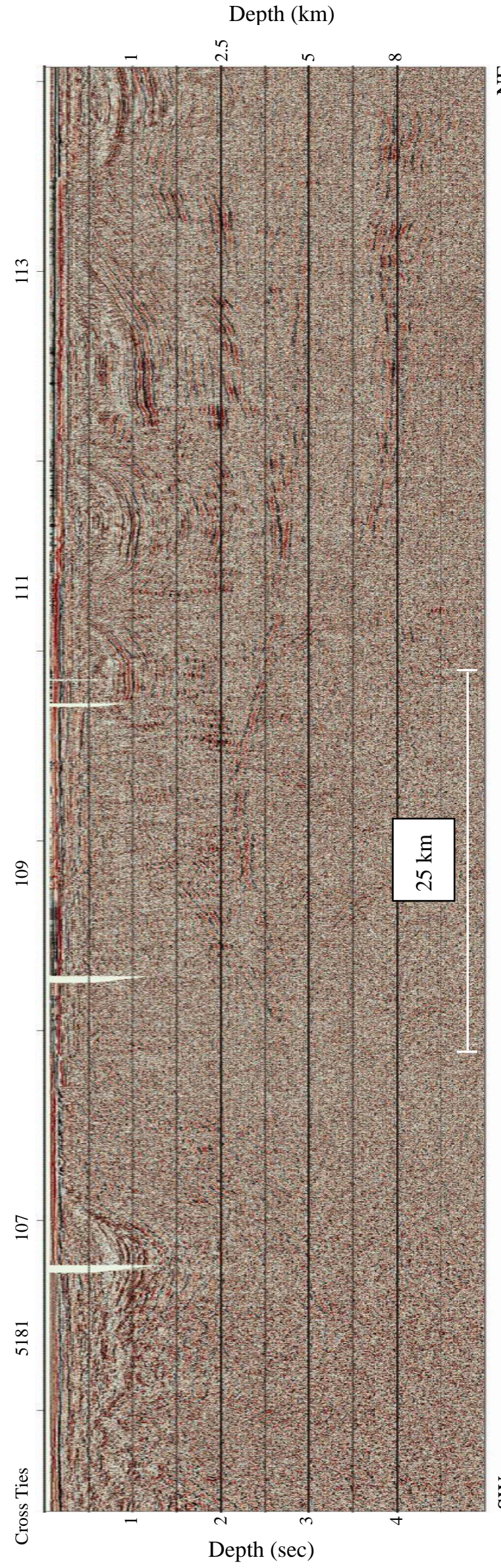

Depth $(\mathrm{km})$
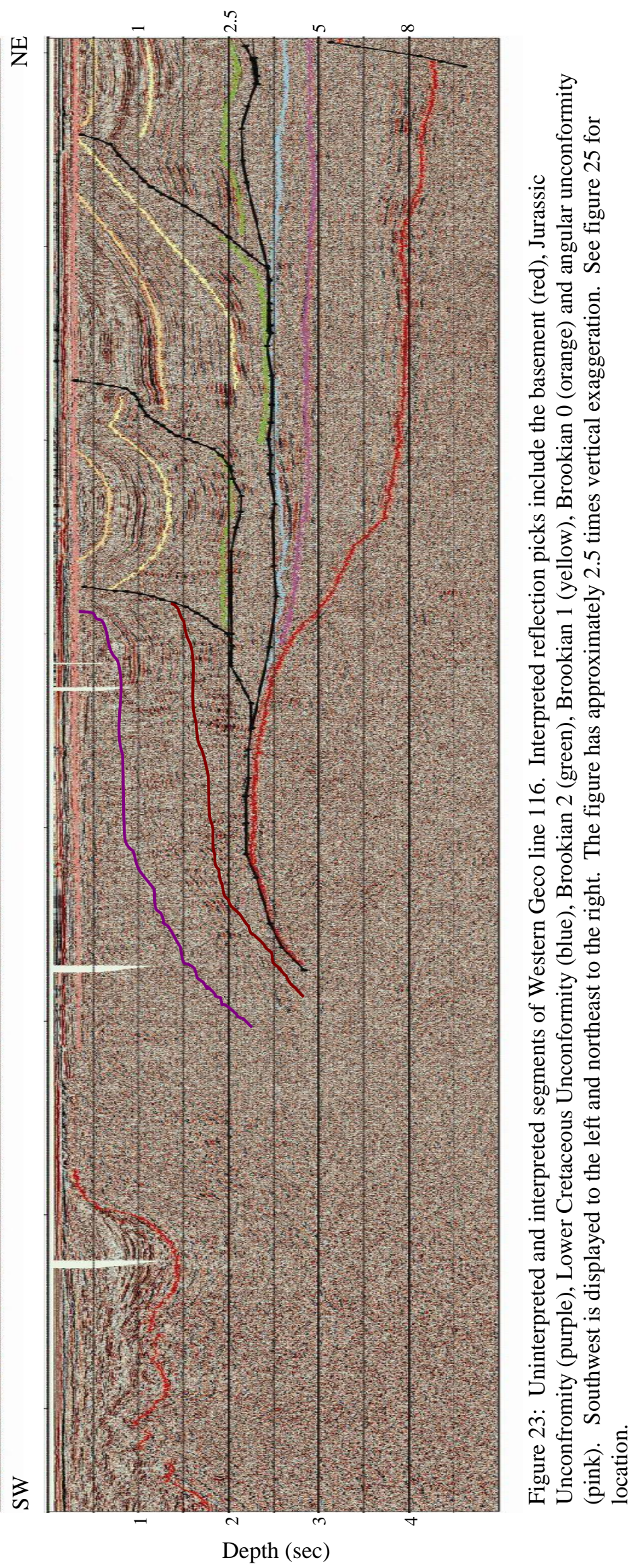


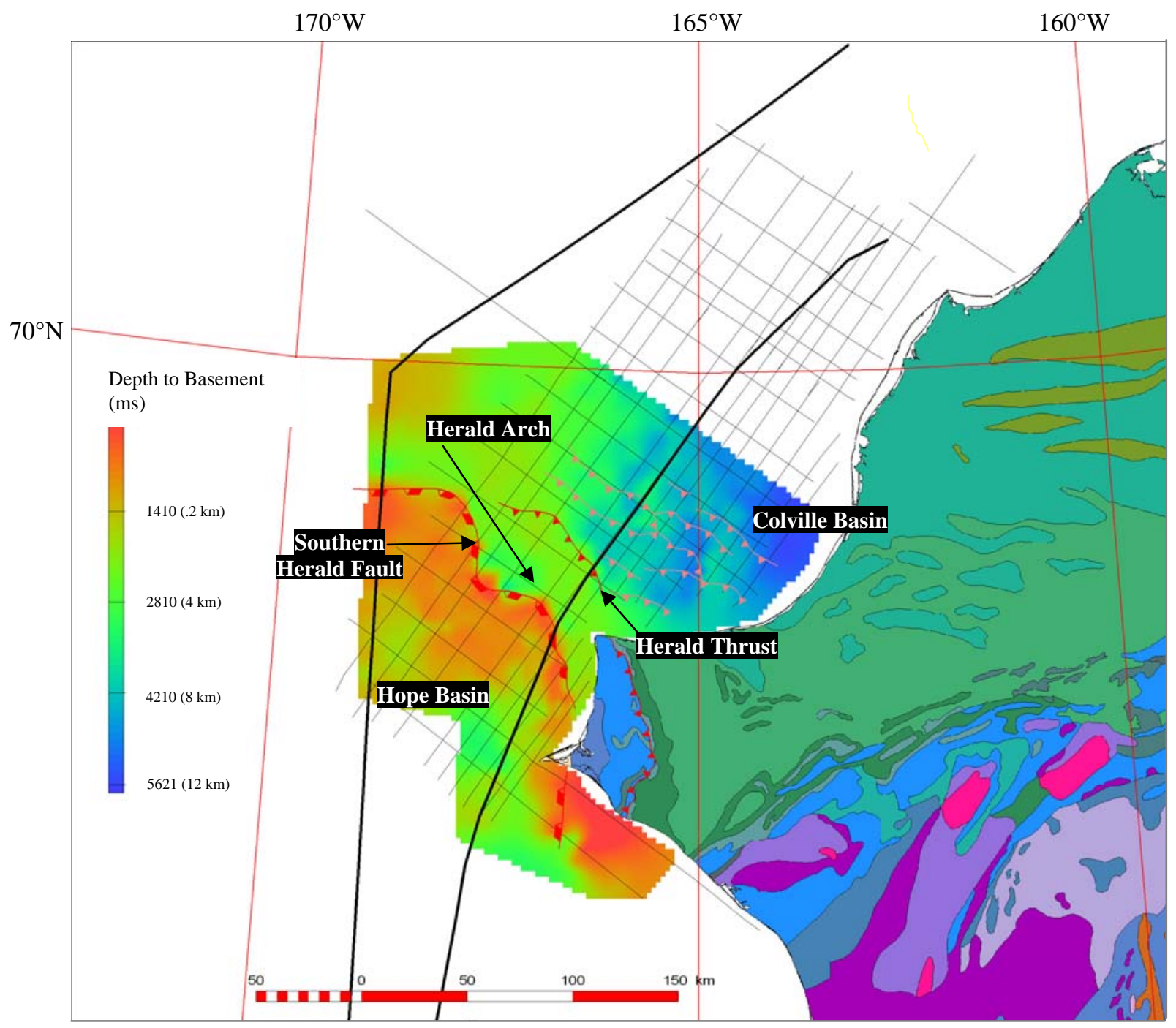

Figure 24: Map showing interpreted two-way travel time map to basement. Cool colors represent a deep basement while warm colors are shallow. Basement rock to the northeast, Colville Basin and Hanna Trough, is deep (5.6 seconds) and the basement along the Southern Herald Fault is at the seabed. The line along which the basement reaches the surface is interpreted as the Southern Herald Fault. 


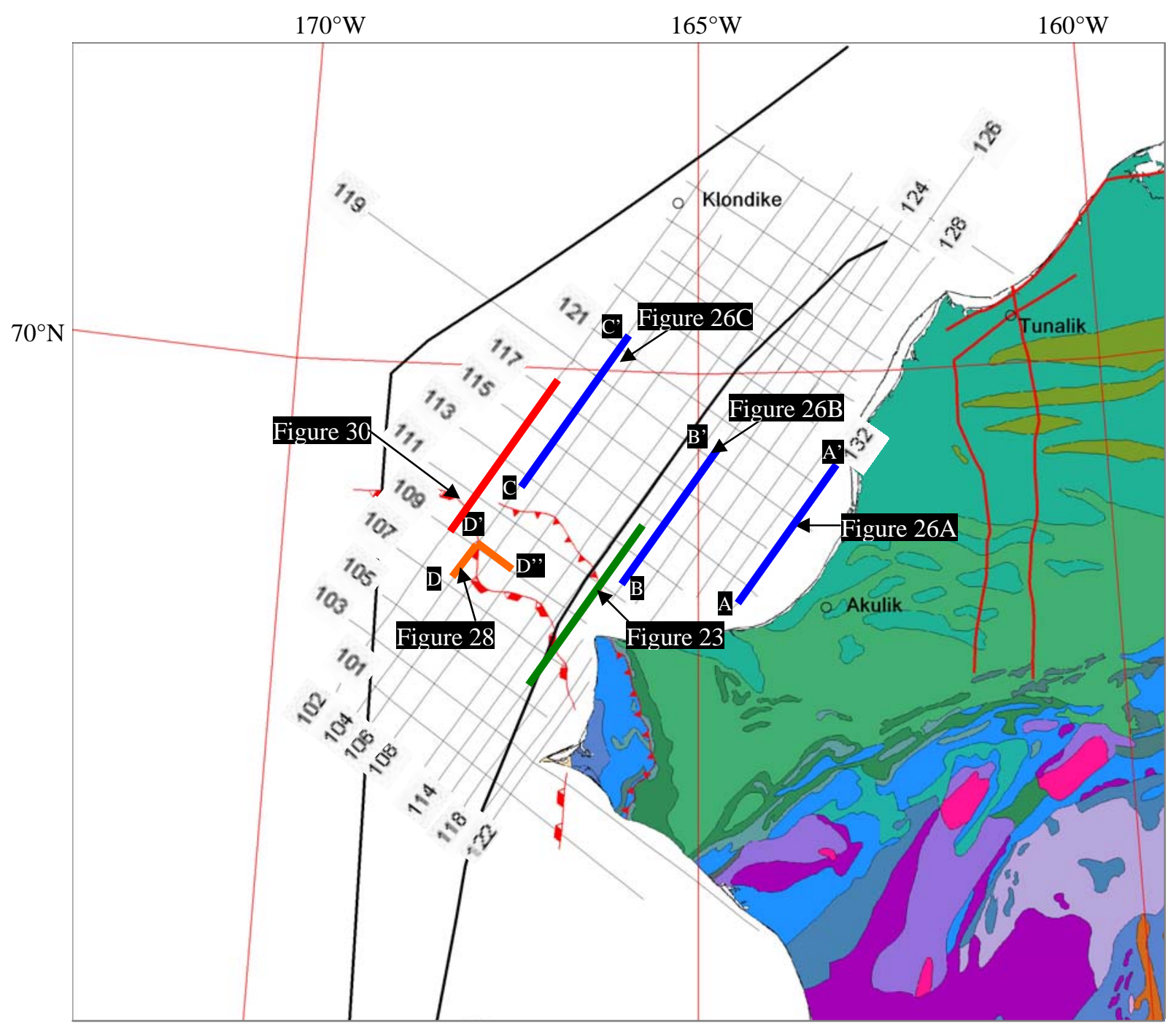

Figure 25: Location of seismic profiles for figures 23, and 26. Heavy black lines are the ship tracks for the USGS-Stanford survey, light black lines are for the Western Geco survey (WGS). The green line shows the location of the seismic profile in figure 23 Along line WGS 116. The blue lines show the locations for figures 26A, 26B and 26C, lines WGS 132, WGS 118 and WGS 104 respectively. The orange line is the location of figure 28 showing the mis-tie of WGS 104 and WGS 109. The red line is the location of figure 30 showing WGS 102. 


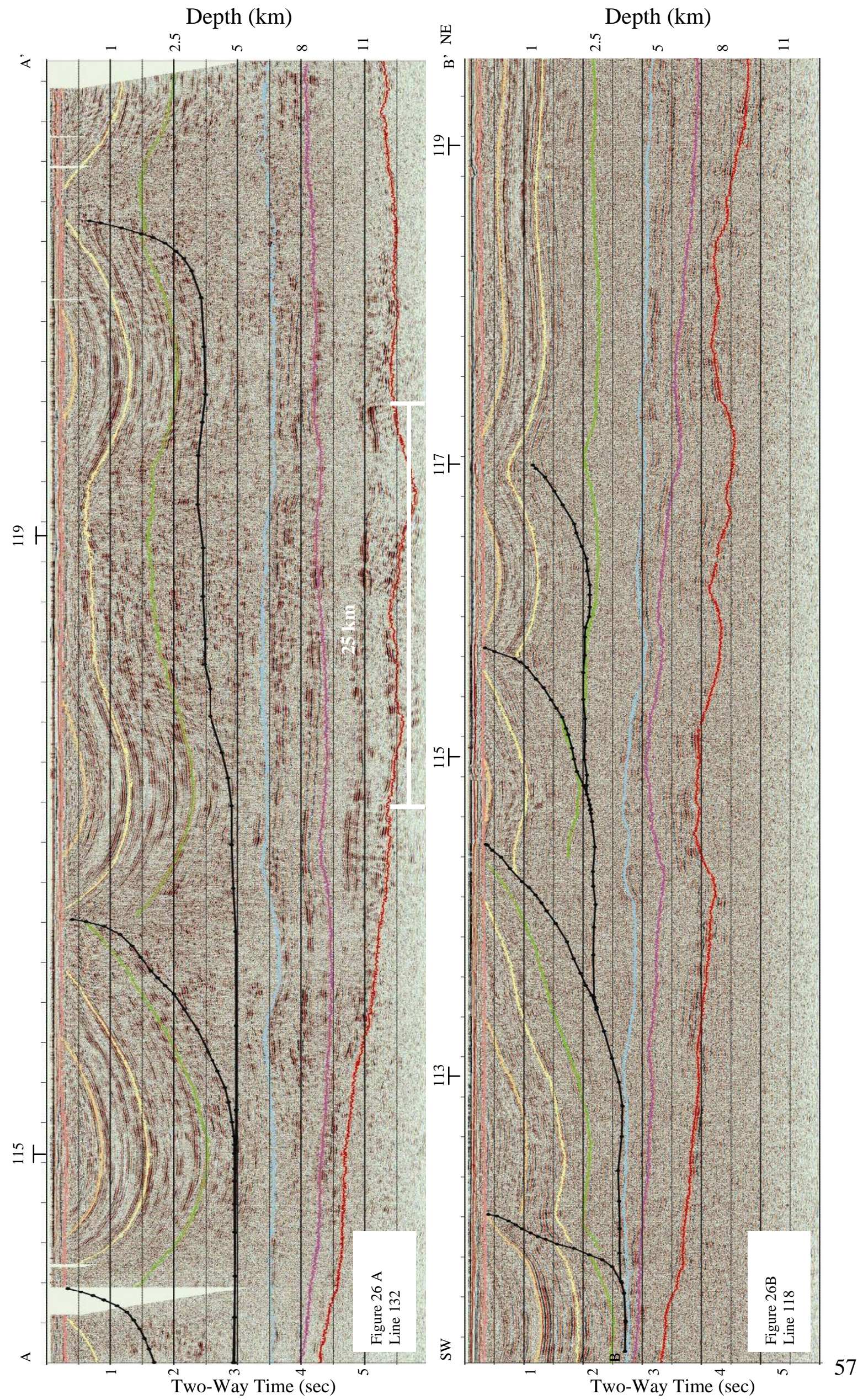




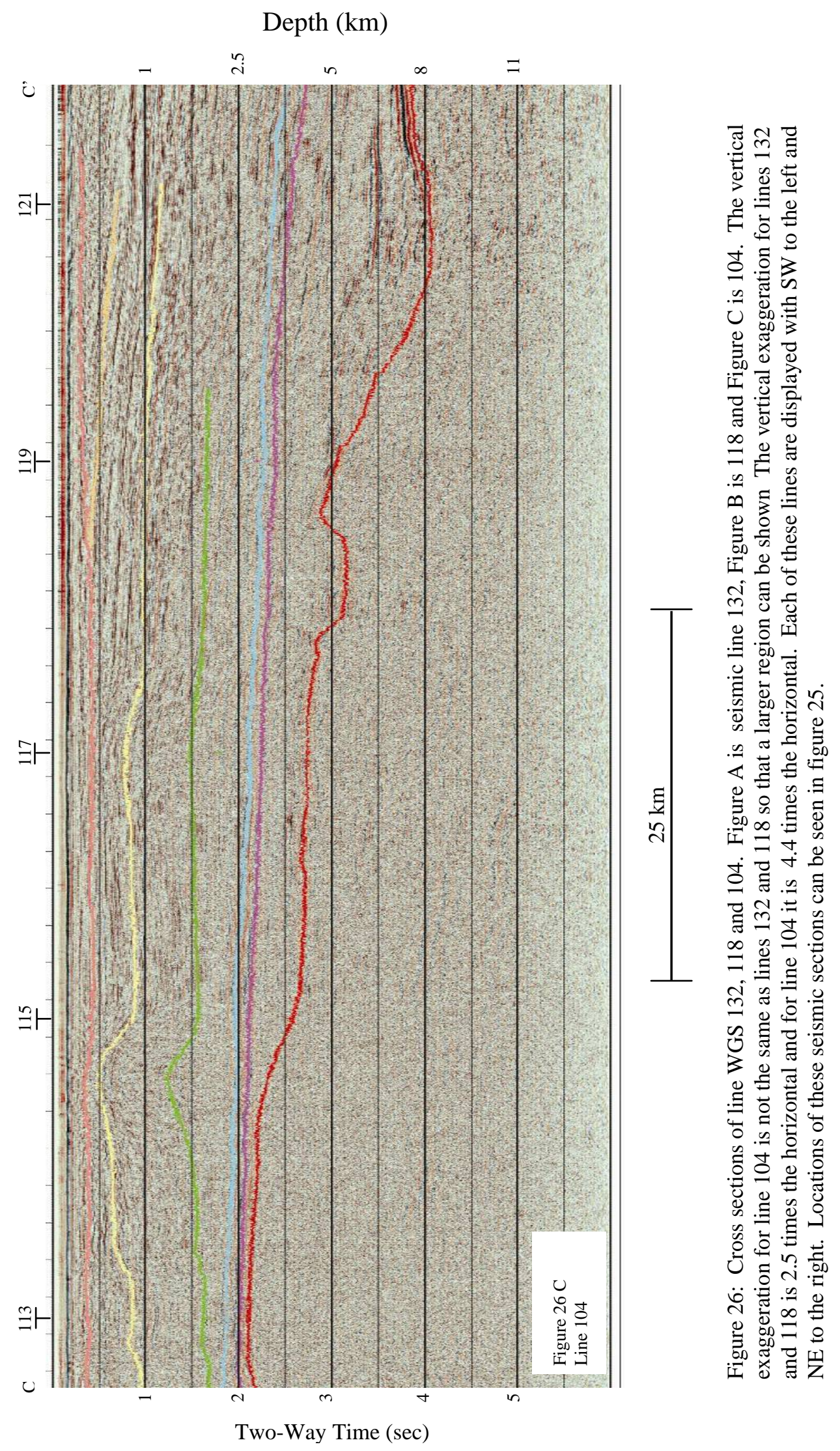




\subsection{3: Permian and Lower Cretaceous Unconformities}

The Permian (PU) and Lower Cretaceous Unconformities (LCU) were interpreted based on well data from the Tunalik and Klondike wells along with previous seismic interpretations from Sherwood et al. (2002). The LCU horizon, and all those below, are below the detachment of the Brookian thrust faults. The double reflector that marks the LCU (blue horizon) was easy to correlate from previous seismic studies to this study area (figure 2, plates 1-3). The Permian Unconformity (purple line) lies between 0.2 to 1.8 seconds $(0.2-2 \mathrm{~km})$ below the LCU in the north and northwest sections of the study area. As the horizon is traced to the south and southwest, it merges into the LCU as it onlaps the sag phase normal fault, at the edge of the Hanna Trough (figure 23).

This study focused on the LCU horizon because it could be correlated farther, across the Herald Arch, and was also more easily recognized and could be picked with greater confidence. Figure 27 is a two-way time structure map to the LCU with the overlying fault traces. This horizon lies between 3.5 and 2.0 seconds two-way travel time with the deepest parts towards the east, closest to shore, and the shallowest to the west, moving away from the basin. Along individual seismic lines that run southwestnortheast, the horizon is nearly flat lying with only minor changes in depth. Seismic profiles that run southeast-northwest show the horizon gently shallowing towards the northeast. Picks of the LCU beyond the western edge of the Hanna Trough are difficult as the Brookian Sequence and LCU converge in that area. 


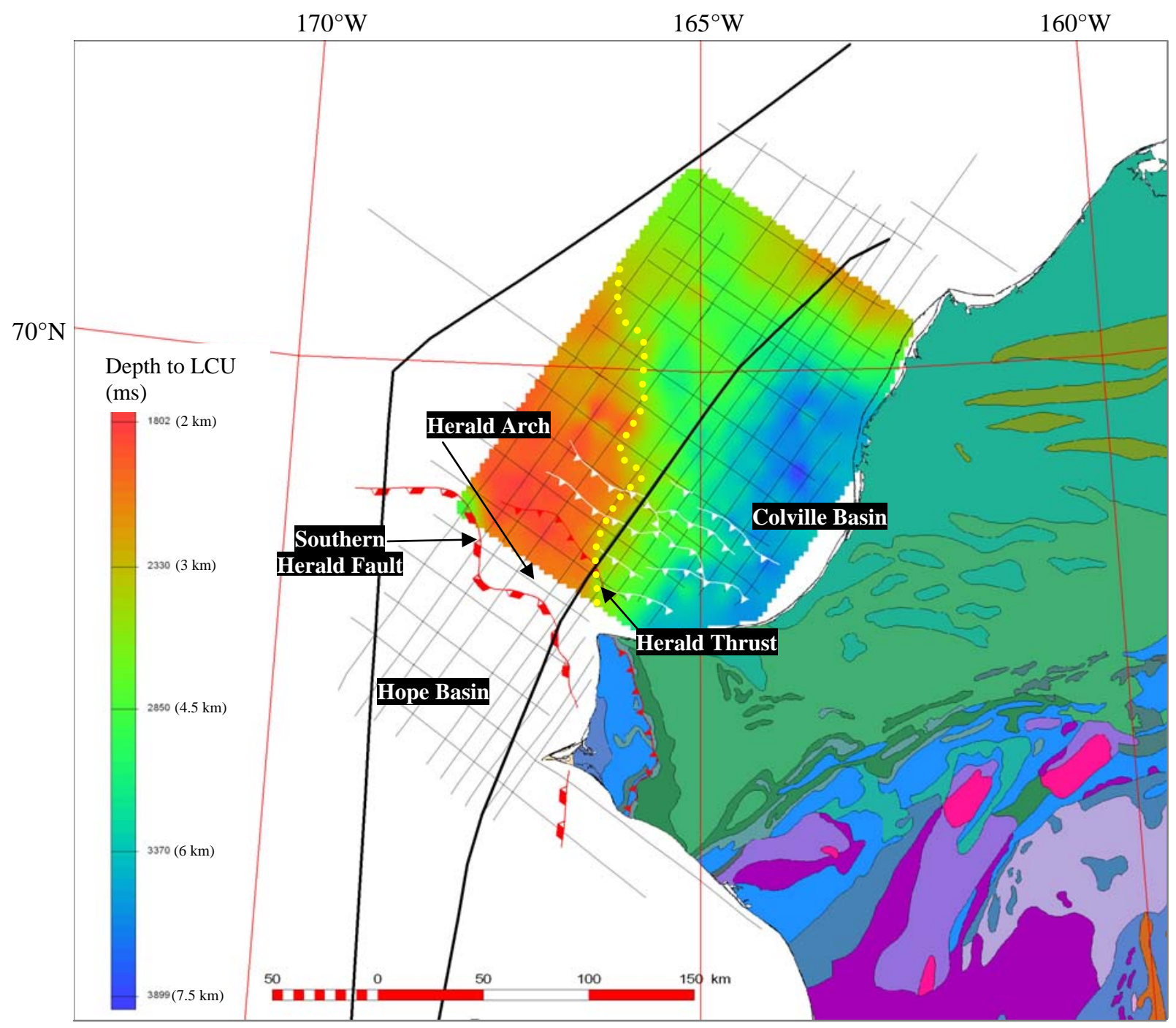

Figure 27: Two-way time structure map of the LCU horizon. Red areas represent a shallower LCU and the blue areas represent a deep LCU. The deepest parts of the LCU are along the axis of the Hanna Trough in the Colville Basin. The LCU becomes shallower to the west and southwest, approaching the western edge of the Hanna Trough. Yellow dashed line marks where the base of the Brookian Sequence converges with the LCU and differentiating between the two became difficult west of the line. 


\subsection{4: Brookian Horizons and Angular Unconformity}

Brookian 2 (B2), Brookian 1 (B1) and Brookian 0 (B0) were chosen for their continuity and strong reflection characteristics (figure 21) and make up nearly all of the 3 $\mathrm{km}$ thick Brookian sequence. These horizons were among the best reflectors that did not diverge and merge into reflectors above and below on the seismic data. No specific formation or lithologic unit has been tied with them but it is assumed that these reflectors maintain approximately the same age for the area (Tearpok et al., 2003). The youngest reflector, the Angular Unconformity (AU) was picked as the line which the thrust faults terminated into a thin section of horizontal beds. The age of this reflector is uncertain but is cut by the normal faults of the Hope Basin and is thus believed to be older than the Hope Basin margin. This reflector, unlike the LCU through B0 horizons, was traced nearly to the edge of the Hope Basin.

These horizons were picked in loops in an attempt to increase the accuracy and consistency of the picks. However, there are numerous mis-ties between the 2-D seismic lines (figure 28), along with the major thrust faults that cut through the Brookian reflectors. Two-dimensional seismic data frequently has this problem, especially on seismic lines that closely follow the strike and dip of structural features (Tearpock et al., 2003), as this seismic data set does. The mis-ties are normally minor, less than 0.25 second, and the seismic character of the reflectors increases the confidence in picking the Brookian horizons.

The Brookian reflectors are cut by numerous thrust faults with displacements of 0.2 to 2 seconds $(0.2-3 \mathrm{~km})$ (figures 2, 21, and plates). The greatest offsets are located between lines 118 and 106, the area closest to the Herald Thrust (figure 25). To the 
northwest, the fault throws diminish until they are no longer present on the northwestmost seismic line, 102 (figure 30). To the southeast, heading landward, the thrust faults become steep synclines occasionally cored by a thrust with little offsetting of units observed. The horizons in this section were easier to trace than those closer to the Herald Thrust because of their stronger reflection characteristics and the lack of major thrusts cutting through the sections.

The Brookian horizons lie in the upper 2.5 seconds on the seismic lines, with the Brookian 2 averaging 2.0 seconds (2.5 km) deep, Brookian 11.0 to 1.5 seconds (1-2 km deep), and Brookian 0 never going below 1.0 second (1 km deep). Figure 29 is a twoway time structure map of the Brookian 1 horizon. This middle of the three Brookian horizons was chosen because it best shows the changes in depths of the reflectors throughout the region and also helps to show where the thrust faults and synclines are located.

Interpreted faults and syncline-anticline features have a northwest strike nearly parallel to the Herald Thrust. Onshore, it appears that they bend to a east or northeast strike. Offshore, the folds have a consistent wavelength of approximately $15-20 \mathrm{~km}$ (figure 31). Both sides of the thrust have approximately the same dip angle making the folds appear symmetrical.

The Brookian horizons start nearly planar along line 102 (figure 30) to the northwest and progressively become more deformed moving to the southeast (figure 26 C, 26B then $26 \mathrm{~A}$ and plates 1-3). The flat lying horizons become faulted by reverse faults before becoming steep anticlines and synclines onshore. The greatest 
concentration of faults occurs along line 116 where five major thrusts, with more than 0.2 seconds displacement, were mapped along a $5 \mathrm{~km}$ section (plate 3).

Reconstructions were made of each of the southwest-northeast trending lines to evaluate the amount of shortening that took place. This was done in two stages, one that includes only the Herald Thrust, and a second that includes all the faults, except the Herald Thrust. Table 1 shows a comparison of each of the northeast striking seismic lines and their respective shortening percentages for the Herald Thrust and the nonHerald thrusts. Line 102 was omitted because there were no major faults visible, including the Herald Thrust. The greatest amount of shortening in the Brookian rocks took place along line 116 being shortened to $82 \%$ of its predeformational length. The shortening decreases to the north and south of this line reaching nearly $0 \%$, no shortening, at the northwestern edge of the study area and about $5 \%$ to the southeast. From line 118 to 132, however, the seismic lines do not extend to the Herald Thrust possibly causing some major thrusts to be missing from the calculations. The differences in the Brookian 1 and 2 can be attributed to missing sections of the line due to erosion cutting the tops of the thrust and anticlines along the angular unconformity.

When the Herald Thrust is treated separately, there is no gradual change in the amount of shortening moving from southeast to northwest as there is for the Brookian Horizons. Each of the reconstructions showed approximately the same amount of shortening, between $37 \%$ and $43 \%$. Seismic line 112 , only $21 \%$ shortening, contains many data gaps over the area of the Herald Thrust causing difficulty in precisely determining the location of the fault. 


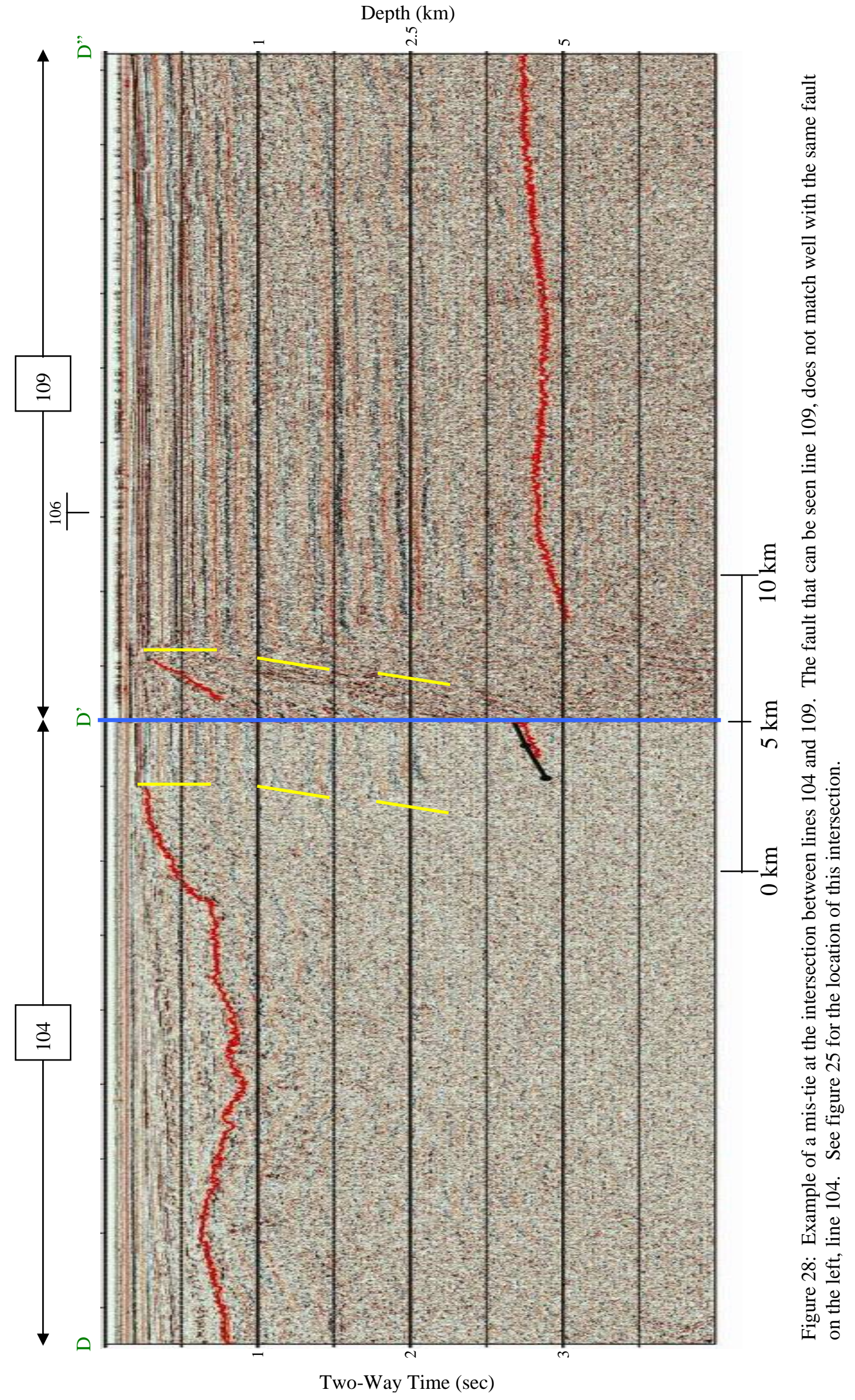




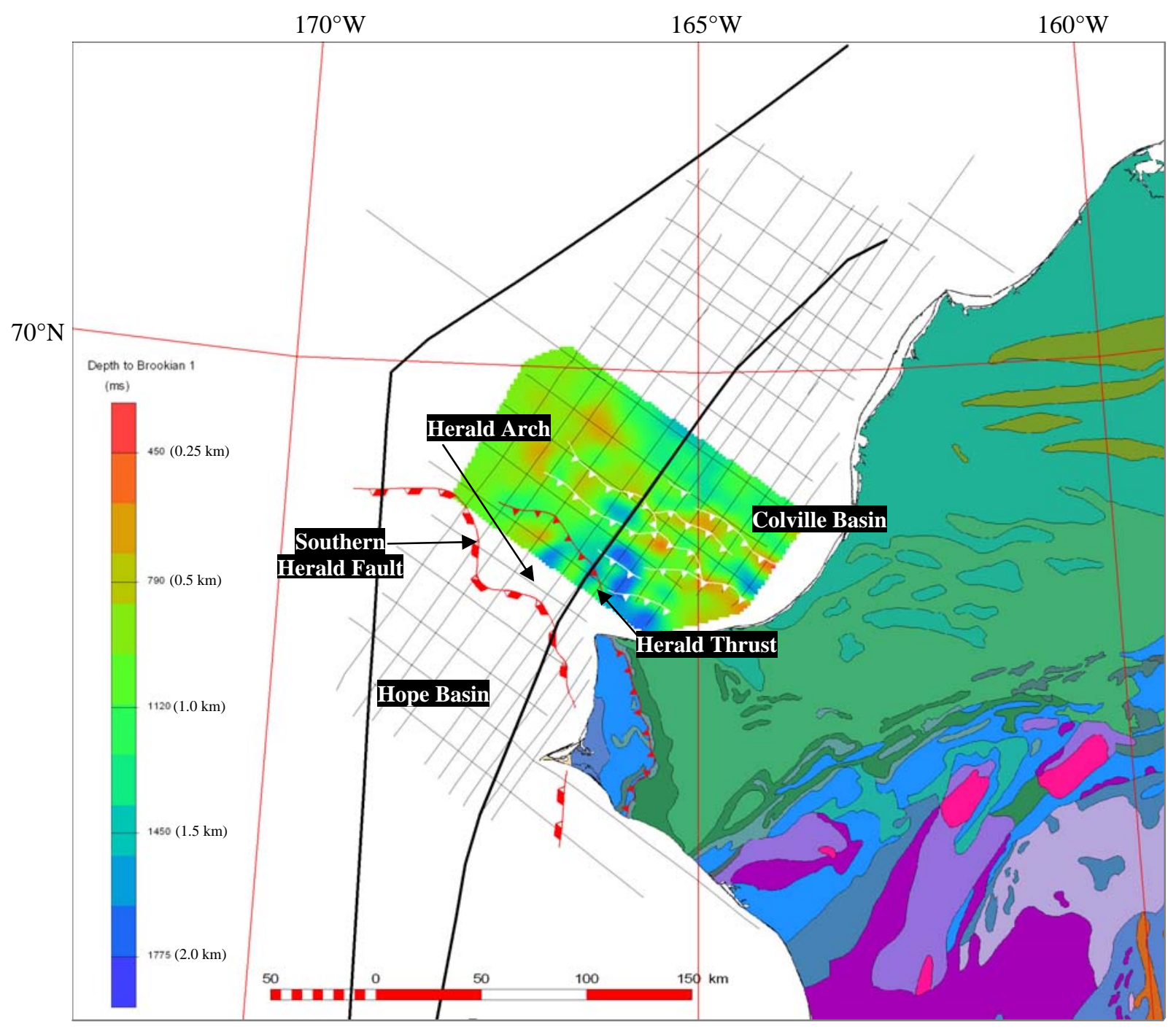

Figure 29: Two-way time structure map showing of the Brookian 1 (B1) horizon. Warm colors are shallow and cool colors are deep. The white thrusts are the Brookian thrusts with the arrows on the hanging wall. 


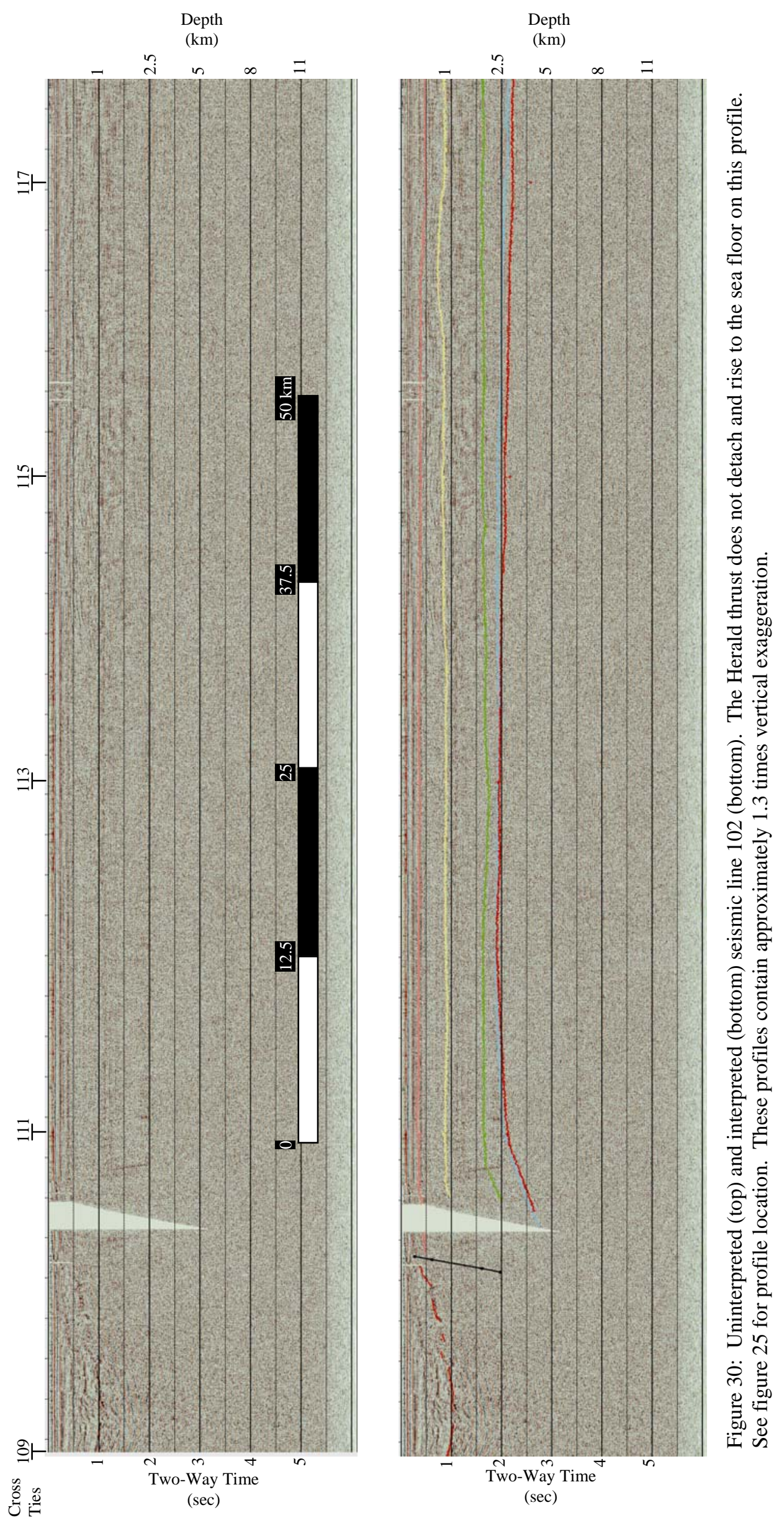




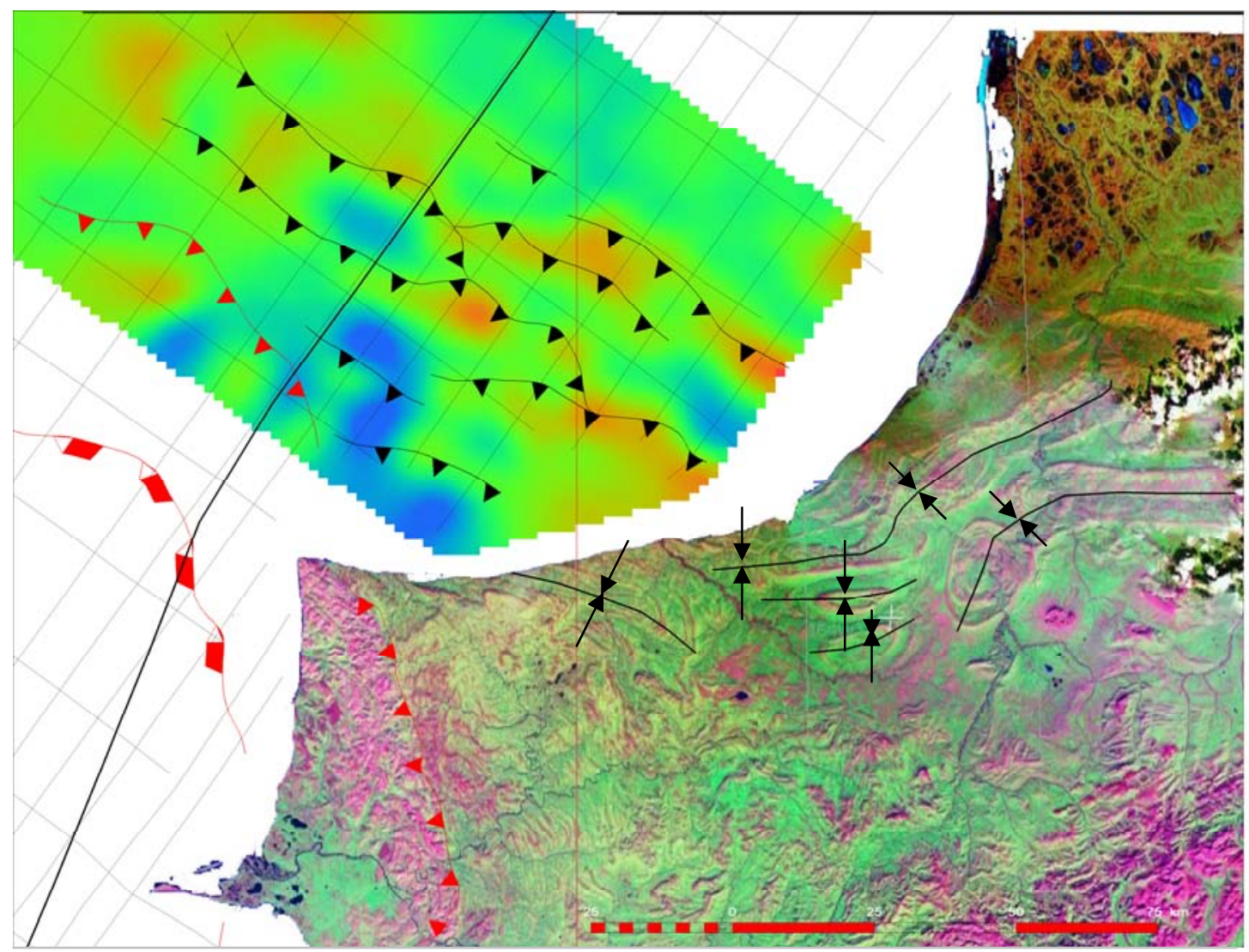

Figure 31: Landsat Image combined with the structure map to the Brookian 1 horizon. The heavy black line is the USGS-Stanford line and the light black are the Western Geco lines. The black thrusts are the Brookian thrusts with the arrows on the hanging wall. The red line shows the Herald Thrust with the arrows on the hanging wall. The satellite image is from Landsat Geocover 1990 and was interpreted with the help of J. Toro. 


\begin{tabular}{|l|l|l|l|l|}
\hline \multirow{2}{*}{ LINE } & HORIZON & $\begin{array}{c}\text { PRESENT } \\
\text { LENGTH (Km) }\end{array}$ & $\begin{array}{l}\text { RECONSTRUCTED } \\
\text { LENGTH (Km) }\end{array}$ & $\begin{array}{c}\text { PERCENT } \\
\text { SHORTENING }\end{array}$ \\
\hline \multirow{2}{*}{104} & B1 & 17.85 & 18.15 & 1.6 \\
\cline { 2 - 5 } & B2 & Not Clearly Visible & Not Clearly Visible & - \\
\hline \multirow{2}{*}{106} & B1 & 26.78 & 27.75 & 3.5 \\
\cline { 2 - 5 } & B2 & Not Clearly Visible & Not Clearly Visible & - \\
\hline \multirow{2}{*}{108} & B1 & 35.1 & 39.00 & 10.0 \\
\cline { 2 - 5 } & B2 & 38.25 & 42.75 & 10.5 \\
\hline \multirow{2}{*}{112} & B1 & 45.75 & 51.23 & 10.7 \\
\cline { 2 - 5 } & B2 & 48.15 & 52.5 & 8.3 \\
\hline \multirow{2}{*}{114} & B1 & 50.48 & 57.75 & 12.6 \\
\cline { 2 - 5 } & B2 & 52.73 & 60.75 & 13.2 \\
\hline \multirow{2}{*}{116} & B1 & 56.25 & 68.4 & 17.8 \\
\cline { 2 - 5 } & B2 & 59.63 & 72.75 & 18.0 \\
\hline \multirow{2}{*}{118} & B1 & 71.25 & 82.88 & 14.0 \\
\cline { 2 - 5 } & B2 & 71.63 & 84.53 & 15.3 \\
\hline \multirow{2}{*}{124} & B1 & 64.88 & 71.25 & 9.4 \\
\cline { 2 - 5 } & B2 & 64.88 & 74.78 & 13.2 \\
\hline \multirow{2}{*}{126} & B1 & 70.5 & 74.85 & 5.8 \\
\cline { 2 - 5 } & B2 & 71.4 & 77.63 & 8.0 \\
\hline \multirow{2}{*}{128} & B1 & 90.75 & 91.65 & 1.0 \\
\cline { 2 - 5 } & B2 & 91.5 & 93.15 & 6.3 \\
\hline \multirow{2}{*}{130} & B1 & 85.95 & 91.73 & 4.1 \\
\cline { 2 - 5 } & B2 & 88.13 & 91.88 & 6.3 \\
\hline \multirow{2}{*}{132} & B1 & 75 & 81.38 & \\
\cline { 2 - 5 } & B2 & 76.28 & & 4.3 \\
\hline
\end{tabular}

Table 1A: Percent shortening due to all faults except the main Herald Thrust Fault. On seismic lines 104 and 106, Brookian 2 was very difficult to trace and was not included.

\begin{tabular}{|l|l|l|l|}
\hline \multicolumn{1}{|c|}{ LINE } & $\begin{array}{c}\text { PRESENT } \\
\text { LENGTH (KM) }\end{array}$ & $\begin{array}{c}\text { RECONSTRUCTED } \\
\text { LENGTH (KM) }\end{array}$ & $\begin{array}{c}\text { PERCENT } \\
\text { SHORTENING }\end{array}$ \\
\hline 104 & 18.0 & 28.50 & 37 \\
\hline 106 & 25.13 & 44.25 & 43 \\
\hline 108 & 31.88 & 50.25 & 37 \\
\hline 112 & 21.75 & 27.38 & 21 \\
\hline 114 & 21.37 & 34.88 & 39 \\
\hline 116 & 22.5 & 35.63 & 37 \\
\hline
\end{tabular}

Table 1B: Percent shortening due to the Herald Thrust. 


\section{Chapter 5: Gravity and Magnetic Data}

\section{1: Introduction}

In addition to seismic and well data, gravity and magnetic data provided additional geophysical constraints on the nature of the Herald Arch. The regional gravity and magnetic fields in the area proved additional information about the upper mantle and crustal structures beneath the area. These two data sources were helpful in providing a broader view of the study area. These data were also used to create profiles to be compared to seismic data and to calculate maximum possible depths to anomalies. Used in conjunction with the seismic data, it was determined that the gravity data show strong correlations to features at and above basement rock depth. Magnetic anomalies show a stronger correlation to the deeper Moho and the Herald thrust.

Correlations related to the depth of the Moho are not as well constrained as those for the depth to Basement since only the two USGS-Stanford lines are resolvable at those depths. The Moho contours were both computer and hand generated and contain data only along the two deep crustal lines. Shown in this study is a combination of computer and human interpretations. The basement contours have many more control points. These contours were computer generated but are much more accurate due to the greater number of data points.

\subsection{1: Gravity}

Gravity data for this project is a satellite-derived free-air gravity survey that was acquired over the world's oceans (Smith and Sandwell, 1997). These data have been 
preprocessed with a low-pass filter with 0.5 gain at a wavelength of $20 \mathrm{~km}$ (Klemperer et al., 2002). Large gravity lows can be seen in the vicinity of the Hope Basin to the south of the Herald Arch and in the Colville Basin (box A, figure 32) to the north east of the Herald Arch. This coincides well with the large basins that are interpreted from seismic data. There are also two bands of gravity highs: one parallels the southern edge of the Herald Arch in a southeast-northwest direction before bending towards the north (box B, figure 32), the other runs parallel to the arch but lies to the south, near the edge of the Hope Basin (box C, Figure 32).

When depth to Moho contours are combined with the gravity data, there is no strong correlation with a gravity high in the vicinity of the Herald Arch corresponding to the thinning of the crust (figure 33). There is however, a stronger correlation between the gravity data and the depth to basement (figure 34). The steep basement rise near the Herald Arch matches the gravity high just off the northern point of the Lisburne Peninsula. The basement contours change from a northwest trend to a more northern trend as the edge of the Herald Thrust approaches. The gravity high also bends to the north, closely following the contours. The gravity low near the Colville Basin matches the deepest parts of the basement. In the area to the southwest of the Herald Arch, the basement is roughly a constant depth, ranging from 0 to 1.2 seconds deep. In this same area, there is a gravity low just to the southwest of the of the Herald Arch before changing to a high approaching the Hope Basin before again dropping to the expected gravity low. 


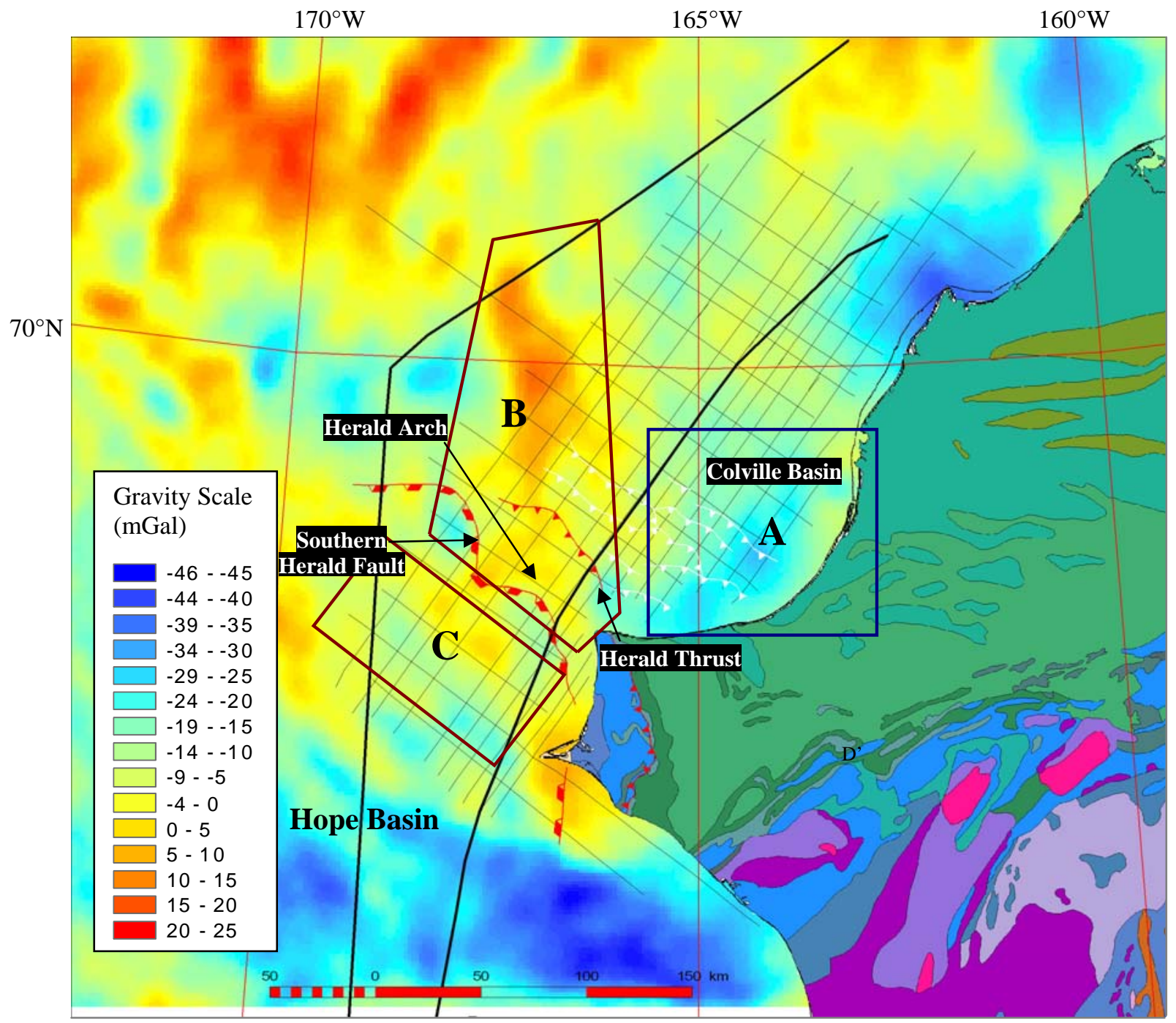

Figure 32: Gravity map with overlays of the interpreted Herald Thrust, Southern Herald Fault, and Brookian Thrusts in white along with the Western Geco and Stanford seismic lines. Box A encloses a gravity low, areas with less dense material, corresponding to the Hanna Trough and Colville Basin. Boxes B and C enclose gravity highs, areas with denser material. 


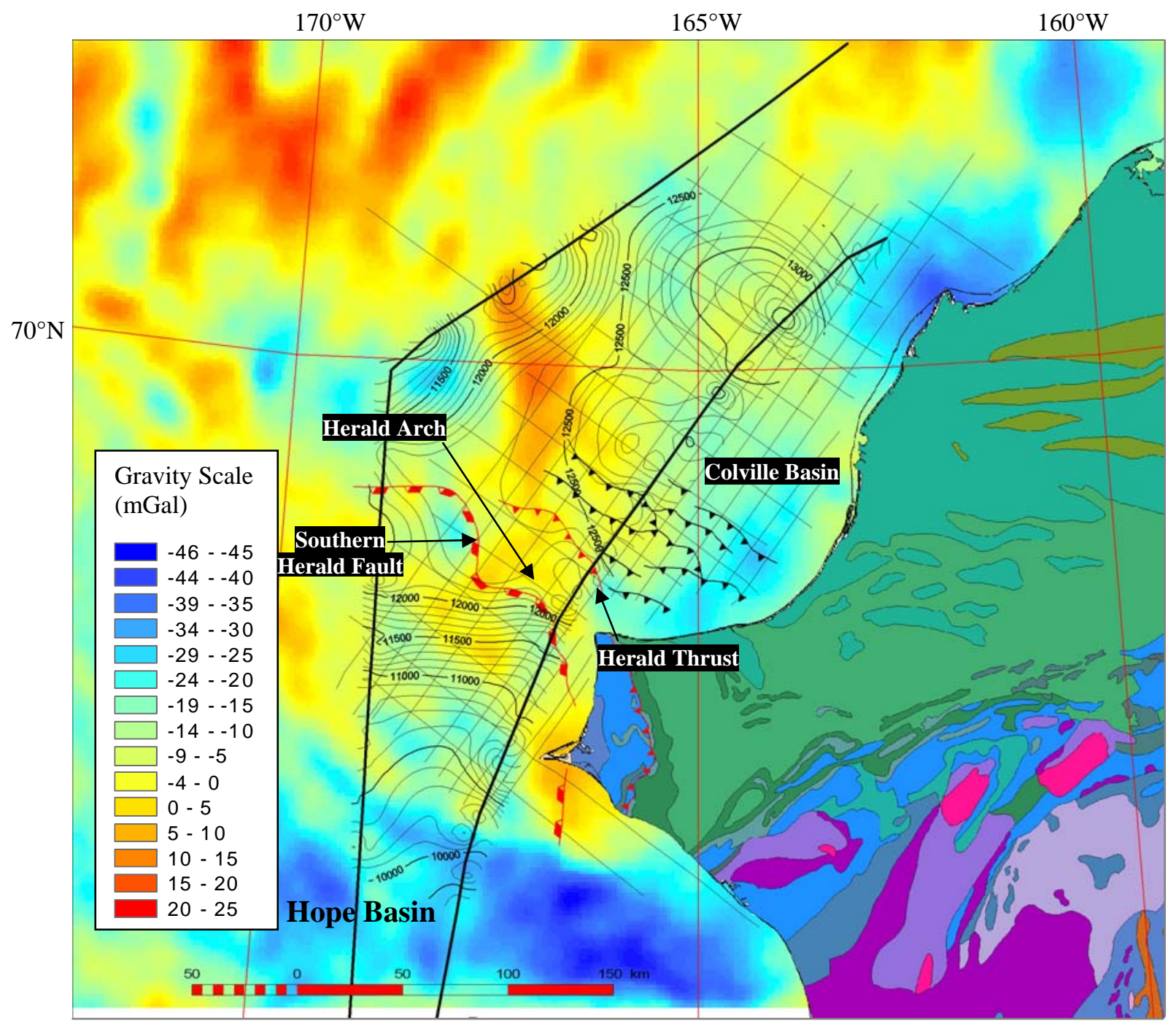

Figure 33: Gravity map with overlays of the two-way time depth to Moho in milliseconds. Warm colors are gravity highs, where there is dense material and the cool colors show areas with less dense material. The Moho does not appear to correlate will the gravity anomalies. 


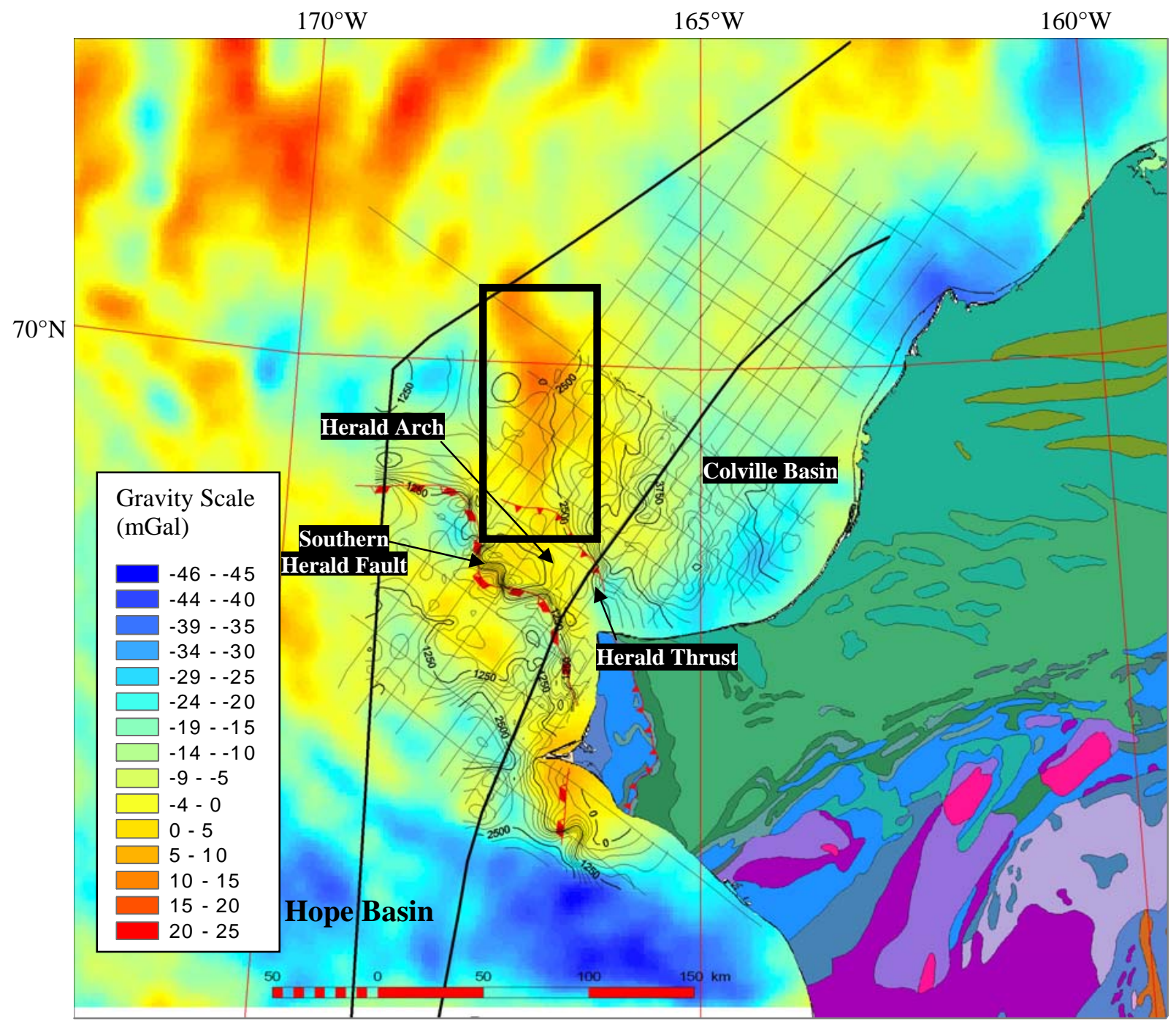

Figure 34: Gravity map with overlays of the two-way time depth to basement in milliseconds. Warm colors are gravity highs, where there is dense material and cool colors show areas with less dense material. The southern Herald Fault parallels a gravity high indicating the Herald Thrust, and its denser basement rock, is influencing the gravity data. The northern trend of the gravity high also closely parallels a basement high (box A). 


\subsection{2: Magnetic}

The magnetic data (Macnab et al., 1995 and Verhoef et al., 1996) for the study area contains short and medium-wavelength (less than $400 \mathrm{~km}$ ) magnetic anomalies over the Arctic and adjacent land areas. Numerous datasets were "merged to develop a digital data base of coherent magnetic observations suitable for quantitative tectonic interpretations" (Klemperer et al., 2002). The most prominent feature is the "L-shaped" magnetic high which starts over the Herald Thrust and then bends abruptly to the north (figure 35 box A). This magnetic high closely follows the trend of the gravity high. The northerly trend is flanked by magnetic lows on the west and east sides with the east side low within the Colville Basin area but the western low area lies in an area not covered extensively enough by the seismic grid to determine the structural features.

Magnetic data combined with the Moho contours shows a slight correlation in the Herald Arch area (figure 36). Here, there is a magnetic high as the Moho becomes changes from $37 \mathrm{~km}$ to about $30 \mathrm{~km}$ deep. A better correlation with the Moho can be interpreted with the northern part of the L-shaped magnetic high and the 12.5 seconds (36 $\mathrm{km}$ ) deep Moho. This is still somewhat suspect because of the lack of data points between the two Stanford-USGS deep crustal lines. When the depth to basement is combined with the gravity data (figure 37) additional correlations are evident. In figure 35, box A, where rapid rise in basement depth from about 2 to 1.2 seconds occurs, the bend in the magnetic data also occurs suggesting a relationship between the magnetic high and Herald Thrust. 


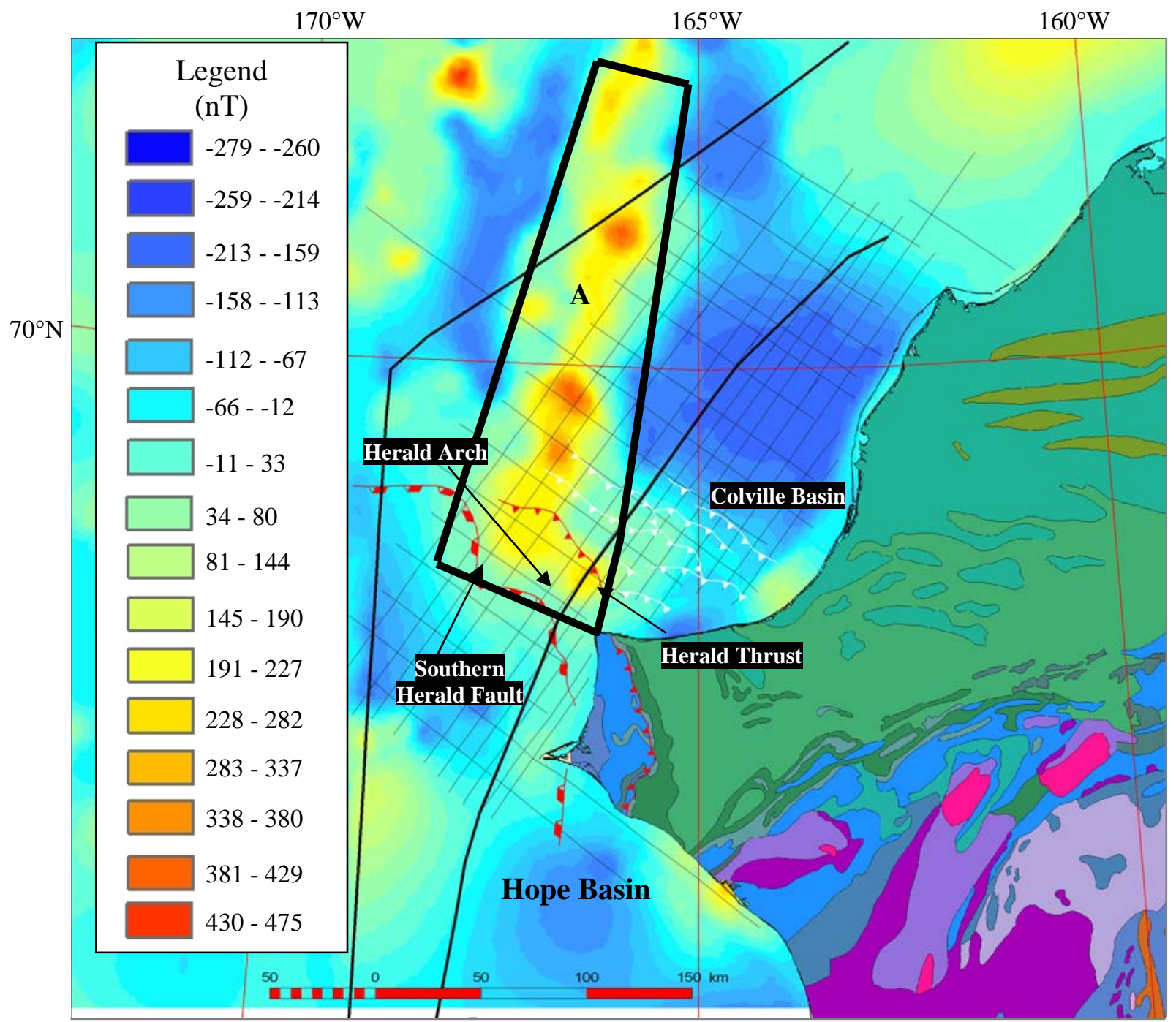

Figure 35: Magnetic data with overlays of the interpreted Herald Faults (red) and the Brookian Thrusts in white. Box A encloses the main magnetic high within the study area. 


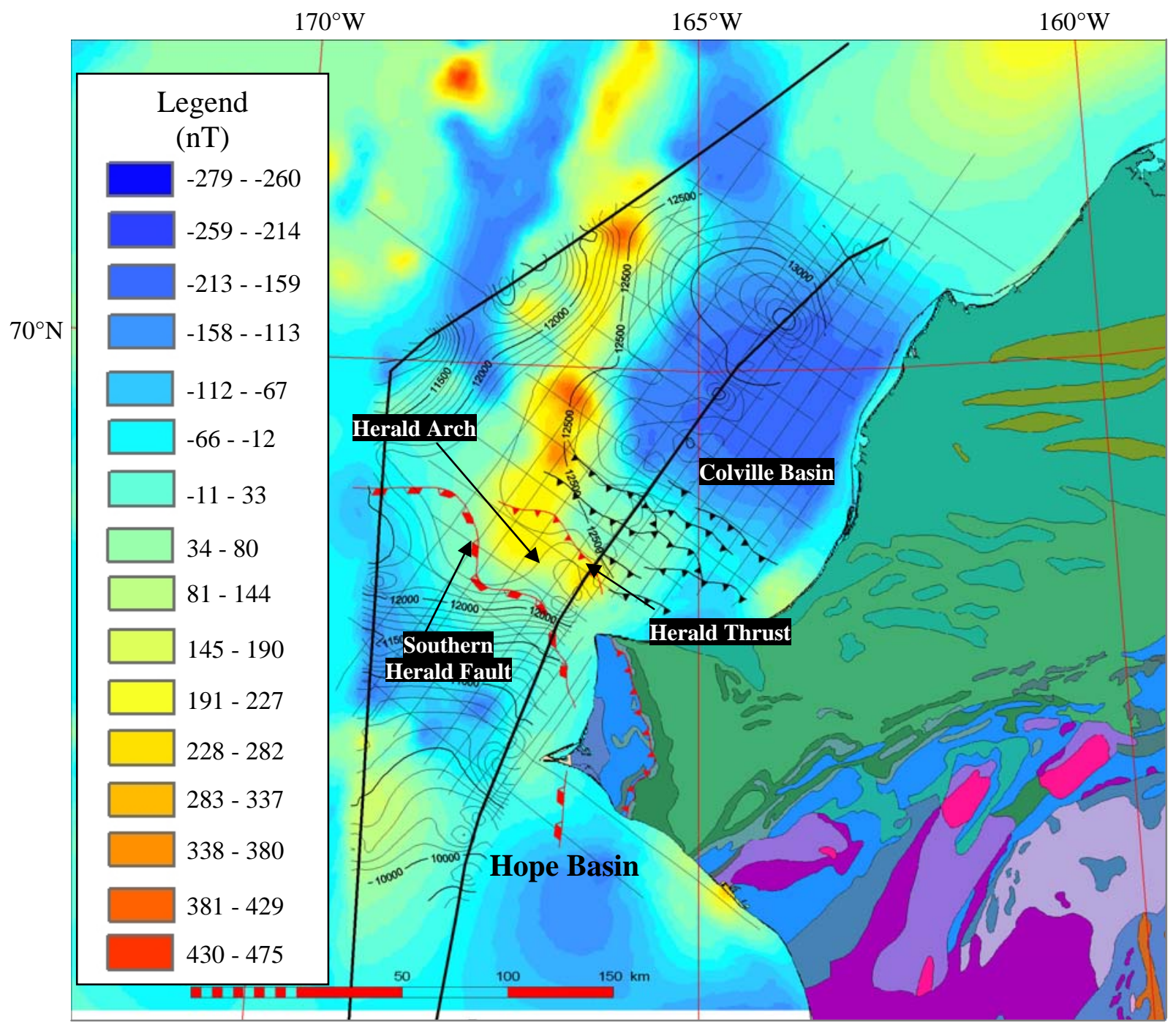

Figure 36: Magnetic data with overlays of the two-way time depth to Moho in milliseconds. Warm colors represent a strong magnetic area while cool colors represent weak magnetics. Heavy black lines are the USGS-Stanford seismic ship track along where the data for the Moho was collected. The 12.5 second computer interpreted contour line parallels the magnetic high but does not provide a convincing match. 


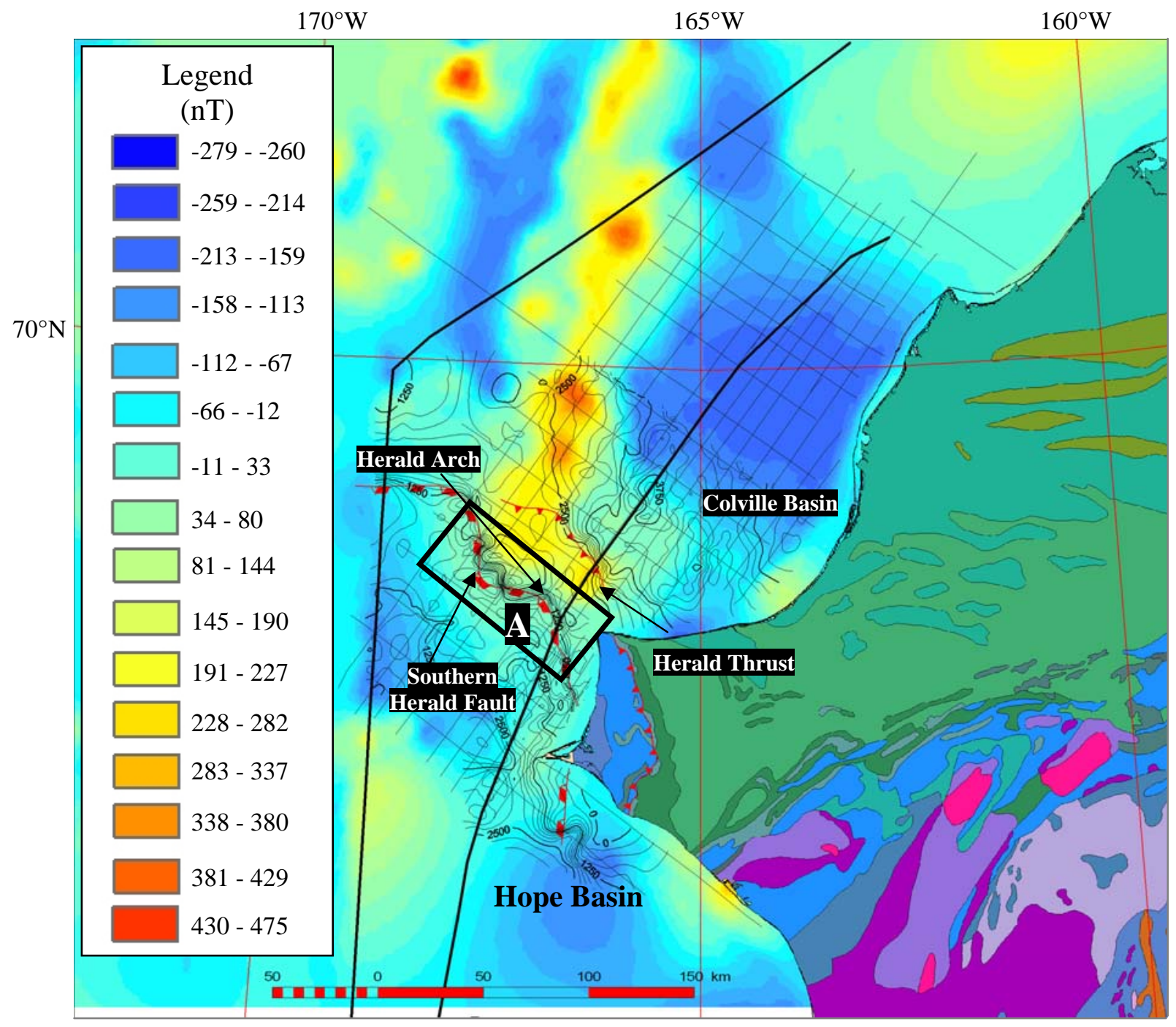

Figure 37: Gravity map with the depth to basement contours. The depths are in milliseconds for the contour data with the warm colors showing magnetic highs and the cool colors showing magnetic lows. Box A shows the close relationship between the Southern Herald Fault, Herald Arch and the main magnetic high. The basement contours to the north also parallel the magnetic high to the north indicating a possible relationship between the basement at about 2 seconds and the magnetic data. 


\section{2: Gravity and Magnetic Profiles}

Nine gravity and nine magnetic profiles across the study area were created to compare the highs and lows of the survey data to seismic data. Using ArcView software, gravity (mGals) and magnetic (nT) profiles were created. The same ship tracks for deep crustal lines 5181 and 5187 and shallower lines 104, 106, 107, 108, 111, 112, and 115 were followed for both the gravity and magnetic data profiles. The profiles show the changes of high and low as well as positive and negative anomalies for the gravity and magnetic data respectively. When these are paired with the seismic data, it is easier to see correlations with changes in depth to the formations. Figures 38 and 43 show the locations of the profiles for the gravity and magnetic data.

The peaks (figures 39-42 and 44-47) corresponding to the area near the Herald Arch were used to calculate the maximum depth for the object causing the anomaly. In addition to the Herald Arch anomalies, other spikes and their corresponding maximum depths were calculated using approximation techniques of Burger (1992). Maximum depths for most of the anomalies were located in the basement rock, not within the sedimentary section. The peaks are identified in the figures by the black arrows and their corresponding half-maximums are identified by the red, horizontal arrows (figures 39-42 and 44-47). The maximum depth to the anomalies is identified by a white circle beneath the peak arrow unless the maximum calculated depth was beyond the reach of the seismic data, in which case a white arrow pointing down identifies the location. The calculations for the gravity and magnetic anomalies are slightly different and will be explained in their respective sections. 


\subsection{1: Gravity Profiles}

Figures 39, 40 and 41 show lines: USGS Stanford deep-crustal 5181, WGS 108 and WGS 104 respectively, along with the coincident gravity profiles to show the changes of the gravity values and geometry of the Herald Arch from the southeast to the northwest. Figure 42 shows line WGS 111 going from southwest to northeast. The first profile, USGS Stanford deep crustal line 5181 (figure 39), includes the Moho as well as the remaining shallower horizons. As the Moho rises from right to left (north to south) on the seismic data, no general corresponding trend can be seen on the profile. When the basement is compared to the gravity profile, a correlation becomes more evident.

Starting in the Hope Basin to the south, the gravity lows match the basement lows until reaching the edge of the basin (figures 39, 40 and 41). As the basement rises, the gravity anomaly shows a progressively increasing high until reaching the Herald Arch where it attains a maximum. At the Herald Arch, the gravity profile levels off but then begins to change to a low moving towards the Colville Basin. The exception to this is on line 104 where the Herald Arch shows a gravity low increasing rapidly until just beyond the arch (figure 41). It remains high until, like the previous lines, it drops again upon reaching the Colville Basin. There is a second spike on the gravity data just before the deepest parts of the Colville Basin in the northeast. This spike is most prominent in the lines to the southeast (figures 39 and 40) but in this study could not be found on line 104 (figure 41). Finally, the gravity data follows the basement by becoming a low within the Colville Basin. Figure 42 shows the cross line WGS 111 and shows similar features as the northwest trending profiles. The Colville Basin to the south creates a low in the 
basement and gravity values while the area of the Herald Arch maintains a gravity and basement high.

The curves for most of the lines appear to show two anomalies, a deeper one with broad curve with a shallower anomaly superimposed creating a series of more prominent peaks. Depths to the anomalies were estimated using the simple model of the halfmaximum technique (Burger, 1992). This assumes the basic shapes of horizontal cylinders and spheres and that the maximum gravity will be located over the center of the shape. From the curve, the value where the gravity drops to half its peak value is the half-maximum. The horizontal distance between the maximum and half-maximum is proportional, $1 / 1$ for a cylinder and 1/0.77 for spheres, to the depth of the anomaly. Table 2 shows calculations for the profiles shown in figures 39, 40, 41 and additional profiles not shown.

Figure 39 shows a gravity high corresponding to the Hanna Trough, a basin filled by sedimentary rock. Usually, basins show gravity lows because sedimentary fill is less dense than igneous and metamorphic basement rock. This gravity high could be a dense mafic mass that lies within the crust which could be indicated by a magnetic anomaly. However, figure 44 shows no magnetic anomaly corresponding to the Hanna Trough. If the mafic mass remained within the crust and below $20 \mathrm{~km}$, keeping it above the Curie isotherm and thus magnetically neutral, it would not appear as a magnetic anomaly (Sherwood et al., 2002). I have calculated an approximate maximum depth for the anomaly of $12 \mathrm{~km}$ which lies at the base of the Hanna Trough. However, the possible mafic mass is not resolvable on the seismic data at this depth. 


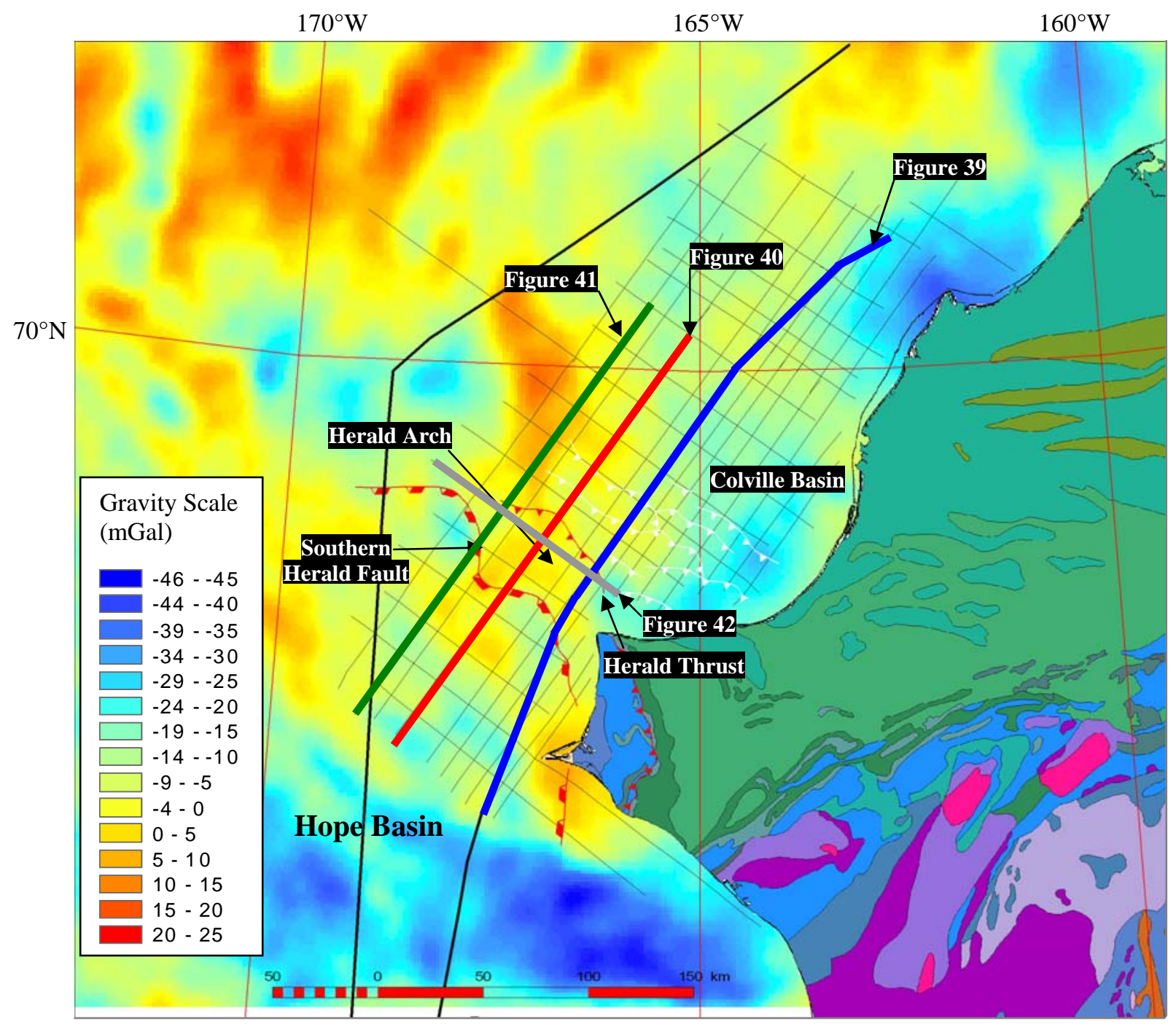

Figure 38: Gravity map showing the locations of the seismic profiles in figures 39-42. Blue line is the profile location for the deep crustal USGS-Stanford line 5181 in figure 39. Red line is the profile location for WGS 108 show in figure 40. Green line shows the profile location for WGS 104 shown in figure 41. Grey line shows the profile location for WGS 111 shown in figure 42. 
Depth

(km)

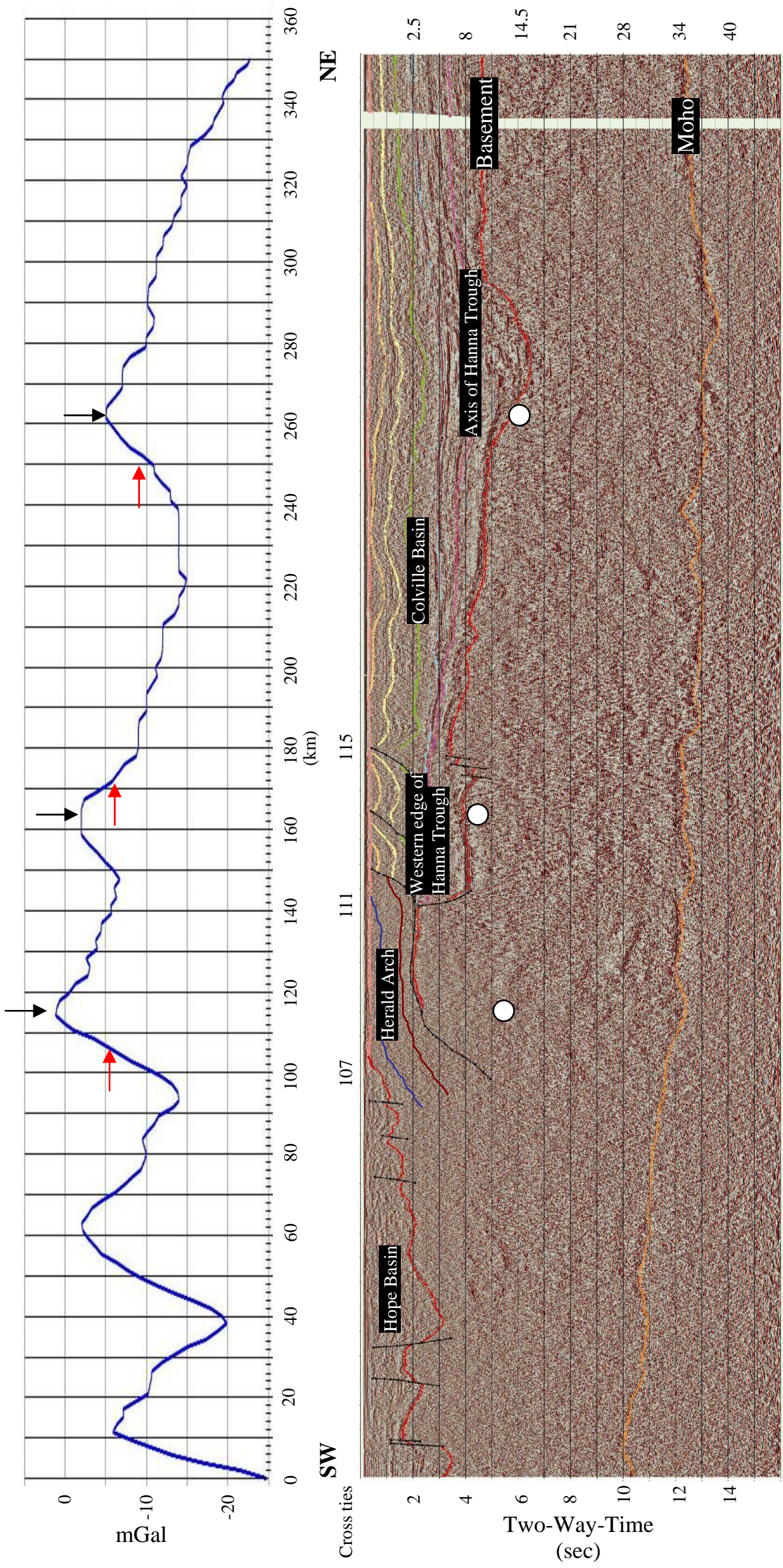

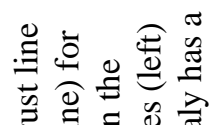

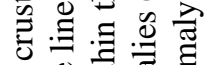

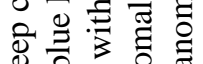
을 밈 政

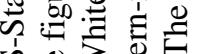
ज活 3 ஸ. $\dot{3}$

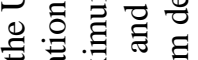

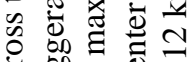
च 월 吾

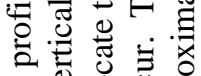

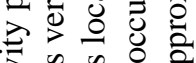

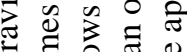
क. 少元矛䒕 事 的苛导就

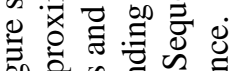

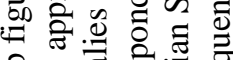

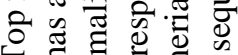

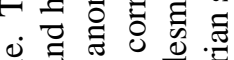

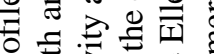

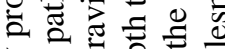

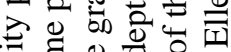

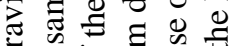

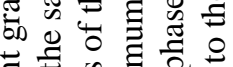

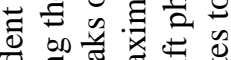
记 त

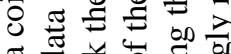
त 중

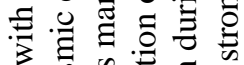

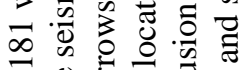

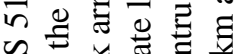

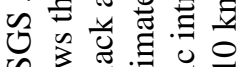

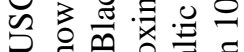

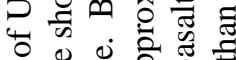
용 命 . 范

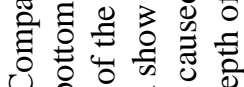

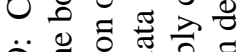

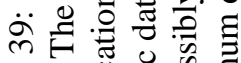

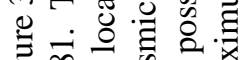

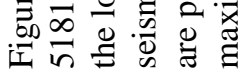
(sec) 


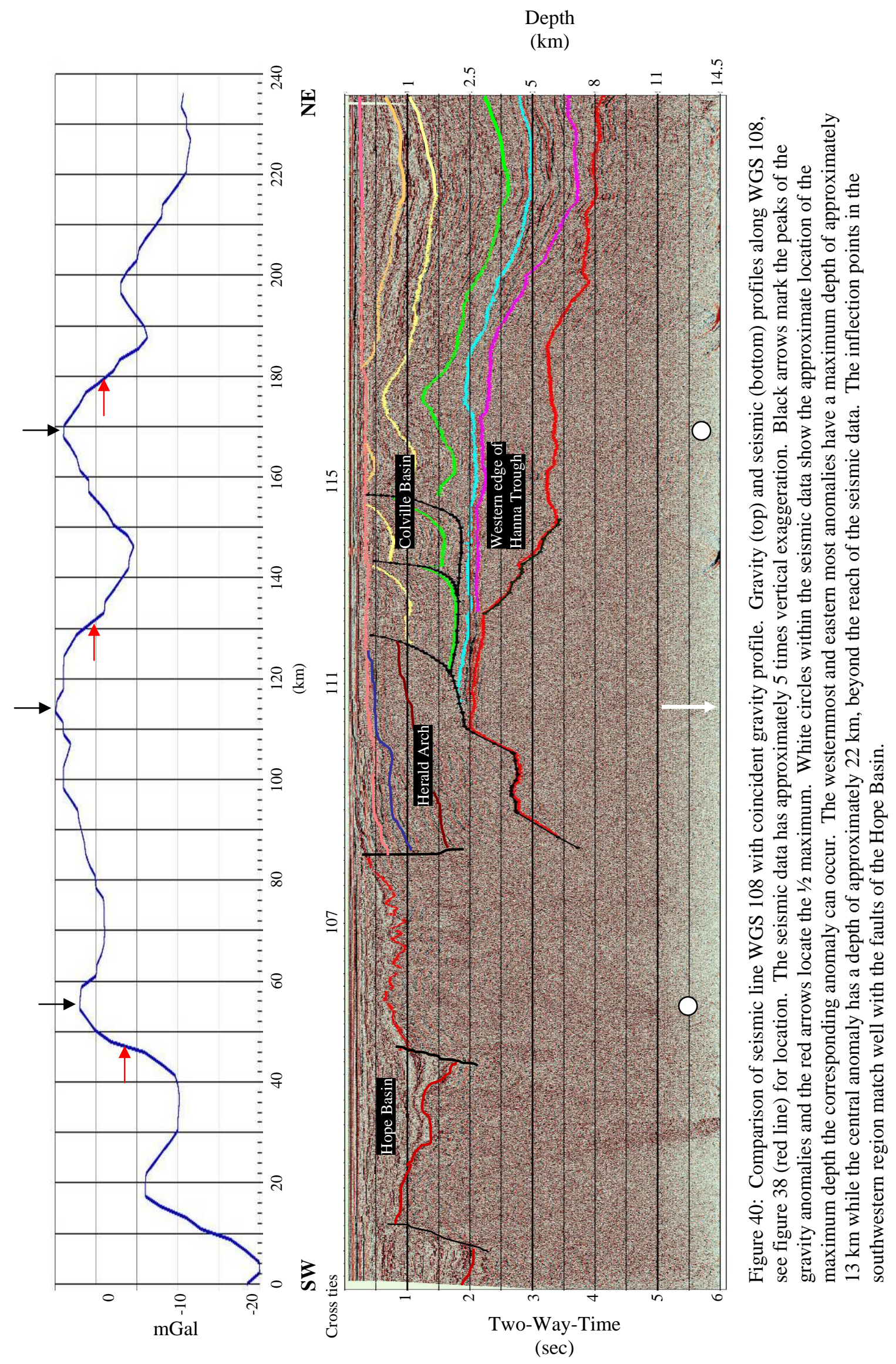




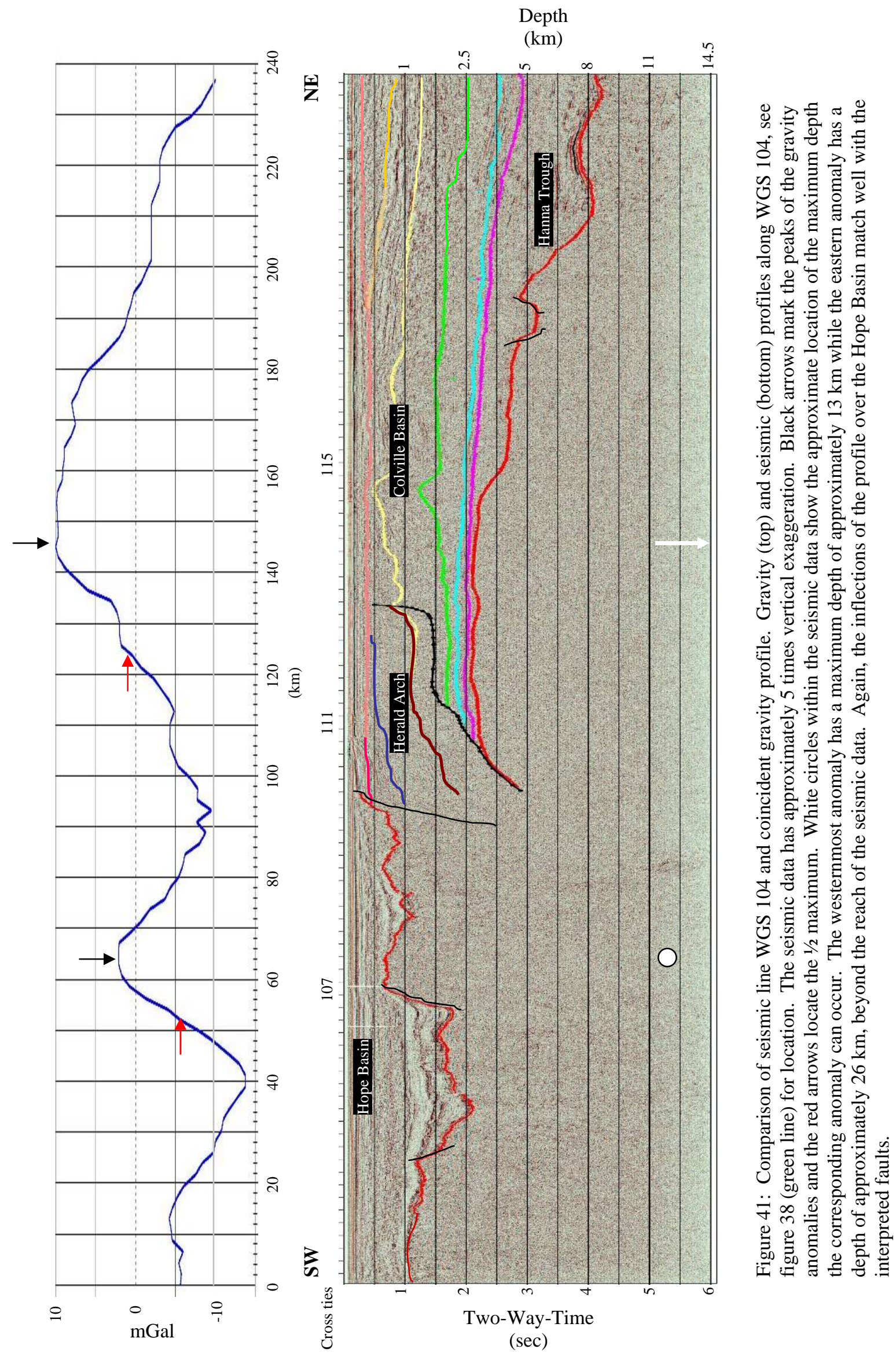




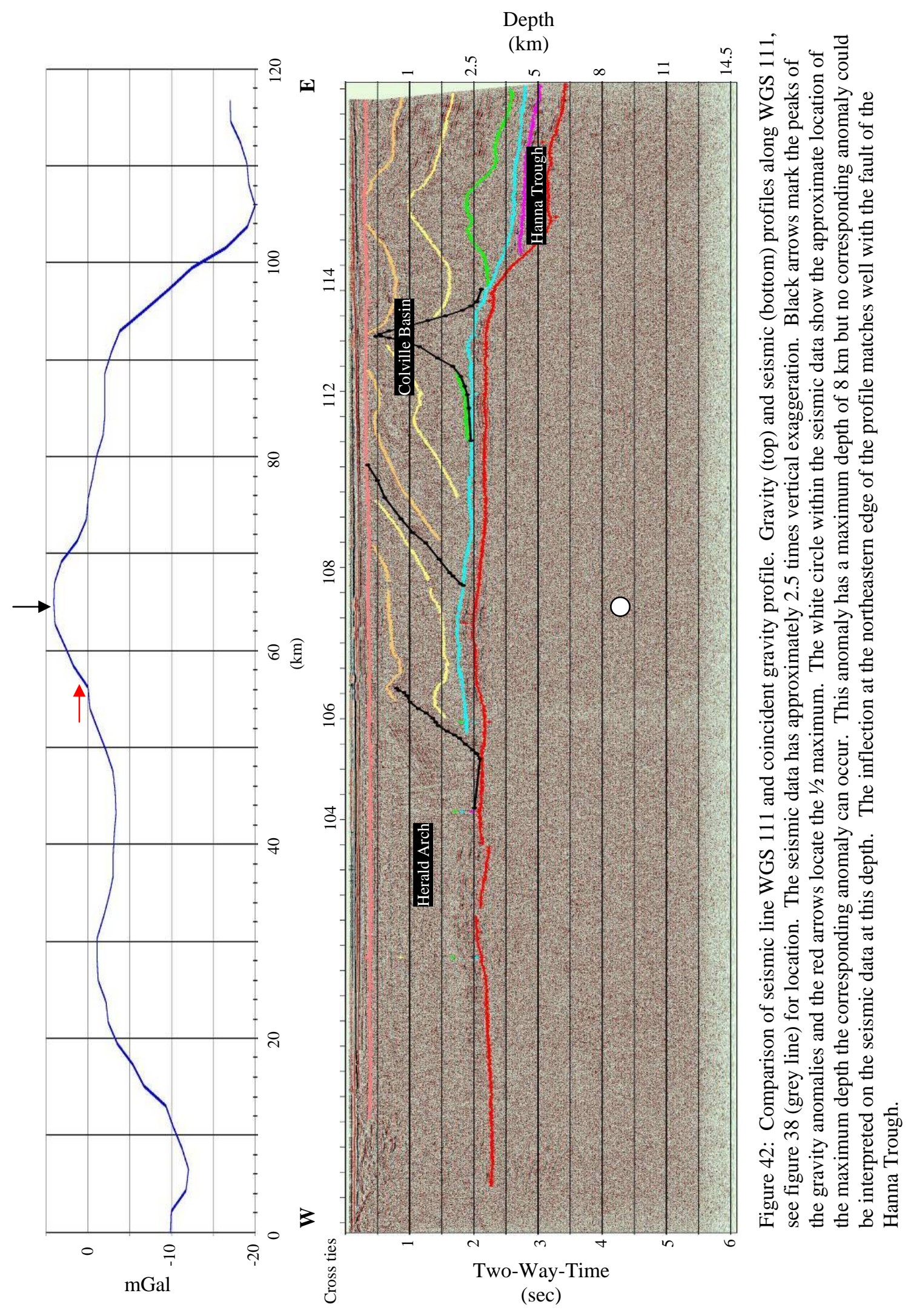




\begin{tabular}{|c|c|c|c|}
\hline LINE & $\begin{array}{c}\text { DISTANCE } \\
\text { BETWEEN PEAK } \\
\text { AND 1/2 MAXIMUM } \\
(\text { Km) }\end{array}$ & $\begin{array}{c}\text { DEPTH TO } \\
\text { ANOMALY } \\
\text { (CYLINDER) (Km) }\end{array}$ & $\begin{array}{c}\text { DEPTH TO } \\
\text { ANOMALY } \\
\text { (SPHERE) (Km) }\end{array}$ \\
\hline 5181 & 10 & $10(5 \mathrm{sec})$ & $13(5.5 \mathrm{sec})$ \\
\hline 112 & 10 & $10(5 \mathrm{sec})$ & $13(5.5 \mathrm{sec})$ \\
\hline 108 & $16^{*}$ & $16(7 \mathrm{sec})$ & $21(8 \mathrm{sec})$ \\
\hline 104 & $24^{*}$ & $24(9 \mathrm{sec})$ & $31(10.5 \mathrm{sec})$ \\
\hline 5187 & 13 & $13(5.5)$ & $17(7.2 \mathrm{sec})$ \\
\hline
\end{tabular}

Table 2: Estimated maximum depths to anomalies causing the gravity spikes in the vicinity of the Herald Arch.

* Profile is very broad causing the $1 \frac{1}{2}$ maximum to be farther from the peak, this suggest a wider anomaly. 


\subsection{2: Magnetic Profiles}

Magnetic profiles were created over the same ship tracks as the gravity profiles.

Figures 44, 45, 46 and 47 are along the same seismic profiles as those for the gravity data (seismic lines 5181, 108, 104 and 111 respectively) and show the magnetic anomaly profile compared with the coincident seismic data. The first profile (figure 44) shows a nearly neutral magnetic value before reaching the Herald Arch where there is a sudden rise in the magnetic values. The values return to near zero but then drop off approaching the deeper part of the Colville Basin (figure 44). The remaining profiles (figures 45, 46 and 47) show a similar neutral magnetic value until the region of the Herald Arch is reached and is accompanied by a magnetic peak. The magnetic peak becomes much broader and increases in value moving to the northeast, where the magnetic maps show a change in trend from northwest to north. The Colville Basin accompanies the magnetic low, as the basement drops to below 4-5 seconds on the seismic data.

The maximum depth to the anomaly causing the spike on line 5181 was estimated using a simple model assuming the anomaly was a cylinder or sphere similar to the gravity profiles (Burger, 1992). Calculations for the profiles shown, 5181, 108 and 104 along with profiles not shown, 112 and 5187, were done using the half-maximum technique (Burger, 1992). Table 2 shows the line and the estimated maximum depth assuming the anomaly is a cylinder or sphere. The horizontal distance between the maximum and half-maximum is proportional, $1 / 0.495$ for a cylinder and $1 / 0.5$ for spheres, to the depth of the anomaly when both are assumed to be vertically polarized.

The magnetic peak can not be caused by an anomaly more then 9.5 seconds (26 km) below the Herald Arch. However, the relationship between the strike of the 
magnetic anomaly in map view and the depth to basement marking the edge of the Herald Arch (figure 37) suggests the two features are related. A shallower anomaly, just below the curved reflector marking the base of the Herald Arch, could be the cause of the magnetic anomaly. The Herald Thrust could have brought up mafic material causing the anomaly or perhaps a rifting event, after the Ellesmerian, caused a mafic intrusion and the anomaly. 


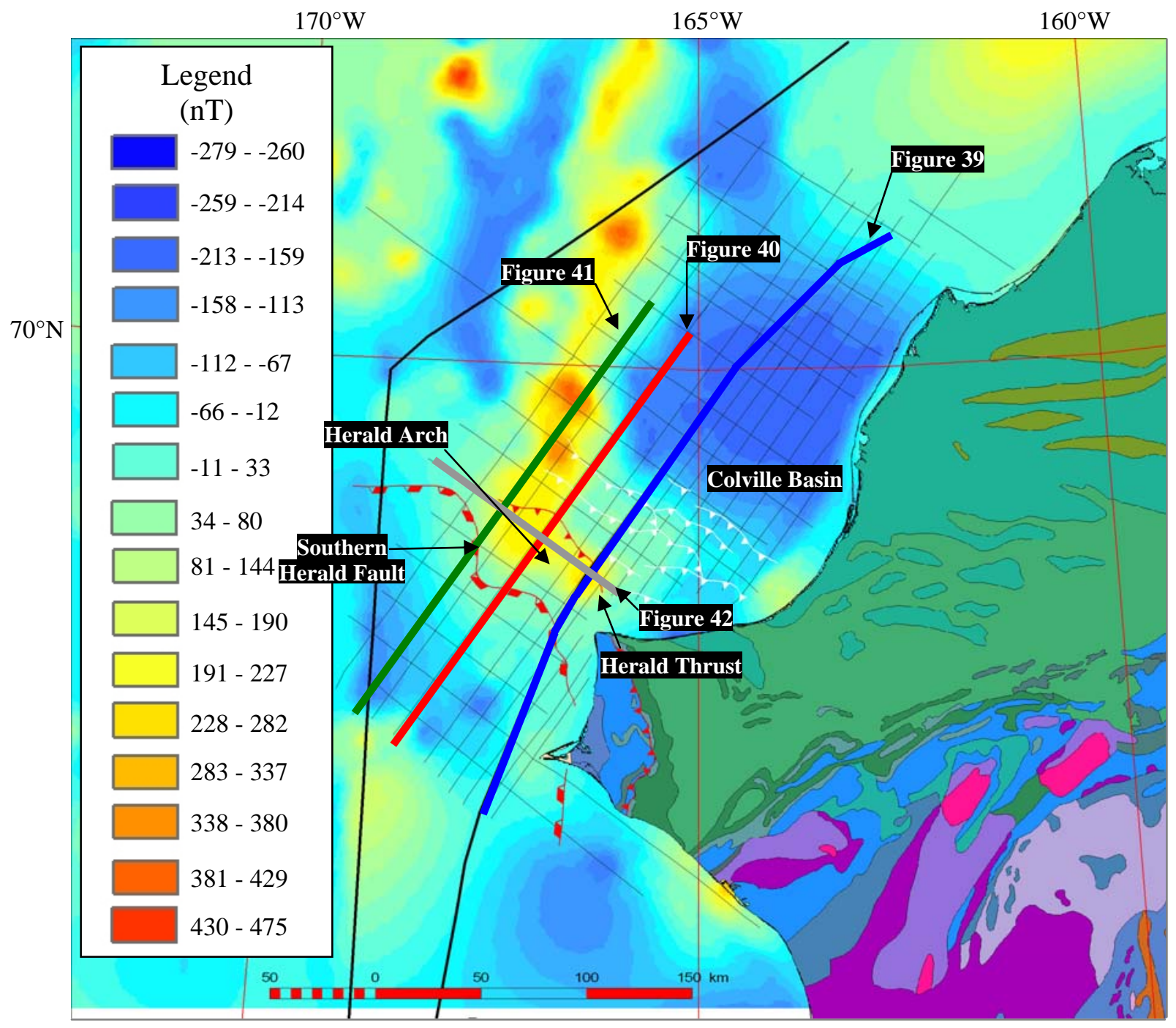

Figure 43: Magnetic map showing the locations of the seismic profiles in figures 44-47. The blue line is the profile location for the deep crustal USGS-Stanford line 5181 in figure 44 . The red line is the profile location for WGS 108 show in figure 45. The green line shows the profile location for WGS 104 shown in figure 46. The grey line shows the profile location for WGS 111 shown in figure 47. 


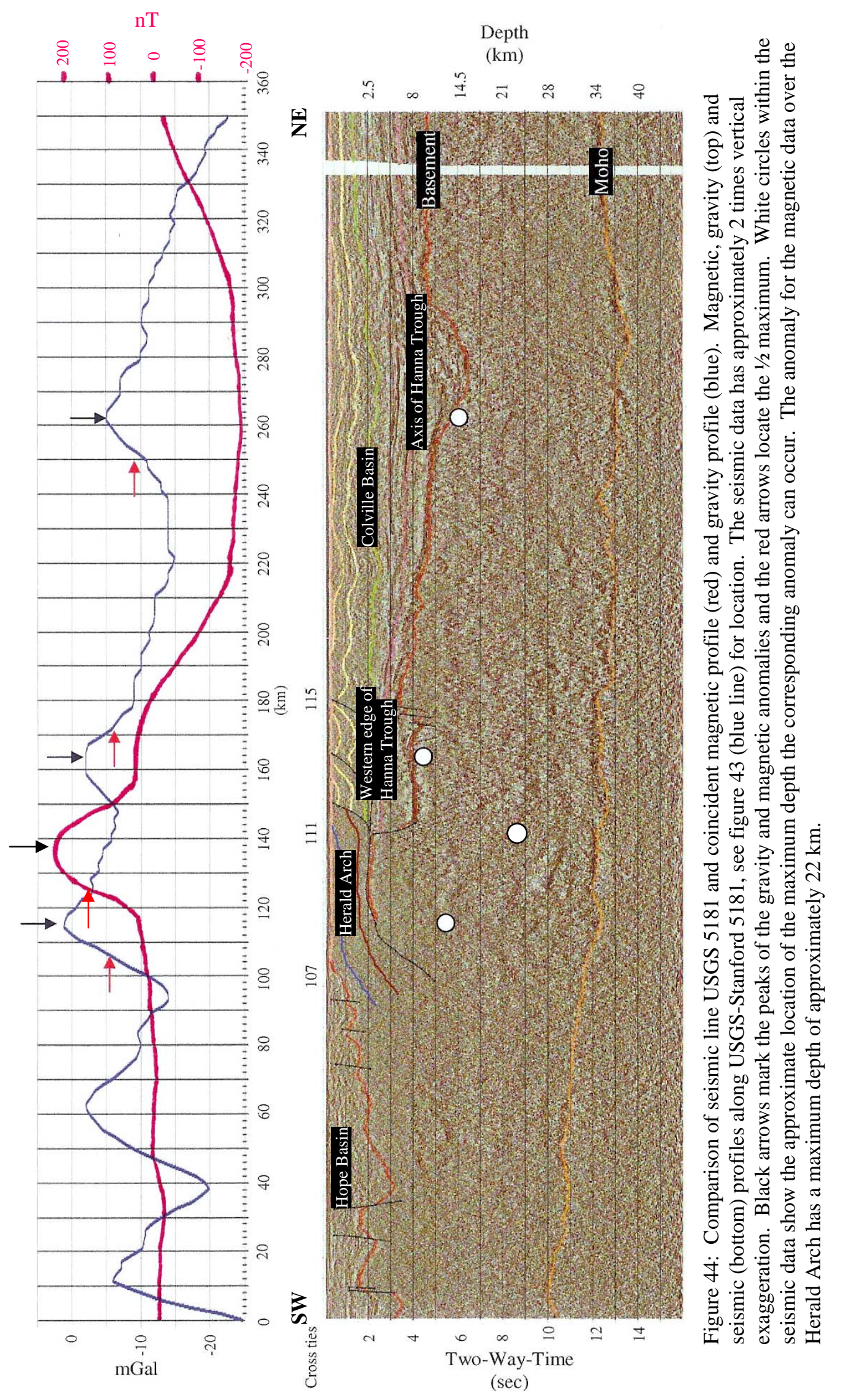




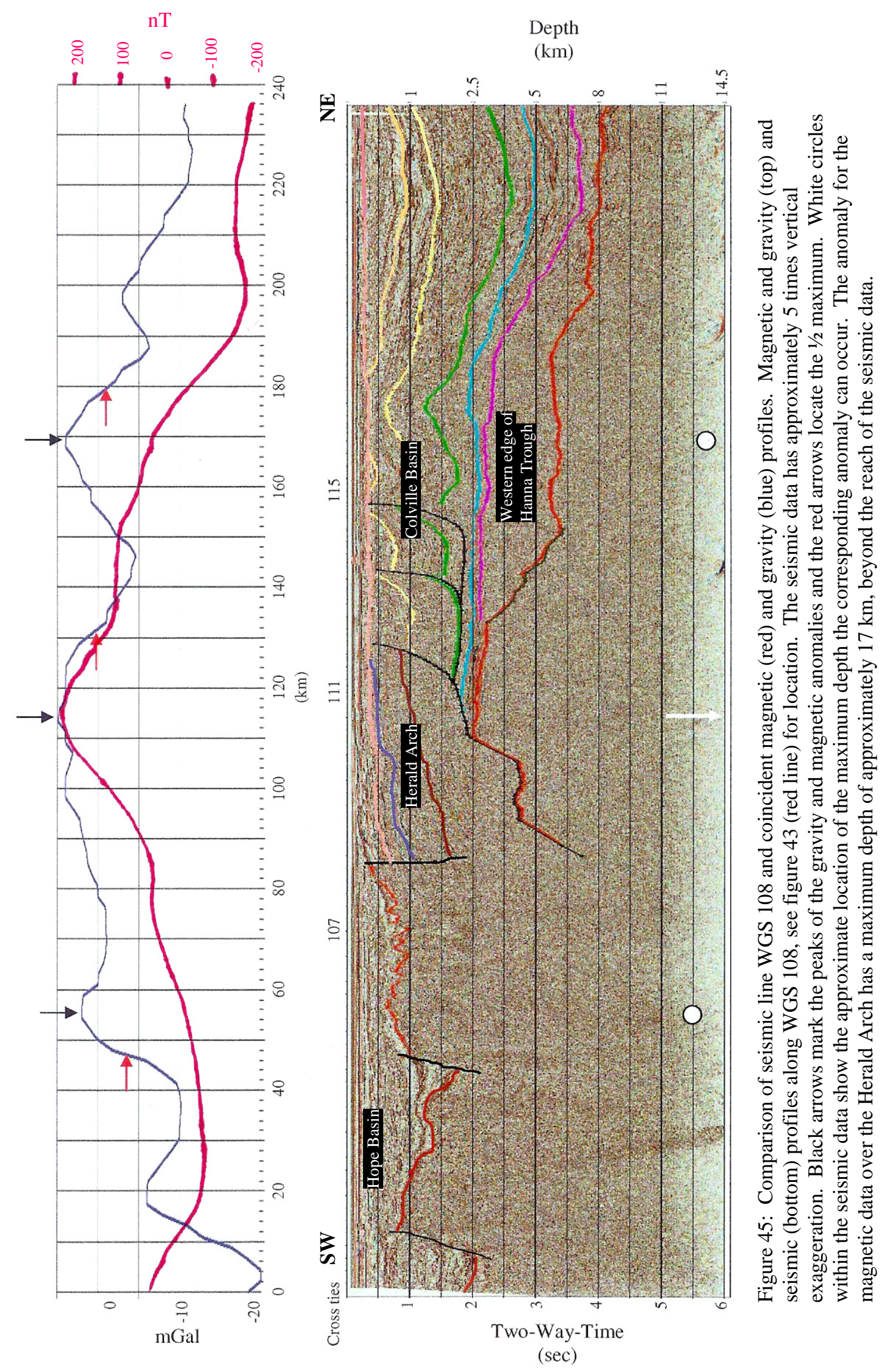




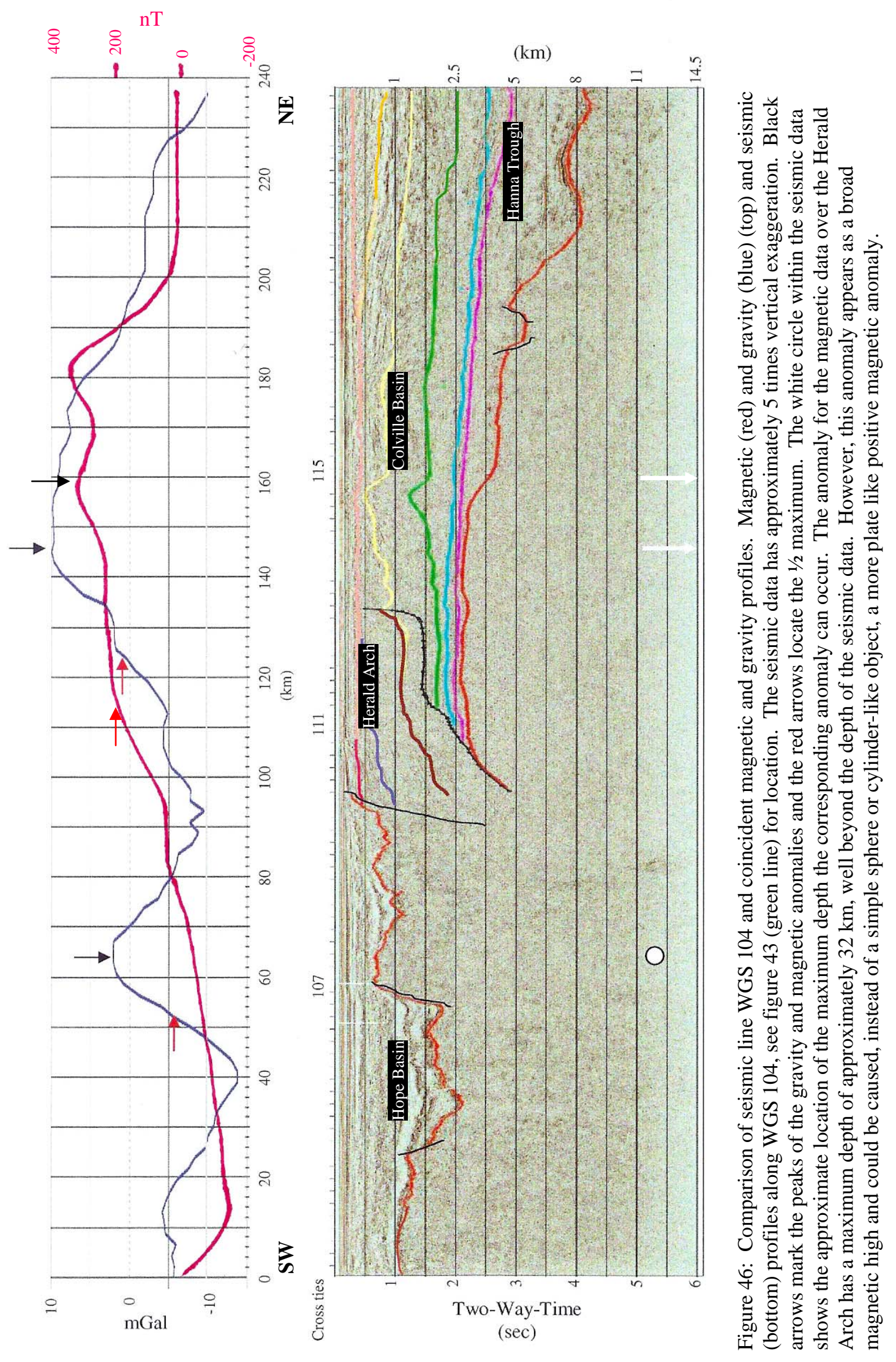




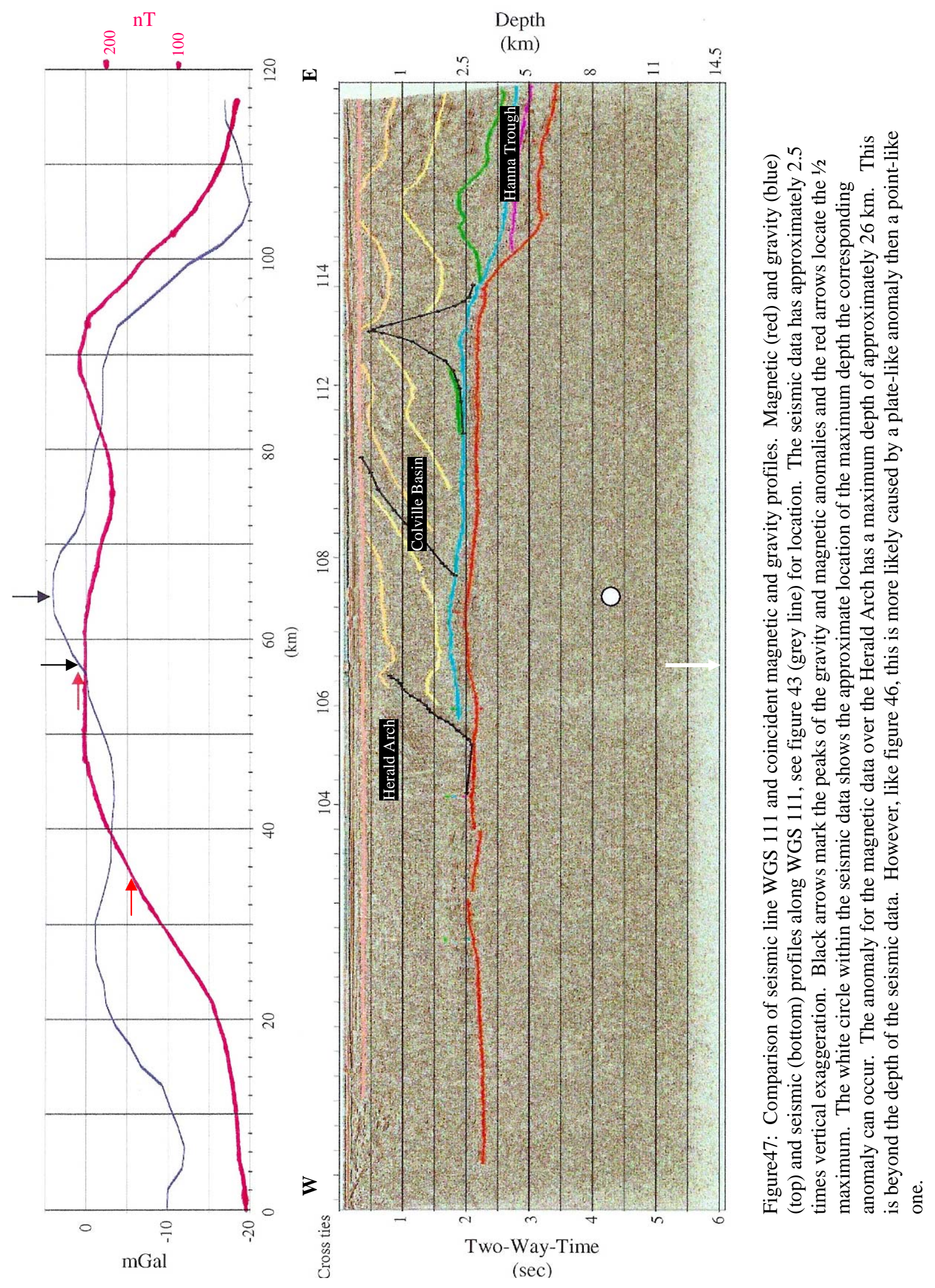




\begin{tabular}{|c|c|c|c|}
\hline LINE & $\begin{array}{c}\text { DISTANCE } \\
\text { BETWEEN PEAK } \\
\text { AND 1/2 MAXIMUM } \\
(\mathbf{K m})\end{array}$ & $\begin{array}{c}\text { DEPTH TO } \\
\text { ANOMALY } \\
\text { (CYLINDER) } \\
\text { (Km) }\end{array}$ & $\begin{array}{c}\text { DEPTH TO } \\
\text { ANOMALY } \\
\text { (SPHERE) } \\
\text { (Km) }\end{array}$ \\
\hline 5181 & 12 & $24(8.5 \mathrm{sec})$ & $24(8.5 \mathrm{sec})$ \\
\hline 112 & 11 & $22(8 \mathrm{sec})$ & $22(8 \mathrm{sec})$ \\
\hline 108 & 14 & $28(9.5 \mathrm{sec})$ & $28(9.5 \mathrm{sec})$ \\
\hline 104 & $20^{*}$ & $40(13 \mathrm{sec})$ & $40(13 \mathrm{sec})$ \\
\hline 5187 & 12 & $24(8.5 \mathrm{sec})$ & $24(8.5 \mathrm{sec})$ \\
\hline
\end{tabular}

Table 3: Table showing the estimated maximum depth to the anomaly causing the magnetic spike closest to the Herald Arch.

* Profile is very broad causing the $1 / 2$ maximum to be farther from the peak, this suggest a wider anomaly. 


\section{Chapter 6: Discussion}

Previous studies have mapped the Herald Thrust as a single linear thrust fault extending from the northwest coast of Alaska to Wrangel Island. The accompanying Herald Arch appears as a section of perched acoustic basement extending along with the thrust all the way to Wrangel Island and northeastern Russia (Moore, 2002). This study shows two faults on either side of the Herald Arch, a thrust fault to the north and a normal or possibly strike-slip fault on the south side, figure 2 . The second fault could not be confidently identified due to the poor data quality, especially just below the basement horizon of the Hope Basin. There is no seismic evidence for the southern Herald fault to be strike-slip, however the similar strike-slip Kugruk Fault to the south in the Seward Peninsula could be extended to include the southern Herald fault.

The northern thrust fault, Herald Thrust, begins to decrease in dip moving northwest going from nearly 60 degrees on line WGS 116 to 20 degrees on line WGS 106 (plates 1 and 3) and does not appear on line 102 or on the deep crust line 5187 in the

northwest parts of the study area. Reconstructions of the thrusts, not including the Herald Thrust, also follow a similar pattern of a large amount of shortening along line 116 then decreasing to the south and north. The lack of detachment and reduction in the amount of shortening that appears to have taken place in these northern sections suggests the amount of compression in this region was much less than the area closer to line 116 and the Chukchi Syntaxis.

The detachment of the Herald Thrust from the basement occurs at the western edge of the Hanna Trough for the southeastermost seismic lines. As the Hanna Trough 
becomes shallower, the dip of the thrust reduces until the western edge of the trough is no longer discernable, where there is no detachment of the thrust. This suggests a tectonic inheritance for the detachment and formation of the Herald Thrust from the older Hanna Trough.

The perched acoustic basement of the Herald Arch is visible on both sets of seismic data and follows fairly closely the " $\mathrm{L}$ "-shaped bend in the magnetic data. As the magnetic high broadens and extends to the north, the perched acoustic basement also extends farther to the north but also continues on to the west beyond line 5187. This is best seen in figure 37 which shows the basement matching up well with the magnetic data.

The maximum depth calculations suggest that the magnetic anomaly is caused by something no deeper than about 8 seconds on the seismic data. This does not exclude the Herald Arch which lies between 2 and 3 seconds deep but could also be attributed to something hidden in the basement rock. The correlation between the magnetic data and depth to basement contours suggests the magnetic highs were created as a result of the Herald Thrust. Since the rocks making up the thrust are believed to be Ellesmerian and Franklinian, not highly magnetic rocks, the thrust could have brought up magnetic bodies from the lower and middle crust, similar to the areas of the North Slope. Other large magnetic highs can be observed along the Cordilleran mobile belt, especially at key geometric points, similar to the bend to the north of the Herald Thrust. These represent areas of strong, dense crust containing large amounts of mafic material supplied by depleting the mantle of basalt (Saltus, 2007). 
The thick sedimentary fill of the Colville foreland basin suggests a source area of high topography existed in the Cretaceous where the Herald Arch and Hope Basin are located today. This high topography would have created a deep crustal root to support the height of the landmass needed to supply the delta with sediment (Klemperer, 2002). Present day the crust thins drastically starting beneath the Herald Arch and into the Hope Basin and no root is present. This thinning could be attributed to extension and differential spreading. Although the high shoulders typical of areas with the lower crust and mantle spreading at a more rapid rate then the upper crust are not present, it does not exclude this possibility. The weakened lower crust and upper mantle could have allowed the lithospheric mantle to stretch at a higher rate than that of the upper crust (Zeyen, 1996) during the creation of the Hope Basin. The timing of the thinning is difficult to constrain. The thinning could have taken place in multiple stages with the earliest occurring during the mid-Cretaceous north-south extension (Amato et al., 2002). The formation the Hope Basin in the Tertiary, would have further enhanced the initial thinning of the crust.

If the fault to the south of the Herald Arch (plates 1-3) is a strike-slip fault, it could also be an explanation for possible differential spreading. Differential movement can occur if there is impedance in the translation movement of the crust, for example a bend in the fault system (Beaudoin, 1994). The sharp bend in the Herald Thrust occurs at the location of the thinning of the crust. The bend could have prevented the upper crust from continuing to spread but allowed for the upper mantle to continue to movement and weakening the lower crust leading to additional thinning of the crust. 


\section{Chapter 7: Conclusions}

The present day Hope Basin and Herald Arch region experienced a large amount of shortening during the Cretaceous which produced a high mountain range. This range was the source area for the thick sedimentary accumulation in the Colville foreland basin. The huge thickness of the sedimentary section of the Brookian sequence deposited due to tectonic loading and direction of transport of sediment, indicates an area of high topographic relief and thus a deep crustal root. Deep seismic studies have shown the Moho to thin from over $37 \mathrm{~km}$ deep beneath the thrust to $28 \mathrm{~km}$ beneath the Herald Arch where a deep crustal root of the mountain chain should be present. The crustal root could have been removed by differential spreading, multiple extensional phases, or possibly just not have been as deep originally due to a previously thin crust due to extension (Kusznir and Matthews, 1988) although this last option appears unlikely.

The Herald Arch is bound by a dual fault system. The thrust fault to the north is the commonly mapped Herald Thrust, however it does not extend from the Lisburne Hills to Wrangel Island and beyond. The detachment thrust appears to die out to the northwest along the arch and can no longer be recognized on the seismic data on line WGS 102 (figure 30), less than $100 \mathrm{~km}$ northwest of the Lisburne Peninsula. The other fault, to the south between the Herald Arch and Hope Basin, can not be clearly identified from the seismic data used in this study. The discontinuity, visible on some of the available seismic data, shows the horizons within the Herald Arch and just beneath the Hope Basin suddenly ending with faint traces appearing below the Hope Basin. This could be a 
normal fault associated with the opening of the Hope Basin or a transverse fault that connects the Herald Thrust with the Hope Basin.

The Hope Basin alone with its maximum 9\% (Elswick, 2003) extension is less than the $30 \%$ required according to Klemperer et al. (2002). If the earlier, midCretaceous, extensional event thinned the crust, this could account for some of the missing 20\% extension missing, but in that case extension was not accompanied by basin formation.

The thinning of the crust beneath the Hope Basin and Herald Arch could be attributed to differential spreading. Since the Hope Basin is a large basin and there are no prominent shoulders, the differential spreading model which best suits this area is one which the difference in spreading rate is small. The upper crust could have spread at slower rate and experienced a smaller amount of extension during the opening of the Hope Basin than the lower crust and upper mantle but the difference in stretching was small. This depth-dependent stretching can be produced as a result of a strike-slip fault or a difference in strength.

Additional studies and new seismic surveys, particularly between the Hope Basin and Herald Arch, could reveal a clearer picture of the horizons beneath the Hope Basin and enable a clearer map of the second fault to be made. 


\section{References Cited}

Amato, J.M., Toro, J., Moore and T.E., 2004. Origin of the Bering Sea Salient: Geological Society of America Special Paper 383, p. 131-144.

Amato, J.M., Miller, E.L., Hannula, K.A., 2002. Orthogonal flow directions in the extending continental crust: An example from the Kigluaik gneiss dome, Seward Peninsula, Alaska: Geological Society of America Special Paper 360, p. 133-146.

Agena, W.F., Lee, M.W. and Hart, P.E., 2001. Reprocessing of multi-channel seismic-reflection data collected in the Chukchi Sea, USGS Open-File Report 01-330.

Barnes, A.E., 1994. Moho reflectivity and seismic signal penetration: Tectonophysics, vol. 232, p. 299307.

Beaudoin, B.C., 1994. Lower-crustal deformation during terrane dispersion along strike-slip faults: Tectonophysics, vol. 232, p. 257-266.

Beikman, H.M., 1980, Geologic map of Alaska: U.S. Geological Survey, 2 sheets, scale 1:2,500,000.

Bird, K.J. and Molenaar, C.M., 1992. The North Slope Foreland Basin, Alaska, in Macqueen, R.W., and Leckie, D.A., eds., Foreland Basins and Foldbelts: AAPG Memoir 55, p. 363-393.

Burger, H.R., 1992. Exploration Geophysics of the Shallow Subsurface. Englewood Cliffs, New Jersey: Prentice Hall, p. 317-452.

Campbell, Russel H., 1967. Areal geology in the vicinity of the Chariot Site Lisburne Peninsula, Northwestern Alaska: U.S. Geological Survey Professional Paper, p. 1-71.

Christiansson, P., Faleide, J.I. and Berge, A.M., 2000. Crustal structure in the northern North Sea: an integrated geophysical study: Geological Society Special Publications, vol.167, pp.15-40.

Cook, Frederick A., 2002. Fine structure of the continental reflection Moho: Geological Society of America Bulletin, vol 114, no. 1, p. 64-79.

Cooper, A.K., Marlow, M.S., and Scholl, D.W., 1987. Geologic Framework of the Bering Sea Crust: Geology and Resource Potential of the Continental Margin of Western North America and Adjacent Ocean Basins - Beaufort Seat to Baja California, p. 73-102.

Decker, J., Robinson, M.S., Clough, J.G., and Lyle, W.M., 1988. Geology and Petroleum Potential of Hope and Selawik Basins. Public Data-File Report. No. 88-1.

Dewey, J.F., 1988. Extensional collapse of orogens: Tectonics, Vol. 7, no. 6, p. 1123-1139.

Elswick, Virginia Lee, 2003. Seismic interpretation and structural evaluation of the Hope Basin, Alaska: Master's Thesis, West Virginia University, p. 1-21.

Grantz, Arthur and May, Steven D., 1987. Regional geology and petroleum potential of the United States Chukchi Shelf north of Point Hope: Geology and Resource Potential of the Continental Margin of Western North America and Adjacent Ocean Basins - Beaufort Sea to Baja California, p. 37-58.

Grantz, A., May, S.D. and Hart, P.E., 1994. Geology of the Arctic continental margin of Alaska: in The Geology of North America, Vol. G-1, The Geology of Alaska, p. 17-48. 
Herman, B.M. and Zerwick, S.A., 1992. A Preliminary Analysis of Potential Field Data in the Southern Chukchi Sea: Minerals Management Service, MMS 94-0040, p 301-306.

Huffman, C.A., 1985. Introduction to the Geology of the Nanushuk Group and Related Rocks, North Slope, Alaska: Geology of the Nanushuk Group and Related Rocks, North Slope, Alaska, in U.S. Geological Survey Bulletin, vol. 1614, p. 1-6.

Klemperer, S.L., Greninger, M.L., and Nokleberg, W.J., 2002. Documentation for Geographic Information Systems (GIS) Compilation of Gephysical, Geologic and Tectonic Data for the Bering Shelf, Chukchi Sea, Arctic Margin and Adjacent Landmasses: in Geological Society of America Special Paper 360:

Accompanying CD.

Klemperer, S.L., Miller, E.L., Grantz, A. and Scholl, D.W., 2002. Crustal structure of the Bering and Chukchi shelves: Deep seismic reflection profiles across the North American Continent between Alaska and Russia: Geological Society of America Special Paper 360, p. 1-24.

Kusznir, N.J. and Matthews, D.H., 1988. Deep seismic reflections and the deformational mechanics of the continental lithosphere: Journal of Petrology. Special Lithosphere Issue, p. 63-87.

Lallemant, H.G., Gotschaulk, R.R., Sisson, V.B., and Oldow, J.S., 1998. Structural analysis of the Kobuk fault zone, north-central Alaska, in Oldow, J.S. and Lallemant, H.G., eds., Architecture of the Central Brooks Range Fold and Thrust Belt, Arctic Alaska: The Geological Society of America Special Paper 324. p. 261-268.

Levander, A.R. and Holliger, K., 1992. Small-scale heterogeneity and large-scale velocity structure of the continental crust: Journal of Geophysical Research, vol.97, no.B6, pp.8797-8804

Levander, A. R., Fuis, G. S., Wissinger, E. S., Lutter, W. J., Oldow, J. S. and Moore, T. E., 1994. Seismic images of the Brooks Range fold and thrust belt, Arctic Alaska, from an integrated seismic reflection/refraction experiment: Tectonophysics, vol. 232, p. 13-30.

Macnab, R., Verhoef, J., Roest, W., Arkani-Hamed, J., 1995. New database documents the magnetic character of the Arctic and North Atlantic, Eos Trans. AGU, 76(45), 449.

Mayfield, C.F., Tailleur, I.L. and Ellersieck, I., 1983. Stratigraphy, structure and palinspastic synthesis of the Western Brooks Range, Northwestern Alaska: Geology and Exploration of the National Petroleum Reserve in Alaska, 1974 to 1982, p. 143-190.

Moore, Thomas E, Dumitru, Trevor A., Adams, Karen E., Witebsky, Susan N. and Harris, Anita G., 2002. Origin of the Lisburne Hills-Herald Arch Structural Belt: Stratigraphic, Structural, and Fission-Track Evidence From the Cape Lisburne Area, Northwestern Alaska: Geological Society of America Special Paper 360, p. 77-109.

Moore, Thomas E., Wallace, Wesley K., Bird, Kenneth J., Karl, Susan M., Mull, Charles G. and Dillon, John T., 1994. Geology of northern Alaska in The Geology of North America, Vol. G-, The Geology of Alaska, The Geological Society of America, p. 49-140.

Mull, C.G., 1985. Cretaceous Tectonics, Depositional Cycles, and the Nanushuk Group, Brooks Range and Arctic Slope, Alaska: Geology of the Nanushuk Group and Related Rocks, North Slope, Alaska, in U.S. Geological Survey Bulletin, vol. 1614, p. 7-36.

NAAMS (National Archive of Marine Seismic Surveys), 2005. http://walrus.wr.usgs.gov/NAMSS/

Natal'in, B.A., 1998. Late Cretaceous - Tertiary Deformations in the Chukotka Peninsula: Implications for the Origin of the Hope Basin and the Herald Thrust Belt (Chukchi Sea): Geotectonics, Vol 33, No. 6, p. 489-505. 
Patton, W.W. Jr. and Tailleur, I.L., 1977. Evidence in the Bering Strait Region for Differential Movement Between North America and Eurasia: Geological Society of America Bulletin, V. 88, p. 1298-1204.

Plafker, G. and Berg, H.C., 1994. Overview of the Geology and tectonic evolution of Alaska in The Geology of Alaska: p. 989-1021.

Saltus, R.W. and Hudson, T.L., 2007. Regional magnetic anomalies, crustal strength, and the location of the northern Cordilleran fold-and-thrust belt: The Geological Society of America, v. 35, no. 6, p. 567-570.

Saltus, R.W., Potter, C.J., Phillips, J.D., 2006. Crustal insights from gravity and aeromagnetic analysis: Central North Slope, Alaska: AAPG Bulletin, Vol. 90, No. 10, p. 1495-1517.

Sherwood, K.W., 2006. Structure of Hanna Trough and Facies of Ellesmerian Sequence, U.S. Chukchi Shelf, Alaska (Abstract with two posters): 2006 Joint Meeting of Colldilleran Section, Geological Society of America (GSA), Pacific Section, American Association of Petroleum Geologists (AAPG), and Alaska/Western Section of Society of Petroleum Engineers (SPE), 08-10 May, Anchorage Alaska, Geological Society of America Abstracts, Volume 38, number 5, abstract 37-2, p. 85.

Sherwood, K.W., Craig, J.D., Scherr, J., Johnson, P.P. and Cooke, L.W., 2002. Undiscovered Oil and Gas Resources of U.S. Arctic Alaska Outer Contential Shelves (abs): Poster presentation at AAPG Pacific Section, Anchorage, Alaska, May 18-23, 2002; American Association of Petroleum Geologists Bulletin, v. 87, no 6. p 1159.

Sherwood, K.W., Johnson, P.P., Craig, J.D., Zerwick. S.A., Lothamer, R.T., Thurston, D.K. and Hurlbert, S.B., 2002. Structure and stratigraphy of the Hanna Trough, U.S. Chukchi Shelf, Alaska in Geological Society of America Special Paper 360.

Sherwood, K.W., Craig, J.D., Lothamer, R.T., Johnson, P.P. and Zerwick, S.A., 1995. Chukchi Shelf Assessment Province, in Geologic Assessment 1995 National Resource Assessment Alaska Federal Offshore. U.S. Minerals Management Service, p. 115-196.

Shipley, T., Gahagan, L., Johnson, K., and Davis, M., editors, Seismic Data Center. 2005. University of Texas Institute for Geophysics. URL = http://www.ig.utexas.edu/sdc/. This page last updated: 2006-Apr-06 17:02:24.

Smith, W. H. F. and D. T. Sandwell. 1997. Global Seafloor Topography from Satellite Altimetry and Ship Depth Soundings, Science, v. 277, p. 1956-1962.

Tearpock, D.J. and Bischke, R.E., 2003. Integration of Geophysical Data in Subsurface Mapping, in Applied Subsurface Geologic Mapping with Structural Methods $2^{\text {nd }}$ edition: p. 134-174.

Thurston, D.K. and Theiss, L.A., 1987. Geologic Report for the Chukchi Sea Planning Area, Alaska: United States Department of the Interior, Mineral Management Service.

Tolson, Ralph B., 1987. Structure and Stratigraphy of the Hope Basin, Southern Chukchi Sea, Alaska: Geology and Resource Potential of the Continental Margin of Western North America and Adjacent Ocean Basins - Beaufort Sea to Baja California, p. 59-71.

Van Der Pluijm, B.A. and Marshak, S., 2004. Earth Structure: Second Edition: W.W. Norton and Company: p. 435-436.

Verhoef, J., Macnab, R., Roest, W. et al., 1996. Magnetic anomalies, Arctic and North Atlantic Oceans and adjacent land areas. Geological Survey of Canda Open File, 3282c. 
White, N. and McKenzie, D. 1988. Formation of the "Steer's Head" Geometry of Sedimentary Basins by Differential Stretching of the Crust and Mantle: Geology, Vol. 16, p. 250-253.

Wolf, L.W., McCaleb, R.C., Stone, D.B., Brocher, T.M., Fujita, K. and Klemperer, S.L., 2002. Crustal structure across the Bering Strait, Alaska: Onshore recordings of a marine seismic survery: Geological Society of America Special Paper 360, p. 25-37.

Zerwick, Susan A., 1999. Hope Basin Assessment Province: Undiscovered Oil and Gas Resources, Alaska Federal Offshore, As of January 1995, ch 15, pp 217-228.

Zeyen, H., Negredo, A. and Fernandez, M., 1996. Extension with Lateral Material Accommodation 'Active' vs. 'Passive' rifting: Tectnophysics, Vol. 266, p.121-137. 


\title{
Appendix
}

\author{
Stratified Sedimentary Sequence of Alaska \\ Mainly marine, includes some volcanic rocks and in part metamorphosed \\ See figure 10 for locations. Modified from Beikman, (1980)
}

Qh HOLOCENE DEPOSITS-Alluvial, glacial, lake, estuarine, swamp, landslide, flood plain, and beach deposits

Q QUATERNARY DEPOSITS—Alluvial, glacial, lake, eolian, beach, and volcanic deposits. Includes the marine

Bootlegger Cove Clay

T TERTIARY ROCKS - Sedimentary rocks concealed beneath Quaternary cover on Point Hope and volcanogenic sedimentary rocks and flows, dikes, and sills on the Alaska Peninsula and Umnak Island

uK UPPER CRETACEOUS ROCKS-Shale, sandstone, and conglomerate of the Ninuluk Formation of the Nanushuk Group and Seabee and Schrader Bluff Formations of the Colville Group in the Arctic Coastal Plain and Foothills; nonmarine and marine clastic rocks, siltstone, and shale of the Chignik and Hoodoo Formations on the Alaska Peninsula; graded beds of sandstone and slate of the Kodiak Formation on Kodiak and Afgonak Islands; sandstone and mudstone of Shumagin Formation on Shumagin and Sanak Islands

IK LOWER CRETACEOUS ROCKS-Graywacke, sandstone, shale, siltstone, and conglomerate of part of the Tiglukpuk Formation of former usage, Okpikruak, Fortress Mountain, Torok, and Kukpowruk Formations in the western Arctic Foothills; the Kongakut Formation, Bathtub Graywacke, and Tuktu and Grandstand Formations in the eastern Brooks Range and Arctic Foothills; unnamed graywacke, argillite, conglomerate, and minor limestone southeast of the mouth of the Kuskokwim River; interlayered submarine and subaerial andesitic fragmental volcanic rocks, flows, tuffs, and volcaniclastic rocks of the Chisana Formation north of the Wrangell Mountains; and unnamed graywacke, argillite, and minor andesite on Etolin Island

KJ CRETACEOUS AND JURASSIC ROCKS-Argillite, shale, graywacke, quartzite, conglomerate, lava, tuff, and agglomerate. Almost barren of fossils and probably includes rocks ranging in age from Early Jurassic to Late Cretaceous. In places moderately to highly metamorphosed (amphibolite facies)

TrP TRIASSIC AND PERMIAN ROCKS—Sandstone, siltstone, and shale of the Sadlerochit Group on the north flank of the Brooks Range; mafic volcanic rocks, red beds, limestone, and calcareous argillite in the Chulitna River area; argillite, limestone, siltstone, conglomerate, and abundant gabbroic sills in the east-central Alaska Range where it includes the upper part of the Mankomen Group; and schist, graywacke, slate, conglomerate, phyllite, andesite flows and tuffs on Admiralty Island where it includes the Barlow Cove Formation

JP JURASSIC, TRIASSIC, AND PERMIAN ROCKS-Shale, siltstone, and chert and graywacke in the Brooks Range. Includes upper part of Nuka Formation and Siksikpuk and Shublik Formations

$\mathrm{MzPz}$ MESOZOIC AND PALEOZOIC ROCKS-Sandstone, shale, chert, dolomite and conglomerate, in a discordant rock sequence of unknown provenance that includes rocks of Mississippian, Triassic, Jurassic, and Cretaceous age in the western Brooks Range (includes Nuka Formation); Lower Jurassic, Pennsylvanian, and Permian rocks, in part covered by Tertiary sedimentary rocks and intruded by granitic rocks of Tertiary age in north-central Chugach Mountains; and slate, quartzite, schist and phyllite with interlayered beds of marble, layered gneiss and amphibolite of Ordovician to Jurassic or Cretaceous age along the west flank of the Coast Mountains

M MISSISSIPPIAN ROCKS - Conglomerate, shale, limestone with subordinate chert and dolomite of the Kekiktuk Conglomerate and Kayak Shale of the Endicott Group and the Utukok Formation and Wachsmuth and Alapah Limestones of the Lisburne Group on the northern flank of the Brooks Range. Limestone, dolomite, and interbedded chert of the Iyoukeen Formation on Chichagof Island and Peratrovich Formation on Prince of Wales Island

JM JURASSIC TO MISSISSIPPIAN ROCKS-Unnamed slate and quartzite northwest of Porcupine River and Lisburne and Sadlerochit Groups and Kingak Shale at northeast front of Brooks Range

MD MISSISSIPPIAN AND (OR) DEVONIAN ROCKS-Sandstone, graywacke, quartzite, and conglomerate. Includes the Noatak Sandstone in western Brooks Range and Kekiktuk and Kanayut Conglomerates in eastern Brooks Range

$\mathrm{uD}$ UPPER DEVONIAN ROCKS - Shale, sandstone, chert, conglomerate, and quartzite in eastern and central Brooks Range and limestone and dolomite in western Brooks Range. Includes Hunt Fork Shale, Kanayut Conglomerate, Kugururok Formation, and Eli Limestone (Middle and Upper Devonian) 
umD UPPER AND (OR) MIDDLE DEVONIAN ROCKS-Conglomerate, graywacke, phyllite, shale, sandstone, siltstone, and limestone. Includes Nanook Limestone in Shublik Mountains

DS DEVONIAN AND SILURIAN ROCKS — Limestone, dolomite, marble, and shale of the Katakturuk Dolomite and the Skajit Limestone in Brooks Range and Karheen Formation in Prince of Wales Island

IPz LOWER PALEOZOIC ROCKS-Includes rocks of Cambrian through Devonian age, in places metamorphosed to greenschist and amphibolite facies. Sedimentary rocks include limestone, dolomite, argillite, chert, and graywacke and metasedimentary rocks include schist, quartzite, slate, greenstone, carbonate rocks, and phyllite. Includes Holitna Group in Kuskokwim mountains, Tonzona Group along Kuskokwim River, rocks formerly included in Birch Creek Schist in YukonTanana Upland, unmetamorphosed rocks of the Funnel Creek, Adams, Hillard, Road River, McCann Hill and Hillard Formations, and Puppets Formation on Gravina and Annette Islands

IPzpC LOWER PALEOZOIC AND (OR) PRECAMBRIAN ROCKS—Sandstone, limestone, shale, chert, phyllite, argillite, and quartzite of the Neruokpuk Formation in the northeast Brooks Range; quartzmica schist, mafic greenschist, calcareous schist, chlorite schist, phyllite and quartzite along south flank of Brooks Range and southwest through Kokrine-Hodzana Highlands; schist and quartzite of the Birch Creek Schist of former usage in Yukon-Tanana Highlands; highly metamorphosed clastic rocks including the Keevy Peak Formation in the north flank of the Alaska Range; and volcanogenic greenschist with interstratified marble in Prince of Wales, Long and Dall Island, where it includes the Wales Group and possibly Descon Formation

\section{CONTINENTAL DEPOSITS}

uKc UPPER CRETACEOUS CONTINENTAL DEPOSITS—Sandstone and conglomerate and interbedded shale, clay, silt, and bentonite of the Niakogon Tongue of the Chandler Formation of the Nanushuk Group and the Prince Creek Formation of the Colville Group on the Arctic Coastal Plain; shale and siltstone in the Yukon-Koyukuk basin; and pebble conglomerate around the margins of the basin

1Kc LOWER CRETACEOUS CONTINENTAL DEPOSITS—Shale, claystone, siltstone, sandstone, conglomerate, coaly shale and coal, ironstone, and bentonite. Includes Corwin Formation (Lower and Upper Cretaceous) of the Nanushuk Group and Killik Tongue of Chandler Formation of Nanushuk Group on Arctic Coastal Plain

\section{VOLCANIC ROCKS}

uKvf UPPER CRETACEOUS FELSIC VOLCANIC ROCKS - Rhyolite to dacite

IKvi LOWER CRETACEOUS INTERMEDIATE VOLCANIC ROCKS - Trachyte to andesite

lKv LOWER CRETACEOUS UNDIFFERENTIATED VOLCANIC ROCKS

JPvm JURASSIC, TRIASSIC, AND PERMIAN MAFIC VOLCANIC ROCKS - Basalt

vf $\quad$ FELSIC VOLCANIC ROCKS, AGE UNKNOWN - Rhyolite to dacite

\section{INTRUSIVE ROCKS}

uKii UPPER CRETACEOUS INTERMEDIATE INTRUSIVE ROCKS - Syenite to diorite

Kif CRETACEOUS FELSIC INTRUSIVE ROCKS - Granite to granodiorite

IPzim LOWER PALEOZOIC MAFIC INTRUSIVE ROCKS - Gabbro

im MAFIC INTRUSIVE ROCKS, AGE UNKNOWN - Gabbro

\section{ULTRAMAFIC ROCKS}



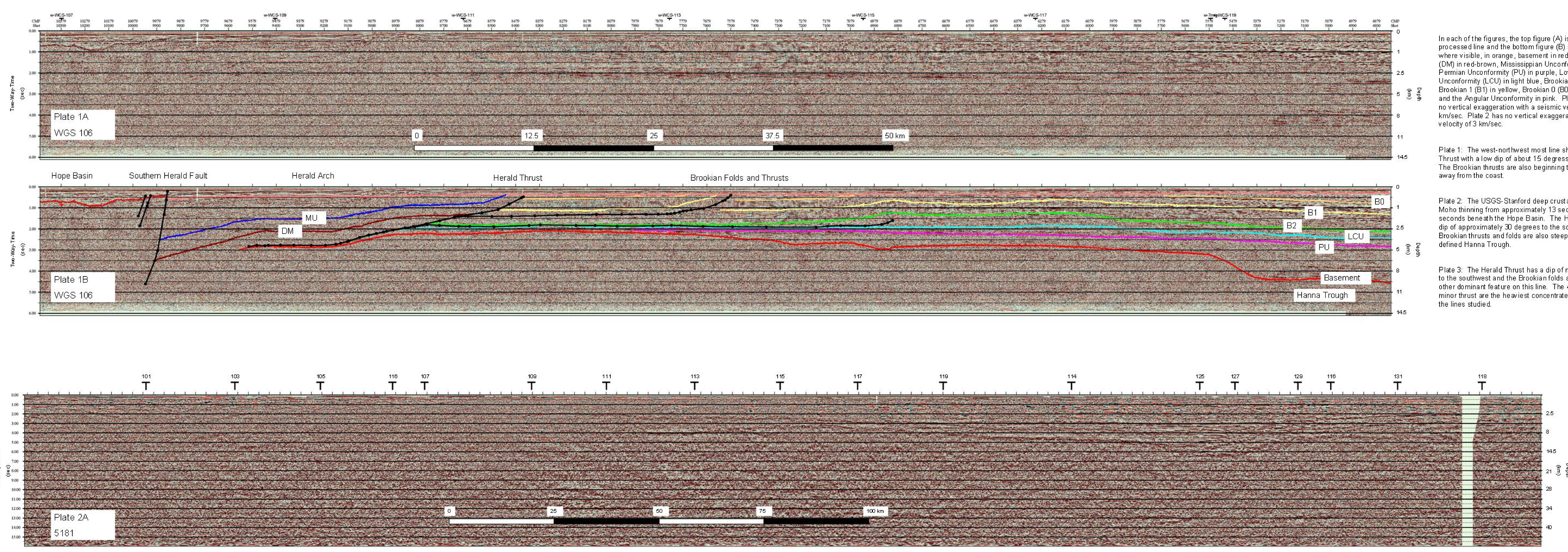

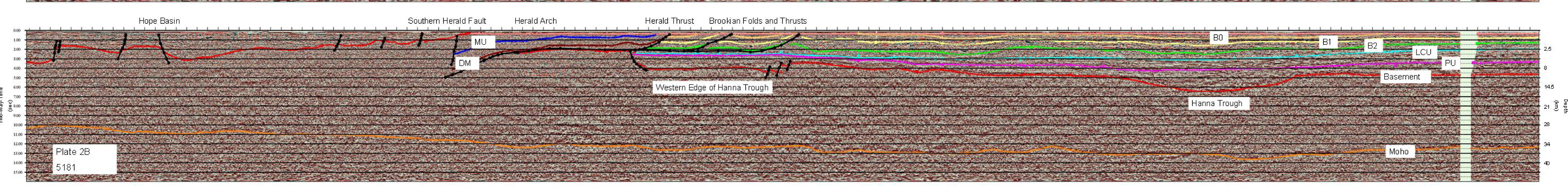
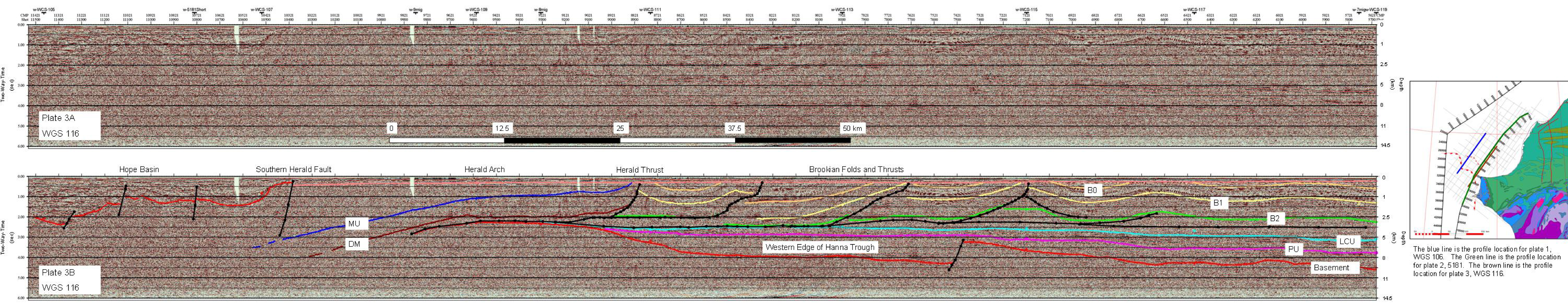